\title{
THE VERTICAL FARM - Architectural Design Principles
}

$\begin{aligned} \text { Authors: } & \text { Bujar Q. Bajçinovci } \\ \text { Submitted: } & \text { 5. November } 2017 \\ \text { Published: } & 6 \text {. November } 2017 \\ \text { Volume: } & 4 \\ \text { Issue: } & 5 \\ \text { Affiliation: } & \text { University of Prishtina, Faculty of Civil Engineering and } \\ & \text { Architecture, Kosovo } \\ \text { Keywords: } & \text { Vertical farm, Design Principles, Textbook, Monograph, } \\ & \text { Language: Albanian } \\ \text { DOl: } & \text { 10.17160/josha.4.5.354 }\end{aligned}$




\title{
THE VERTICAL FARM
}

\section{ARCHITECTURAL DESIGN PRINCIPLES}

\begin{abstract}
This book is originally and especially dedicated to the students of Architecture Department of the University of Prishtina for Educational, and Not-for-profit purposes. The monograph incorporates contemporary knowledge of the Vertical Farm Architectural Design Principles, followed by discussion, extracts, quotes and citations by various authors, as well as official government publications as the academic comparative references. Seeing the lack of literature in the field of Architecture, especially in Albanian language, I was inspired by the research and writing this monograph, which elaborates the Vertical Farm - Architectural Design Principles. The book is a free and not-for-profit purposes, it is intented as basic literature of Master courses which I taught at University of Prishtina. In the monograph I have reflected my personal professional experience and literature review I have consulted so far. There are four chapters, each chapter extensive explain and discuss issues related to the specific topic of the Vertical Farm - Architectural Design Principles.
\end{abstract}

\section{Prof.Ass.Dr. BUJAR BAJÇINOVCI Dipl.Ing.Arch. Faculty of Civil Engineering and Architecture University of Prishtina, Kosovo.}

\section{Prishtinë 2017}


FERMAT VERTIKALE - PARIMET PROJEKTUESE ARKITEKTONIKE. 2017.

Bujar Bajçinovci. Faqe: 95

Recensuës:

Prof.Dr. Behxhet MUSTAFA

Prof.Dr. Islam FEJZA

Falënderim i posaqëm për recensuesit, që patën konsideratë për ta lexuar monografinë, të cilët më kanë ndihmuar gjatë shkruarjes dhe finalizimit të kësaj monografie. Konsiderojë se pa këtë kontribut, kjo monografi nuk do të ishte ashtu siq është. Po ashtu falënderim të posaqëm kolegëve për sygjerime dhe për përkrahjen për ta botuar këtë monografi.

Bujar Bajçinovci @. Attribution-NonCommercial 4.0 International (CC BY-NC 4.0). This book is licensed under a ( Creative Commons Attribution-NonCommercial 4.0 International License. ) license. See the license for more details: You can share this book as long as you credit the author, and don't use for the commercial purposes, and do make it available to everyone else under the same terms.

Copyright, Autori/Author. Prof.Ass.Dr. Bujar Bajçinovci Inxh.Dipl.Ark. 2017.

Mësimdhënës, Katedra e Projektimit

Fakulteti i Ndërtimtarisë dhe Arkitekturës

Universiteti i Prishtinës

Tetor, 2017

Kopërtina. Bujar Bajçinovci

Photo: Megastructure, Detroit. (CC BY 2.0)

Source: Paul Bica, July/2009. Flickr. Licensed: Creative Commons Attribution 2.0 Generic. 


\section{FERMAT VERTIKALE}

PARIMET PROJEKTUESE ARKITEKTONIKE

MONOGRAFI SHKENCORE

NGA LEMIA E PROJEKTIMIT ARKITEKTONIK

\section{FERMAT VERTIKALE}

PARIMET PROJEKTUESE

BUJAR BAJÇINOVCI

Prishtinë 2017 


\section{PARATHËNIE}

Monografia fillimisht i'u dedikohet studentëve të Arkitekturës, me njohuri bashkëkohore profesionale dhe shkencore nga lëmia e projektimit të fermave vertikale. Për më tepër, shpresoj që këtë libër ta gjejnë si udhëzues edhe profesionistët e lëmisë së Arkitekturës dhe Inxhinierisë së ndërtimit. Monografia në vete ngërthen njohurit bashkëkohore të lëmisë së projektimit të fermave vertikale, duke u përcjellë me diskutim, ekstrakte, pjesë dhe citime nga autor të ndryshëm, si dhe publikime zyrtare qeveritare në cilësi të referencave krahasuese. Duke parë mungesën e literaturës në lëminë e Arkitekturës, kjo monografi paraqet dhe plotëson mungesën e literaturës shkencore, duke prezantuar parimet e projektimit, konceptin e të kuptuarjes së procesit të projektimit të fermave vertikale, të udhëhequr nga: standardet, rregulloret, udhëzimet administrative si dhe mendësisë filozofike e të krijuarit arkitektonik. Ky libër ka për qëllim të shërbejë si udhëzues praktik për njohjen e procesit të projektimit arkitektonik, konceptin e ndërtimit dhe të funksionit të tërësisë së fermave vertikale.

Agroindustria dhe kultivimi i bimësisë në shekullin e XX kanë pësuar transformime kardinale duke ju falënderuar zhvillimit të shkencës, teknikologjisë, rritjes së bazës materiale - ekonomike të shoqërisë, si dhe të rritjes së standardit jetësor të njeriut. Agroindustria si pjesë e industrisë sot si aktivitet dytësor ekonomik përfaqësohet me $30 \%$ të prodhimit. Projektimi i fermave vertikale shfaq sfida urbane dhe kompozicionale, sidomos, kur procesi i prodhimit nënkupton përdorimin e pajisjeve të ndryshme teknologjike të cilat janë pak të njohura. Diversiteti i projektimit të fermave vertikale duhet përherë të jetë në përputhje me kërkesat e proceseve teknologjike, zhvillimin ekonomik, mbrojtjes së ambientit dhe zhvillimit të qëndrueshëm shoqëror. Sigurisht që, nuk është e mundur për të trajtuar të gjitha detajet e tematikës dhe fushës së shtjelluar, mirëpo, qëllimi kryesor i kësaj monografie është që të promovojë njohuri themelore projektuese në fushën e shkoqitur, dhe kështu të inkurajojë për t'u konsultuar me specialistët të cilat kanë ekspertizën e nevojshme në projektimin e fermave vertikale komerciale. Pjesa më e madhe në këtë libër sqaron standarde në lidhje me kërkesat e larta teknike, organizative dhe ekonomike. Këto standarde dhe normativa kanë të bëjnë kryesisht me komplekset prodhuese në relacion me planifimin urban si dhe të ndërlidhjes me struktura të tjera të modalitetit të përzier arkitektonik.

Prof.As.Dr. Bujar Bajçinovci Ing. Dipl. Ark.

Katedra e Projektimit

Fakulteti i Ndërtimtarisë dhe Arkitekturës

Universiteti i Prishtinës

Tetor, 2017 
PËRMBAJTJA :

FERMAT VERTIKALE

PARATHËNIE

PËRMBAJTJA

SHKURTESAT - PËRKUFIZIMET

INDEKSI I SHKURTESAVE

FALENDERIM

I: HYRJE

II : BUJQËSIA

\subsection{PËRDORIMI I TOKËS BUJQËSORE}

2.1.1 Çmimet e inputeve bujqësore

2.1.2 Struktura e fermave

2.1.3 Agroindustria

2.1.4 BPV në sektorin e bujqësisë dhe pylltarisë

2.1.5 Drithërat

2.1.6 Perimet

2.1.7 Pemët dhe vreshtat

2.1.8 Vreshtat

2.1.9 Kulturat foragjere dhe drithërat e gjelbërta

2.1.10 Kulturat industriale

2.1.11 Gjedhët

2.1.12 Shpeztaria

III : FERMAT VERTIKALE

3.1 KONCEPTET DHE PARIMET

3.2 SFIDAT URBANE - ARKITEKTONIKE

3.2.1 Kërkesat - Popullata

3.2.2 Racionalizimi i kultivimit bujqësor

3.3 FERMAT VERTIKALE - PARIMET PROJEKTUESE

3.3.1 Konceptet kompozicionale të fermave bashkëkohore urbane

3.3.2 Ndryshimet klimatike

3.3.3 Sistemet e kultivimit të bimësisë në fermat vertikale

3.3.3.1 Fermat me sistem Aeroponics

3.3.3.2 Fermat me sistem Hydroponics

3.3.3.3 Fermat me sistem Aquaponics

3.3.4 Strukturat kompozicionale arkitektonike - fermat vertikale

IV : MEGASTRUKTURAT HIBRIDE

4.1 HIBRIDIZIMI

4.1.1 Harmonia simbiotike, ndërtesa dhe mjedisi 
4.1.2 Ndërtesat me kohë të plotë të funksionimit

4.1.3 Strukturat, simbiozë në vertikale dhe horizontale

4.1.4 Ndërtesa hibride me funksione dhe qëllime komplekse, dinamike.

4.1.5 Ndërtesa hibride - kompozicionet komplekse, adaptive dhe dinamike.

\subsection{MATERIALET PËR SISTEMET KONSTRUKTIVE}

4.2.1 Strukturat konstruktive nga beton armea

4.2.2 Strukturat konstruktive nga çeliku

4.2.3 Strukturat konstruktive nga druri i lameluar 


\section{SHKURTESAT - PËRKUFIZIMET}

\section{Agrolndustri:}

Agroindustri, nënkupton degën e industrisë e lidhur me kultivimin e agrokulturave, si dhe shërbimet e ndërlidhura brenda një ekonomie.

\section{Rrugë publike:}

Nënkupton sipërfaqen me rëndësi të përgjithshme për komunikacion, e cila mund të shfrytëzohet nga pjesëmarrësit në komunikacion sipas kushteve të shpallura nga organi kompetent

\section{Autoudhë:}

Nënkupton rrugën publike posaçërisht të ndërtuar dhe destinuar vetëm për lëvizjen e mjeteve motorike, e cila është e shënuar me shenjë të posaçme komunikacioni, e cila ka sipërfaqe qarkulluese të ndarë fizikisht për lëvizje nga drejtime të kundërta të shiritave me gjerësi së paku 3,5 metra, varësisht nga konfiguracioni i terrenit, me nga një shirit për ndalje emergjente në të dy anët e autostradës, me gjerësi së paku 2,5 metra.

\section{Rrugë nacionale:}

Nënkupton rrugën publike zyrtarisht të kategorizuar si rrugë nacionale, e cila lidh dy e më tepër qytete dhe e cilat mund të shërbej si lidhje me rajonet jashtë Kosovës

\section{Ndërtim:}

Nënkupton ngritje, instalim, zhvendosje, riparim, zgjerim, ndryshim, shndërrim ose demolim i ndërtimeve, përfshirë ndërtesat, infrastrukturën, ndihmesat vizuale, ndihmesat tjera duke përfshirë punët për mirëmbajtjen e ndërtimeve ekzistuese. 


\section{INDEKSI I SHKURTESAVE}

ABEF

AEA

AFK

AFP

AKP

AM

APK

ASK

AUV

AZHB

BE

BPV

CEFTA

DK

DMKE

DPBT

DPZHR

DSHKT

FAO

FMN

GHG

GLV

GP

GS

ha

IBK

IKSHP

KRK

LLEB

LUV

MBPZHR

mil.

$\mathrm{MMPH}$

$\mathrm{MSH}$

MTI

OBT

PZhR

SIPK

SSHTB

SZHL
Anketa e buxhetit të ekonomive familjare

Agjencia Evropiane për Ambient

Agjencioni për Financim në Kosovë

Anketa e Fuqisë Punëtore

Agjencioni Kosovar i Privatizimit

Autoriteti Menaxhues

Agjencia Pyjore e Kosovës

Agjencioni i Statistikave të Kosovës

Agjencioni i Ushqimit dhe Veterinarisë

Agjencia për Zhvillimin e Bujqësisë

Bashkimi Evropian

Bruto Produkti Vendor

Marrëveshja për tregti të lirë me vendet e Evropës Qendrore

Drejtoritë Komunale

Drejtoria për menaxhimin me kafshët e egra dhe Ekotorizmi

Departamenti i Politika Bujqësore dhe Tregjeve

Departamenti i Politikave të Zhvillimit Rural

Departamenti i Shërbimeve Këshillimore Teknike

Food and Agriculture Organization, UN

Fondi Monetar Ndërkombëtar

Green Haus Gas/Gazra serrë

Grupe Lokale të Veprimit

Grup Punues

Gazra serrë

hektar

Instituti bujqësor i Kosovës

Instituti Kombëtar i Shëndetësisë Publike

Kreditimi Rural i Kosovës

Llogaritë Ekonomike për Bujqësi

Laboratori i Ushqimit dhe Veterinës

Ministria e Bujqësisë, Pylltarisë dhe Zhvillimit Rural

milion

Ministria e mjedisit dhe planifikimit hapësinor

Ministria e Shëndetësisë

Ministria e Tregtisë dhe Industrisë

Organizata Botërore e Tregtisë

Plani i Zhvillimit Rural

Sistemit Informativ për Pyjet e Kosovës

Sipërfaqja e Shfrytëzuar e Tokës Bujqësore

Strategjia Zhvillimore Lokale 


\section{FERMAT VERTIKALE - PARIMET PROJEKTUESE \\ Bujar Bajçinovci, 2017. Faqe 92.}

Monografia trajton njohuritë profesionale dhe shkencore nga lemia e projektimit të fermave vertikale, e cila ngërthehet nga teoria e projektimit, agroindustrisë, shëndetit publik dhe parimeve ekologjike në arkitekturë. Secili kapitull, pasqyron detajet teknike të projektimit duke u ilustruar me fotografi, vizatime dhe raste studimore. Monografia përveç se plotëson një mungesë jo të vogël shkencore në literaturën bazike universitare, ajo në veçanti përshkruan konceptet e planifikimit dhe projektimit të megastrukturave hibride.

Monografia i'u dedikohet bashkëshortes Mire, djemve Bard \& Uliks. 
HYRJE

KJO FAQE ËSHTË LËNË QËLLIMISHT E ZBRAZËT! 


\section{HYRJE}

$\mathrm{M}$ onografia shtjellon dhe ofron udhëzime praktike për lëminë e projektimit, respektivisht të komplekseve bujqesore. Qëllimi është për të prezantuar kriteret, udhëzimet dhe standardet e projektimit që janë të përdorshme dhe të aplikueshme në praktikë. Udhëzimet projektuese janë po aq të përshtatshme si për përdorim nga studentët e arkitekturës, po ashtu edhe për projektantët, në raste konkrete praktike. Monografia përcillet me skema konkrete funksionale organizative si dhe me normativa projektuese.

Projektimi arkitektonik përballet me sfida të mëdha, si rezultat i ndryshimeve evidente klimatike si dhe shprehive krejtësisht të reja të jetesës, kurse, globalizimi përshkruhet si një proces në të cilin ekonomitë rajonale, shoqëritë dhe kulturat, integrohen përmes një rrjeti global të ideve politike, komunikimit, transportit dhe vlerës integrale të tregut global. Fenomeni i globalizimit është një proces i pandalshëm historik i cili reflekton me rinovimet përkatëse teknologjike, shkencës, strategjive të reja ekonomike dhe ekologjike. Gjersa, kulturat e lashta, duke mos përdorur fjalën "ekologji" kanë ndërtuar me ekologjinë në mendësi, në të kundërtën injorimi do të sillte shkatërrim, epidemi, uri dhe shpërbërje shoqërore e klasore (Bajçinovci, 2017).

Kosova ka një sipërfaqe prej 10,908 km2, ku aktualishtë jetojnë 1,771,604 ${ }^{1}$ banorë. Vlersohet se $60 \%$ e popullatës jeton në zonat rurale. "Pjesëmarrja e bujqësisë në bruto produktin vendor në vitin 2015 ishte $10.3 \%$. Sipas rezultateve të Regjistrimit të bujqësisë të vitit 2014, ekzistojnë 130,775 ekonomi bujqësore ku janë të angazhuar 86,620 persona me orar të plotë pune. Procesi i zhvillimit rural në të gjitha vendet është i strukturuar në kuadër të planit të zhvillimit kombëtar, ku zakonisht bujqësia përfaqëson një ndër aktivitetet dominuese ekonomike në zonat rurale, që kontribuon në rritjen e prodhimit duke siguruar mallra edhe për eksport. Mirëpo, bazuar në analizat sektoriale rrjedh se për shkak të madhësisë së vogël të fermave, sistemit jo të avancuar të menaxhimit, pajisjeve të vjetëruara dhe pamundësisë së investimit në teknologji bashkëkohore të prodhimit me mjete vetanake, vetëm një numër i vogël i fermave kanë potencial të jenë konkurruese me çmimet e tregut në rajon e më gjërë. Duke pasur parasysh madhësinë e vogël të fermave duhet të gjenden forma për nxitje të bashkëpunimit mes prodhuesve përmes fuqizimit të shoqatave dhe forcimit të rolit të koperativave Bujqësore ku fermerëve u mundësohet kontraktimi i prodhimit në zingjirin e tregut përmes kontratave të furnizimit. Kjo formë e bashkëpunimit mundëson të ardhura të sigurta përmes çmimit garantues, përmirësimin e konkurrueshmërisë, marketingun, përmirësimin e cilësisë si dhe standardet e higjienës.

Gjithashtu produkti mund të ruhet më gjatë në depot ruajtëse, dhe si rezultat produkteve vendore do të jenë të pranishme në tregjet tona për një periudhë më të gjatë kohore si dhe do të ketë mundësi më e madhe për eksportin e tyre ...

1 ASK, Vlerësimi, Popullsia e Kosovës 2015. 
"Procesi i zhvillimit rural nuk mund të bëhet pa një zhvillim edhe të aktiviteteve tjera jo bujqësore në zonat rurale. Këto aktivitete kanë për qëllim krijimin e të ardhurave shtesë për përmirësim të standardit jetësor dhe reduktim të varfërisë, duke krijuar kushte të përshtatshme socio-ekonomike për parandalimin e migrimit fshat-qytet për banorët që jetojnë në viset rurale. Edhe pse kohët e fundit ka pasur investime në infrastrukturë, makineri dhe teknologji moderne, popullata rurale në Kosovë përballet me vështërsi të ndryshme. Njëra ndër vështirësitë me të cilat fermerët ballafaqohen në vazhdimësi është qasja në kredi, e që është njëra ndër burimet kryesore të financimit për investime të reja apo për zgjërimin e aktiviteteve bujqësore dhe fuqizimin e tyre. Familjet rurale në Kosovë karakterizohen në përgjithësi me qasje më të dobët në infrastrukturë rrugore, që është pengesë në qasjen e tyre në tregje, furnizim me ujë të pijshëm, pastrimin e ujërave të zeza dhe shumë pengesa tjera. Gjithashtu furnizimi me energji në shumë zona rurale është jo i qëndrueshëm. Në gjendje më të rëndë janë banorët që ende jetojnë në zona të thella malore ku për shkak të mungesës së infrastrukturës popullata është e detyruar që të migroj për gjetjen e një vendi më të përshtatshëm për jetesë. Për avansimin e vazhdueshëm në përmirësimin e kushteve në vendbanimet në vitin 2015 janë ndarë 23 mil. $€$ buxhet për subvencionimin e kategorive të caktuara nga prodhimtaria bimore, blegtorale dhe kategori tjera, si dhe 20 mil. $€$ për grante investive. Në bazë të përparësive krahasuese që Kosova ka në disa sektorë dhe kërkesave të tyre për përafrim me standardet e BE-së masat që dalin nga PZHR përqendrohen në përkrahjen e investimeve në sektorët: pemë, perime, qumësht, mish, rrush dhe verë. Falë kësaj mbështetje dhe investimeve vetanake disa kompani të industrisë ushqimore kanë rritur kapacitet e prodhimit, duke arritur që ti plotësojnë standardet e BE-së për higjienë dhe siguri të ushqimit. Kjo u ka mundësuar eksportimin e produkteve të tyre edhe në vendet e BE-së, në regjion dhe në shumë vende tjera të botës. Numri i këtyre kompanive është duke u rritur çdo ditë e më tepër. Si masë e dobishme për industrinë ushqimore është konsideruar masa e ndërmarrë nga MF si pako e dytë fiskale për përkrahjen e bizneseve për lirimin nga pagesa të lëndës së parë. MBPZHR krijon mjedis mbështetës edhe për nxitjen, fuqizimin e vlerave natyrore (trashëgimisë natyrore) në nivel kombëtar, duke promovuar ekoturizmin që rrjedh nga Plani për Bujqësi dhe Zhvillim Rural 2014-2020, boshti 2 "Mjedisi", në kuadër të cilit janë paraparë masa për përmirësimin e menaxhimit të resurseve natyrore, masa për divesifikimin e fermave dhe aktivitetet alternative si dhe masa për përmirësimin e infrastrukturës rurale në ruajtjen e trashëgimisë natyrore dhe kulturore në zonat e thella malore-rurale. Kjo është duke u arritur edhe përmes inicimit të zhvillimit të ndërrmarrjeve të vogla përpunuese, shërbime hoteliere dhe forma tjera të aktiviteteve jo bujqësore" (Ekstrakt). ${ }^{2}$

Tabela 1. Pjesëmarrja në \% e sektorit të energjisë dhe lëndëve të para në krijimin e BPV (Burimi): Muhamet Sadiku; "Sistemi ekonomik dhe zhvillimi i Kosovës", Riinvest, Prishtinë, 1997.

\begin{tabular}{l|rrr} 
Komplekset industriale & 1980 & 1985 & 1988 \\
\hline Energjetika & 21.2 & 22.3 & 19.2 \\
\hline Lëndët e para & 32.9 & 31.7 & 35 \\
\hline Sektorët përpunues & 45.9 & 56 & 45.8
\end{tabular}

2 MBPZHR. 2016, Raporti i Gjelbër i Kosovës, Prishtinë 2016 
"Vështruar nga aspekti historik, industria e Kosovës ka kaluar nëpër faza të ndryshme të zhvillimit të vet dhe në varësi të plotë me sistemin ekonomik dhe modelet e zhvillimit të ish - Jugosllavisë, me mbizotërim të pronës shoqërore dhe të qeverisjes së qendërzuar në ekonomi. Në përgjithësi, zhvillimi industrial i Kosovës ishte i bazuar në eksploatimin e lëndëve të para dhe përpunimin tyre deri në një shkallë të caktuar, por jo edhe në shkallë të kënaqshme të përpunimit dhe finalizimit"(Ekstrakt) ${ }^{3}$

Tabela 2. Indikatorët e industrializimit / pjesëmarrja e industrisë në krijimin e BPV (Burimi): Aktivitetet dhe zhvillimi demokratik i Kosovës, Riinvest, 1997.

\begin{tabular}{l|rrrrr} 
& 1971 & 1975 & 1980 & 1989 & 1994 \\
\hline Industria & 33.3 & 36.5 & 36.8 & 47.4 & 32.3 \\
\hline Bujqësia & 28.2 & 23.8 & 18.6 & 20.4 & 35.4 \\
\hline Veprimtaritë tjera & 38.5 & 39.7 & 45 & 32.2 & 32.3
\end{tabular}

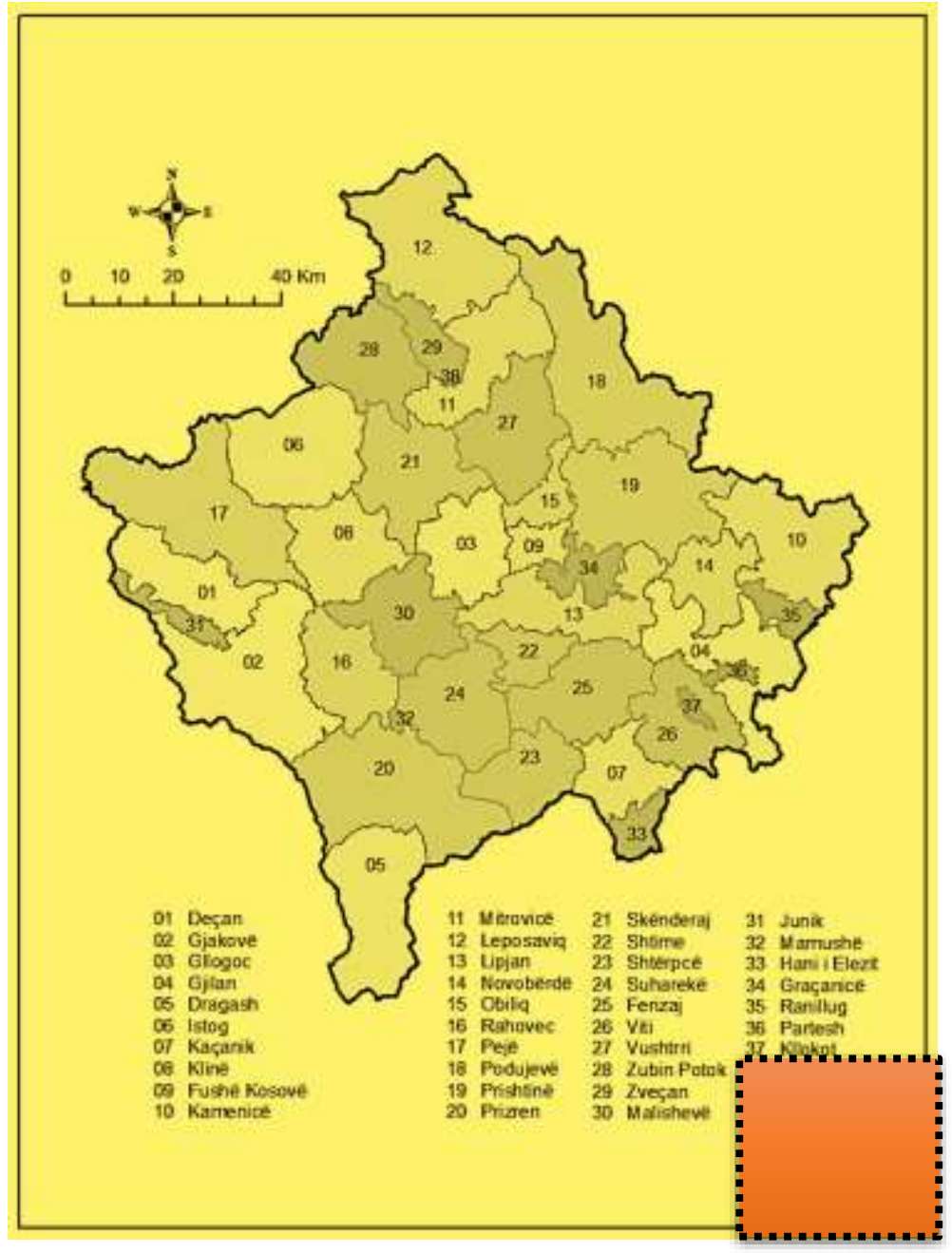

Figura 1. Harta e komunave të Kosovës (Burimi): RKS. Qeveria

3 MIT. 2009, Strategjia e industrisë së Kosovës 2009 - 2013. 
HYRJE

KJO FAQE ËSHTË LËNË QËLLIMISHT E ZBRAZËT! 


\section{BUJQËSIA}

\subsection{PËRDORIMI I TOKËS}

Teksti i mëtejmë për këtë kapitull është marrë në trajtë të ekstrakteve të shkoçitura nga publikimi zyrtar i MBPZHR: Raporti i Gjelber 2016, i përpunuar në cilësi të informatave dhe të dhënave zyrtare nga ministria përkatëse dhe ASK për nevoja të studentëve. "Përdorimi i tokës bujqësore karakterizohet nga format e shfrytëzimit, aktivitetet dhe inputet që njerëzit i ndërmarrin në përdorimin e tokës për të prodhuar, ndryshuar, për të ruajtur ose konzervuar atë. Të dhënat për përdorimin e tokës bujqësore janë shumë të rëndësishme pasi që mundësohet një parashikim për prodhimin bujqësor dhe sigurinë e ushqimit, paralajmërim i hershëm për sigurimin e ushqimit, dhe gjendjen reale për mundësinë e prodhimit në bujqësi. Posedimi i këtyre të dhënave çon drejt krijimit të politikave të qëndrueshme bujqësore Gjithsej sipërfaqja e tokës që shfrytëzohet në Kosovë është 512,000 ha tokë (në pronësi dhe e marrë me qira nga të tjerët), me mesatare prej 3.9 ha tokë për ekonomi bujqësore2. Sipërfaqja e shfrytëzuar e tokës për prodhimtari bujqësore në vitin 2014 ishte 413,635 ha, ose 80\% të gjithsej sipërfaqes së tokës të shfrytëzuar nga 129,884 Ekonomi, me një mesatare të sipërfaqes së tokës së shfrytëzuar bujqësore prej 3.2 ha. Sipërfaqja e shfrytëzuar e tokës bujqësore i referohet sipërfaqes së përgjithshme të tokës së punueshme-arat, livadhet dhe kullosat, kulturat shumëvjeçare dhe kopshtet e përdorura nga Ekonomia Bujqësore, pavarësisht nga lloji i zotërimit. Në këtë kapitull janë paraqitur të dhënat: për tokën bujqësore, sipas kategorive të shfrytëzimit të tokës së punueshme: Drithëra, Perime, Pemë, Vreshta, Bimë Industriale, Foragjere, Kopshte, Fidanishte, Kultura të tjera, Livadhe dhe kullosa" (Ekstrakt). ${ }^{2}$

Tabela 3. Sipërfaqja e shfrytëzuar e tokës bujqësore 2015

(Burimi): Anketa e Ekonomive Shtepiake Bujqësore 2015, Departamenti për Vreshtari dhe Verëtari.

\begin{tabular}{|c|c|c|}
\hline Shfrytëzimi i tokës bujqësore & Sipërfaqja (ha) & $\begin{array}{c}\text { Pjesëmarrja në } \\
\%\end{array}$ \\
\hline Drithëra & 134,886 & 32.9 \\
\hline Perime & 14,656 & 3.6 \\
\hline Pemë & 4,930 & 1.2 \\
\hline Vreshta & 3,068 & 0.7 \\
\hline Industriale & 346 & 0.1 \\
\hline Foragjere & 28,472 & 6.9 \\
\hline Kopsht & 587 & 0.1 \\
\hline Fidanishte & 178 & 0.0 \\
\hline Kultura të tjera & 34 & 0.0 \\
\hline Livadhe dhe kullosa (përfshirë tokën e përbashkët) & 216,481 & 52.7 \\
\hline Tokë djerrinë & 6,787 & 1.7 \\
\hline Gjithsej sipërfaqja e shfrytëzuar e tokës bujqësore & 410,427 & 100 \\
\hline
\end{tabular}


Sipërfaqja e shfrytëzuar e tokës bujqësore në vitin 2015 ishte 410,427 ha. Pjesa më e madhe i përket: livadheve dhe kullosave (përfshirë tokën e përbashkët) 216,481 ha ose (52.7\%). Në tokën e punueshme - ara që përfshin afro $45.6 \%$, pjesa më e madhe është me drithëra kokërr. Drithërat kokërr janë mbjellë në 72,8\% (134,886,34 ha) të sipërfaqes së tokës së punueshme. apo $32.9 \%$ nga gjithsej sipërfaqja e shfrytëzuar e tokës bujqësore.

Grupi i dytë i kulturave në tokën e punueshme - ara, pas drithrave janë kulturat foragjere në sipërfaqe prej $28,472.44$ ha $(15,4 \%)$ ose pjesëmarrje prej $6.9 \%$, në gjithsej sipërfaqen e shfrytëzuar të tokës bujqësore. Perimet në vitin 2015 janë kultivuar në një sipërfaqe prej 14,656 ha (3.6\%), pemët zënë 1.2\% të totalit të tokës së punueshme me gjithsej 4,930 ha, ndërsa sipërfaqja e kultivuar me vreshta ishte 3,068 ha $(0.7 \%)$. Sa i përket tokave djerrinë kjo kategori e tokës rezulton se kishte 6,787 ha, që i bie $1.7 \%$ e sipërfaqës së shfrytëzuar të tokës bujqësore" (Ekstrakt). ${ }^{2}$

\subsection{1 Çmimet e inputeve bujqësore}

"Indeksi vjetor i çmimeve të inputeve bujqësore 2010 - 2015 përfshin të dhëna për indekset e çmimeve në Kosovë për periudhën Janar - Dhjetor 2010/2015. Çmimet e prodhimeve të inputeve bujqësore në këtë publikim janë mbledhur në barnatore bujqësore, barnatore veterinere, nga kompanitë, tregjet, dhe vendet tjera ku çmimet e inputeve bujqësore janë në dispozicion.

Produktet që përbëjnë bazën e indeksit të çmimeve të inputeve marrin pjesë në njërën nga dy grupet kryesore: Mallrat dhe shërbimet aktualisht të konsumuara në bujqësi (konsumi i ndërmjetëm) si dhe Mallrat dhe shërbimet që kontribuojnë në investimet bujqësore (formimi i kapitalit).

Çmimet e produkteve të mbrojtjes së bimëve, të cilat në katër vitet e fundit janë rritur vazhdimisht, në vitin 2015 kanë shënuar rënie mjaft të lartë prej 29\%. Rënie të dukshme prej $12 \%$ po ashtu vërehen tek kategoria e Energjisë dhe Ushqimi i kafshëve. Në anën tjetër, rritje të theksuar ka shënuar kategoria e Farërave prej $38 \%$ dhe një rritje të lehtë kategoria e Mallrave dhe Shërbimeve që kontribuojnë në Investimet Bujqësore me 4\%. Indeksi vjetor i inputeve në vitin $2015 \mathrm{ka}$ rënie për $2 \%$ për Input 1 krahasuar me periudhën e njëjtë të viti 2014. Indeksi për Input 2 është rritur për 5\% mes viteve 2015 dhe 2014. Indeksi i inputit të përgjithshëm (Input $1+$ Input 2) gjithashtu është rritur krahasuar me periudhën e njejtë të vitit 2014 për $0.7 \%$.

Brenda kategorisë së mallrave dhe shërbimeve aktualisht të konsumuara në bujqësi (Input 1), indekset e çmimeve janë llogaritur për grupet vijuese: farërat dhe materiali mbëltues, energjia, plehrat dhe përmirësuesit e tokës, produktet për mbrojtjen e bimëve, shpenzimet veterinere, ushqimi i kafshëve, mirëmbajtja e materialeve, mirëmbajtja e ndërtesave, si dhe mallrat dhe shërbimet e tjera.

Çmimet e mallrave dhe shërbimeve që lidhen me investimet bujqësore (Input 2) janë llogaritur duke përdorur çmimet e materialeve (makinerive dhe pajisjeve tjera), ndërtesat dhe të tjera, ndërtesat jo-rezidente të fermës, punët tjera përveç përmirësimit të tokës" (Ekstrakt). ${ }^{2}$ 
Tabela 4. Indeksi vjetor i çmimeve të inputeve bujqësore $2010-2015(2010=100)$ (Burimi): ASK (Indeksi i çmimeve të inputeve dhe çmimet në bujqësi), përpunuar nga DAESB - MBPZHR

\begin{tabular}{|c|c|c|c|c|c|c|c|}
\hline PËRSHKRIMI & 2010 & 2011 & 2012 & 2013 & 2014 & 2015 & $\begin{array}{c}\text { Ndryshimi } \\
2015 / 2014 \\
\text { në \% }\end{array}$ \\
\hline $\begin{array}{l}\text { MALLRAT DHE SHËRBIMET } \\
\text { E KONSUMUARA }\end{array}$ & 100.0 & 112.9 & 119.7 & 122.1 & 120.5 & 118.3 & -1.8 \\
\hline FARËRAT DHE MATERIALI MBËLTUES & 100.0 & 112.7 & 109.4 & 107.1 & 115.3 & 158.6 & 37.6 \\
\hline ENERGJI; LUBRIFIKANT & 100.0 & 114.7 & 123.4 & 118.9 & 115.7 & 102.2 & -11.7 \\
\hline -ENERGJIA ELEKTRIKE & 100.0 & 101.0 & 114.5 & 124.5 & 133.1 & 139.0 & 4.4 \\
\hline -LËNDË DJEGËSE & 100.0 & 117.1 & 125.5 & 119.1 & 114.2 & 97.8 & -14.4 \\
\hline -LUBRIFIKANT & 100.0 & 117.1 & 125.5 & 119.1 & 114.2 & 97.8 & -14.4 \\
\hline PLEHRAT DHE PËRMIRËSUESIT E TOKËS & 100.0 & 126.0 & 142.4 & 146.1 & 139.2 & 130.6 & -6.2 \\
\hline -PLEHRAT E THJESHTË & 100.0 & 130.7 & 152.2 & 155.7 & 148.1 & 135.9 & -8.2 \\
\hline -PLEHRAT E PËRBËRA & 100.0 & 130.7 & 152.2 & 155.7 & 148.1 & 135.9 & -8.2 \\
\hline $\begin{array}{l}\text { PRODUKTET PËR MBROJTJEN E BIMËVE } \\
\text { DHE PESTICIDET }\end{array}$ & 100.0 & 98.5 & 99.6 & 129.7 & 159.4 & 113.6 & -28.7 \\
\hline SHPENZIMET VETERINARE & 100.0 & 107.0 & 106.8 & 109.3 & 104.6 & 102.6 & -1.9 \\
\hline LËNDË PËR USHQIM KAFSHËSH & 100.0 & 122.3 & 137.5 & 143.4 & 130.8 & 114.4 & -12.5 \\
\hline -LËNDË TË THJESHTA USHQIMI & 100.0 & 123.7 & 140.5 & 146.0 & 131.4 & 117.2 & -10.8 \\
\hline -LËNDË TË PËRBËRA USHQIMI & 100.0 & 137.0 & 144.4 & 144.2 & 135.5 & 117.0 & -13.7 \\
\hline MIRËMBAJTJA E MATERIALEVE & 100.0 & 100.0 & 100.4 & 100.7 & 100.4 & 99.1 & -1.3 \\
\hline MIRËMBAJTJA E NDËRTESAVE & 100.0 & 100.7 & 101.6 & 100.3 & 100.4 & 99.7 & -0.7 \\
\hline MALLRAT DHE SHËRBIMET TJERA & 100.0 & 101.1 & 103.7 & 107.1 & 108.6 & 112.6 & 3.6 \\
\hline $\begin{array}{l}\text { MALLRAT DHE SHËRBIMET } \\
\text { QË KONTRIBUOJNË NË } \\
\text { INVESTIMET BUJQËSORE }\end{array}$ & 100.0 & 101.3 & 101.3 & 104.1 & 107.1 & 118.5 & 10.6 \\
\hline TRAKTOR & 100.0 & 101.3 & 101.3 & 104.1 & 107.1 & 118.5 & 10.6 \\
\hline TJERA & 100.0 & 101.3 & 101.7 & 102.0 & 103.8 & 103.1 & -0.7 \\
\hline
\end{tabular}

\subsubsection{Struktura e fermave}

Sipërfaqja e shfrytëzuar e "tokës bujqësore në Kosovë në vitin 2015 ishte 410,427 ha, nga e cila 185,385 ha $(45 \%)$ i takon tokës së punueshme apo arave. Anketa e ekonomive Bujqësore e vitit 2015 ka një strukturë tjetër dhe fermat nuk janë të ndara sipas madhësisë dhe numrit të ekonomive bujqësore.

Meqenëse madhësia e fermave është informatë shumë e rëndësishme, dhe struktura nuk mund të ndyshoj për një kohë shumë të shpejtë edhe për këtë publikim është shfrytëzuar ndarja e fermave të klasifikuara në bazë të rezultateve të Regjistrimit të Bujqësise 2014. Rezultatet nga R.B kanë treguar se ekzistojnë 113,231 Ekonomi Bujqësore që merren me prodhimin e kulturave bujqësore dhe mesatarisht posedojnë 1.6 ha të tokës së punueshme. 
Tabela 5. Struktura e fermave sipas madhësisë, Nr. i Ekonomive Bujqësore në vitin 2014 (Burimi): ASK Regjistrimi i Bujqësisë 2014

\begin{tabular}{l|c|c|c|c}
\multicolumn{1}{l}{ Madhësia e fermës } & Sipërfaqja & Pjesëmarrje & Nr. Ekonomive & Pjesëmarrja \\
\hline 0 dhe më pak se 0.5 & (ha) & në(\%) & Bujqësore & në(\%) \\
\hline 0.5 deri më pak se 1 & 16,742 & 5.1 & 39,939 & 35.2 \\
\hline 1 deri më pak se 2 & 31,905 & 9.3 & 24,562 & 21.6 \\
\hline 2 deri më pak se 5 & 55,257 & 17.7 & 23,827 & 21.0 \\
\hline 5 deri më pak se 10 & 29,518 & 16.4 & 18,726 & 16.5 \\
\hline 10 deri më pak se 20 & 15,755 & 8.7 & 4,493 & 3.9 \\
\hline 20 deri më pak se 30 & 5,303 & 2.9 & 1,203 & 1.0 \\
\hline 30 e më shumë & 16,798 & 9.3 & 228 & 0.2 \\
\hline Gjithsej & 180,381 & 100 & 113,231 & 0.2 \\
\hline
\end{tabular}

Fermat me madhësi prej 0 dhe më pak se 0.5 përbëjnë 9,142 ha, dhe kanë pjesëmarrje $5.1 \%$. Pasojnë fermat me madhësi 0.5 deri më pak se 1, që përfshijnë sipërfaqen 16,703 ha, me pjesëmarrje prej 9.3\%. Madhësia prej 1 deri më pak se 2 kanë sipërfaqen prej 31,905 ha dhe prezanton $17.7 \%$ të tokës së punueshme-arave. Sipërfaqe prej 55,257 ha, përfaqësojnë fermat me madhësi 2 deri më pak se 5 ha, që njëherit përfaqësojnë $30.6 \%$ të totalit të tokës së punueshme-arave.

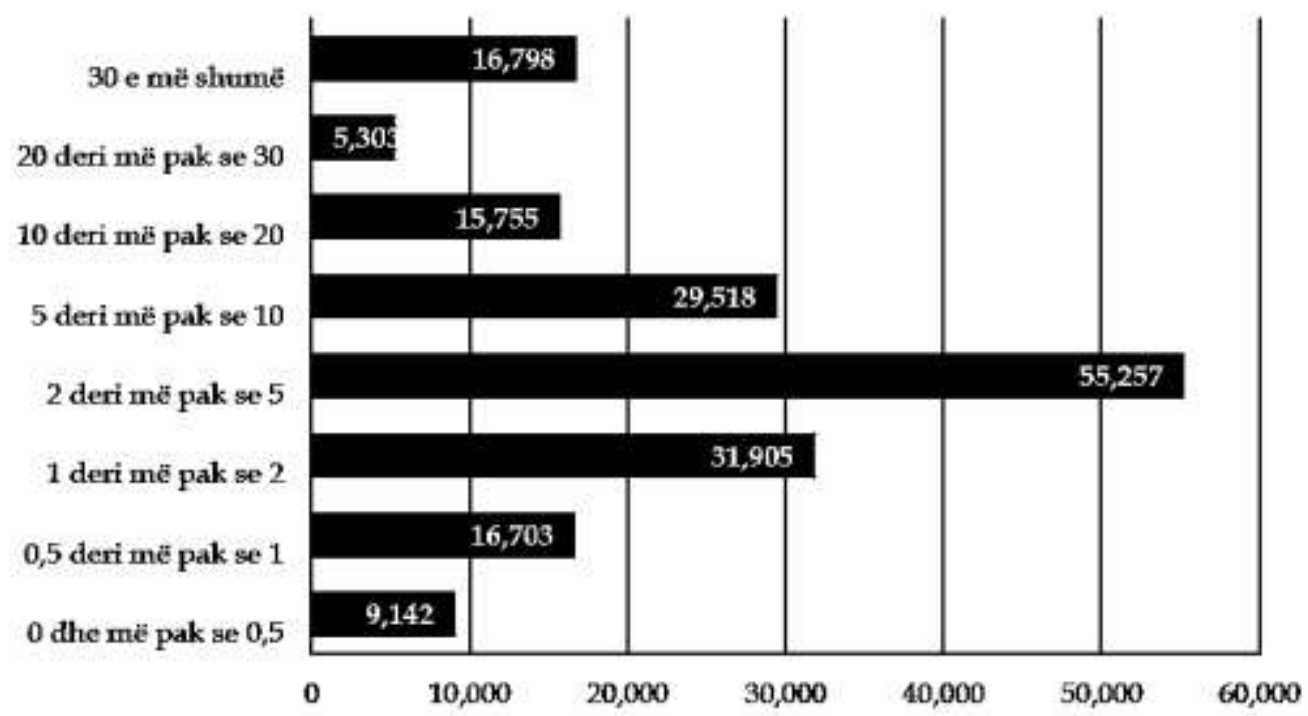

Figura 2. Struktura e fermës sipas madhësisë-sipërfaqja(ha), 2014 (Burimi): ASK Regjistrimi i Bujqësisë 2014

Bazuar në të dhënat e Regjistrimit të Bujqësisë 2014, janë 39,939 ekonomi që posedojnë ferma me madhësi 0-0.5 ha të tokës së punueshme dhe janë në përqindje më të madhe (35.2\%), ndërsa pas kategorisë së parë shumica e tokës së punueshme është kultivuar nga 24,562 ekonomi bujqësore që posedojnë ferma me madhësi prej 0.5 deri në më pak se 1 
ha të tokës së punueshme ose (21.6\%) të ekonomive. Numri i ekonomive prej 23,827 ose $21.0 \%$ e tyre posedojnë madhësi të fermave nga 1 deri në më pak se 2 ha, ndërsa kategoria tjetër e madhësisë së fermave është kultivuar nga 18,726 ose $16.5 \%$ e ekonomive bujqësore që posedojnë sipërfaqe nga 2 deri në më pak se 5 ha të tokës së punueshme që kanë pjesëmarrje prej 30.6\% të sipërfaqes së tokës të punueshme ose 55,257 ha. Madhësi të fermave nga 5 deri në më shumë se 30 ha kanë vetëm 6,177 ekonomi bujqësore, që përfaqsojnë vetëm $5.45 \%$ të ekonomive.

Sipërfaqja mesatare e tokës së punueshme - arave që kultivohet nga ekonomitë bujqësore në vitin 2014 ka qenë 1.6 ha, që do të thotë se në vendin tonë kemi vetëm 0.10 ha tokë punuese- ara për kokë banori. Madhësia mesatare e Ekonomisë Bujqësore në Kosovë, për sa i përket tokës së punueshme - arave është shumë më e vogël se sa në shumicën e shteteve të BE-së ose 8 herë më e vogël se mesatarja e këtyre shteteve, por është e ngjashme me shtetet fqinje. Nga shtetet e BE-së madhësi mesatare më të madhe të sipërfaqes së tokës së punueshme për ekonomi bujqësore konsiderohet të ketë R.Çeke, pastaj radhiten Sllovakia dhe Mbretëria e Bashkuar. Ndërsa në anën tjetër mesatare shumë të vogël kanë Malta dhe Mali i Zi" (Ekstrakt). ${ }^{2}$

\subsubsection{Agroindustria}

Ushqimi dhe pijet tradicionalisht përbëjnë pjesën më të madhe të konsumit familjar. "Industria ushqimore dhe agro bizneset tjera që punësojnë një numër të madh të punëtorëve të kualifikuar dhe të pakualifikuar, përbëhet nga një rrjet kompleks i aktiviteteve që kanë të bëjnë me furnizimin, konsumin, duke përfshirë këtu edhe shërbimet. Nënsektori agro- ushqimor në vendin tonë është mjaft i fragmentuar, nga njëra anë, kemi korporata të mëdha, që konkurojnë në tregun vendor dhe ndërkombëtar dhe, nga ana tjetër, ndërmarrje të vogla që shpesh u shërbejnë tregjeve lokale të përqendruara kryesisht në preferenca të specialiteteve lokale. Si i tillë, ky nënsektor luan rol kyç në fushën e zhvillimit rural dhe ruajtjen e aktiviteteve industriale në zonat rurale. Industria e ushqimit në Kosovë dhe agro bizneset tjera, për vitet 2011-2015 kanë gjeneruar $1,487,318,535 €$ të ardhura, me gjithsej 9,642 biznese aktive ku ishin të punësuar afro 36,748 punonjës. Ndërsa, vetëm në vitin 2015 , ka pasur të punësuar 8,790 persona dhe 2,130 biznese aktive si dhe qarkullim vjetor mbi 323 mil. $€$. Mund të thuhet se në krahasim me vitin paraprak, vërehet një përmirësim në shtimin e numrit të të punësuarve, bizneseve aktive si dhe qarkullimit vjetor" (Ekstrakt). ${ }^{2}$

Tabela 6. Industria ushqimore dhe agro bizneset për vitet 2011-2015 (Burimi): ASK - Departamenti i Statistikave Ekonomike

\begin{tabular}{l|c|c|c} 
Viti & Qarkullimi & Nr. i punësuarve & Nr. biznese aktive \\
\hline 2011 & $275,851,580$ & 6,046 & 1,742 \\
\hline 2012 & $285,389,767$ & 6,778 & 1,819 \\
\hline 2013 & $290,518,661$ & 7,130 & 1,896 \\
\hline 2014 & $312,188,431$ & 8,004 & 2,055 \\
\hline 2015 & $323,370,095$ & 8,790 & 2,130 \\
\hline Totali & $1,487,318,535$ & 36,748 & 9,642
\end{tabular}


Industria e ushqimit në Kosovë dhe agro bizneset tjera ${ }^{4}$, "profili strukturor i prodhimit të ushqimit, pijeve, prodhimi bimor dhe shtazor, gjuetia dhe shërbimet e lidhura me to përbëjnë një nga sektorët më të mëdhenj në ekonominë e Kosovës, që ka gjeneruar rreth 323 mil. $€$, dhe është një nga sektorët kyç në ekonominë e Kosovës që ofron punësim të vazhdueshëm në vendin tonë. Bazuar në statistikat e nxjerra nga regjistri i bizneseve, mund të vërehet se ka pasur dallime të shumta sa i përket qarkullimit vjetor, numrit të të punësuarve dhe bizneseve aktive varësisht nga regjioni.

Sa i përket numrit të të punësuarve nga të dhënat që janë të prezantuara në tabelën 6 , del se në vitet 2011-2015 gjithsej të punësuar në industrinë ushqimore dhe agro bizneseve tjera ishin 36,748. Numri tyre në vitin 2011 ishte 6,046, duke u rritur në 8,790 në vitin 2015. Pra, vërehet rritje e numrit të të punësuarve për 45\% nga viti 2011 në vitin 2015.

Prej numrit të përgjithshëm të të punësuarve në vitin 2015 afro 6,212 punonjës ose $71 \%$ ishin të angazhuar në industrinë përpunuese ushqimore, $13 \%$ në prodhimin bimor dhe shtazor, gjuetia dhe shërbimet e lidhura me to, dhe $12 \%$ në Prodhimin e drurit, produkteve të drurit dhe të tapës, peshkimi dhe akuakultura $1 \%$, ndërsa $3 \%$ janë të punësuar në nënsektor të tjerë” (Ekstrakt). ${ }^{2}$

\subsubsection{BPV në sektorin e bujqësisë dhe pylltarisë}

Blegtoria dhe produktet blegtorale vlerë më të lartë arriti në vitin 2013 (298 mil. €). "Vlera e prodhimeve blegtorale gjithsej për vitin 2015 ishte 278.9 mil. $€$, ku ishin të përfshira këto kategori: qumështi, vezët, mjalti dhe leshi i papërpunuar. Qumështi është produkti më i rëndësishëm blegtoral; me vlerë prej 132.6 mil. $€$ nga gjithsej 158.6 mil. $€$, të produkteve blegtorale, pastaj vijnë vezët me 25.9 mil. $€$.

Qumështi ka pasur një ulje prej 12.2\% në vitin 2015 krahasuar me 2014. Ndërsa vezët kanë shenuar rritje prej $18.1 \%$ krahasuar me vitin 2014. Sa i përket kategorive blegtorale kryesisht janë përfshirë shitja e mishit të kafsheve: gjedheve $47.8 \%$, deleve dhe dhive $17.7 \%$, derrave $11.2 \%$, mishit të shpezve $12.9 \%$ dhe kafshëve tjera $10.6 \%$. Prodhimi blegtoral është rritur për 7.7\% në vitin 2015 krahasuar me vitin 2014. Rritja mund të shpjegohet me rritjen e vlerës së blegtorisë dhe produkteve blegtorale.

Prandaj si rezultat i rritjes së prodhimit në kategori të cekura më lartë, prodhimi bimor dhe blegtoral gjithsej u rrit me 7.9\% në vitin 2015 në krahasim për vitin 2014. Rritje të vlerës së prodhimeve bimore në vitin 2015 krahas vitit 2014 kishte te: perimet dhe produktet e kopshtit $29.1 \%$, bimët foragjere për $6.5 \%$ dhe pemër $1.1 \%$, ndërsa te patatja kemi vlerën e njejtë. Të ardhurat sipërmarrëse të fermës në vitin 2015 janë për $12.2 \%$ më shumë se sa në vitin paraprak" (Ekstrakt). ${ }^{2}$

\footnotetext{
4 Prodhimi bimor dhe shtazor; gjuetia dhe shërbimet e lidhura me to; Pylltaria dhe prerja e drunjve; Peshkimi dhe Akuakultura; Përpunimi i produkteve ushqimore; Prodhimi i pijeve; Prodhimi i produkteve të duhanit; Prodhimi i lëkurës dhe produkteve prej lëkurës; Prodhimi i drurit dhe i produkteve të drurit dhe të tapës, përveç mobilieve; prodhimi i artikujve nga kashta dhe materialeve të gërshetuara-thurëse, Prodhimi i letrës dhe produkteve prej letrës, Prodhimi i produkteve minerale jometalike.
} 
Tabela 7. Llogaritë ekonomitë për bujqësi me çmime aktuale, në mil. $€$ (Burimi): ASK, Llogaritë Ekonomike për Bujqësi, përpunuar nga DAESB-MBPZHR

\begin{tabular}{|c|c|c|c|c|c|c|}
\hline & Llogaritë Ekonomike Bujqësore & 2011 & 2012 & 2013 & 2014 & 2015 \\
\hline 1 & Drithërat (përfshirë farërat) & 107 & 107.1 & 102.1 & 92.1 & 89.5 \\
\hline 2 & Bimët industriale & 0.05 & 0.14 & 0.12 & 0.26 & 0.17 \\
\hline 3 & Bimët foragjere & 56 & 67.8 & 95.2 & 67.3 & 71.7 \\
\hline 4 & Perimet dhe prodhimet e kopshtit & 119.6 & 104.1 & 154.4 & 82.9 & 107 \\
\hline 5 & Patatet & 20.2 & 12 & 19.6 & 23 & 23 \\
\hline 6 & Pemët & 23.2 & 32.9 & 51.9 & 54.6 & 55.2 \\
\hline 7 & Prodhimet e tjera bimore (farërat) & 3.7 & 3.5 & 4.2 & 4.5 & 4.1 \\
\hline 8 & Prodhimet bimore gjithsej & 329.7 & 327.6 & 427.6 & 324.7 & 350.7 \\
\hline 9 & Blegtoria & 96 & 92.3 & 117.3 & 85.9 & 120.3 \\
\hline 10 & Produktet blegtorale & 155.8 & 174.2 & 181.1 & 173 & 158.6 \\
\hline 11 & Prodhimet blegtorale gjithsej & 251.9 & 266.6 & 298.4 & 258.9 & 278.9 \\
\hline 12 & Prodhimet bimore dhe blegtorale gjithsej & 581.6 & 594.1 & 726 & 583.7 & 629.7 \\
\hline 13 & Shërbimet bujqësore & 14.7 & 14.5 & 20.4 & 20.2 & 18.5 \\
\hline 14 & Prodhimet bujqësore gjithsej & 596.2 & 608.6 & 746.3 & 603.9 & 648.2 \\
\hline 15 & Konsumi i ndërmjetëm gjithsej & 216.4 & 224.5 & 250 & 233.2 & 239.3 \\
\hline 16 & Vlera e shtuar bruto me çmime bazë & 384.3 & 390.3 & 305.8 & 377.3 & 416.8 \\
\hline 17 & Konsumi i kapitalit fiks & 81 & 84.5 & 93.7 & 90.6 & 95.5 \\
\hline 18 & Vlera e shtuar neto me çmime bazë & 303.3 & 305.8 & 403.6 & 286.8 & 321.3 \\
\hline 19 & Kompensimi i punëtorëve & 3.9 & 4.2 & 4.6 & 4.6 & 2.7 \\
\hline 20 & Subvencionet tjera në prodhim & 0.1 & 0 & 1.02 & 0.6 & 0.6 \\
\hline 21 & Të ardhurat faktor & 303.4 & 305.8 & 404.6 & 287.4 & 322 \\
\hline 22 & $\begin{array}{l}\text { Teprica operative / Të ardhurat e } \\
\text { përziera }\end{array}$ & 299.5 & 301.6 & 400.1 & 282.7 & 319.3 \\
\hline 23 & Qiratë shfrytëzimin e patundshmërive & 2.3 & 2.3 & 3.3 & 3.1 & 4.5 \\
\hline \multirow[t]{2}{*}{24} & Interesi i paguar & 0.9 & 0.8 & 0.6 & 0.4 & 1.4 \\
\hline & Të ardhurat sipërmarrëse & 296.3 & 298.4 & 396.2 & 279.2 & 313.2 \\
\hline
\end{tabular}

\subsubsection{Drithërat}

Në vitin 2015 “në Kosovë janë mbjellur 134,886 ha me drithëra, nga të cilët 97\% janë të kultivuar me grurë dhe misër. Gruri dhe misri janë dy kultura që për një kohë të gjatë zënë sipërfaqen më të madhe të tokës bujqësore të kultivuar. Krahasuar me vitin paraprak sipërfaqja e përgjithshme e kultivuar me drithëra ka shënuar ngritje për $2 \%$, ndërsa krahasuar me mesataren e tri viteve paraprake ka pasur rënie për $2 \%$. Në vitin 2015, sipërfaqja e të gjitha drithërave ka shënuar rënie përveç misrit sipërfaqja e të cilit është rritur për 18\%. Në vitin 2015 krahasuar me mesataren e tri viteve paraprake kulturat që kanë shënuar ulje në sipërfaqen e kultivuar kanë qenë gruri dhe tërshëra. Zvogëlimi në sipërfaqe është përcjellur edhe me prodhimtari totale më të ulët ku prodhimtaria e tërshërës në vitin 2015 krahasuar me vitin 2014 ka pësuar ulje prej 65\% e kjo si rezultat i uljes së sipërfaqës për $55 \%$ por edhe rendimentit për $24 \%$. Përveç tërshërës ulje të konsiderueshme në prodhimtari ka pasur edhe thekra dhe elbi... 
Ulje më të vogël ka pasur prodhimtaria e grurit, e kjo jo si rezultat se sipërfaqja e kultivuar ka qenë më e vogël po se rendimenti ka pësuar rënie për $7 \%$. Në grupin e drithërave në vitin 2015 vetëm prodhimtaria e misrit ka shënuar ngitje prej $13 \%$. Sipërfaqja e përgjithshme e mbjellë me drithëra në vitin 2015 ishte 134,886 ha nga të cilat $67 \%$ është e mbjellë me grurë. Prodhimi i përgjithshëm vendor ishte 304,443 tonë i cili mbulon $63.3 \%$ të nevojave vendore për konsum dhe pjesa tjetër mbulohet nga importi. Në Kosovë pjesa më e madhe e grurit është përdorur për konsum njerëzor si miell dhe pjesa tjetër është shitur dhe përdorur për ushqim të kafshëve. Vlera e prodhimtarisë së grurit ishte 57.8 mil. $€$ që është $12.8 \%$ më e ulët se në vitin 2014, e kjo si rezultat $\mathrm{i}$ uljes së sasisë së prodhimit por edhe asaj se çmimi ka qenë për $0.01 €$ më i ulët. Bilanci tregtar vazhdon të jetë negativ, në vitin 2015 sasia e grurit të importuar duke përfshirë edhe produktet e grurit është rritur për 17\% krahasuar me vitin 2014" (Ekstrakt). ${ }^{2}$

Tabela 8. Sipërfaqja, prodhimtaria dhe rendimenti i drithërave, 2009-2015 (Burimi): ASK, Anketa e ekonomive shtëpiake bujqësore; ASK-Vlerësime të ekspertëve. Regjistrimi i Bujqësisë.

\begin{tabular}{|c|c|c|c|c|c|c|c|}
\hline Kultura & 2009 & 2010 & 2011 & 2012 & 2013 & 2014 & 2015 \\
\hline Sipërfaqja & \multicolumn{7}{|c|}{ ha } \\
\hline Drithëra & 119,984 & 119,871 & 121,095 & 137,215 & 141,912 & 131,949 & 134,886 \\
\hline Grurë & 77,938 & 78,420 & 79,928 & 102,918 & 101,846 & 90,728 & 89,942 \\
\hline Misër & 35,854 & 35,424 & 35,209 & 31,181 & 36,122 & 35,038 & 41,492 \\
\hline Elb & 1,717 & 1,177 & 844 & 568 & 1,363 & 1,487 & 1,141 \\
\hline Thekër & 394 & 571 & 607 & 253 & 235 & 588 & 396 \\
\hline Tërshërë & 4,081 & 4,279 & 4,508 & 2,294 & 2,346 & 3,940 & 1,790 \\
\hline $\begin{array}{l}\text { Drithëra të } \\
\text { tjera kokërr }\end{array}$ & - & - & - & - & - & 168 & 125 \\
\hline Prodhimtaria & \multicolumn{7}{|c|}{$\mathrm{t}$} \\
\hline Drithëra & 411,208 & 430,524 & 435,034 & 438,792 & 540,136 & 463,581 & 443,584 \\
\hline Grurë & 271,373 & 294,540 & 300,203 & 345,027 & 391,727 & 331,296 & 304,443 \\
\hline Misër & 125,864 & 120,461 & 119,693 & 86,304 & 136,633 & 116,209 & 131,486 \\
\hline Elb & 5,363 & 3,642 & 2,608 & 1,808 & 4,415 & 4,716 & 3,061 \\
\hline Thekër & 834 & 1,371 & 1,457 & 740 & 571 & 1,521 & 809 \\
\hline Tërshërë & 7,774 & 10,510 & 11,072 & 4,913 & 6,790 & 9,840 & 3,415 \\
\hline $\begin{array}{l}\text { Drithëra të } \\
\text { tjera kokërr }\end{array}$ & - & - & - & - & - & - & 371 \\
\hline Rendimenti & \multicolumn{7}{|l|}{ t/ha } \\
\hline Grurë & 3.48 & 3.76 & 3.76 & 3.35 & 3.85 & 3.65 & 3.38 \\
\hline Misër & 3.51 & 3.40 & 3.40 & 2.77 & 3.78 & 3.32 & 3.17 \\
\hline Elb & 3.12 & 3.09 & 3.09 & 3.18 & 3.24 & 3.17 & 2.68 \\
\hline Thekër & 2.12 & 2.40 & 2.40 & 2.92 & 2.43 & 2.59 & 2.04 \\
\hline Tërshërë & 1.90 & 2.46 & 2.46 & 2.14 & 2.89 & 2.50 & 1.91 \\
\hline $\begin{array}{l}\text { Drithëra të } \\
\text { tjera kokërr }\end{array}$ & - & - & - & - & - & - & 2.96 \\
\hline
\end{tabular}




\subsubsection{Perimet}

Gjatë vitit 2015 sipërfaqja me perime në Kosovë llogaritet të jetë gjithsej 14,656 ha, e për dallim nga viti 2014, ku kjo sipërfaqe ishte 15,854 ha, në vitin 2015 sipërfaqja me perime është zvogëluar për $8 \%$. Ndër kulturat perimore të cilat dominojnë me sipërfaqe më të mëdha për vitin 2015 janë patatja, speci, fasulja dhe qepa të cilat përbëjnë $71 \%$ të gjithsej siperfaqës së kultivuar me perime. Patatja në krahasim me vitin 2014 ka shënuar zvogëlim të sipërfaqes për 9\%. Në anën tjetër, kultura e specit me 3,090 ha ka shënuar rritje në sipërfaqe për $21 \%$, domatja për $42 \%$, trangulli për $65 \%$, dhe qepa për $4 \%$. Kulturat tjera me sipërfaqe më të vogël të cilat kanë shënuar rritje krahasuar me vitin 2014 janë: pjepri, lakra, spinaqi, preshi, dhe hudhra. Tabela në vijim paraqet më së miri situatën momentale me sipërfaqet e mbuluara me perime ndër vite duke përfshirë edhe vitin 2015 si dhe ndryshimet mes tyre.

Tabela 9. Sipërfaqja me perime, 2009 - 2015

(Burimi): ASK, Anketa e ekonomive shtëpiake bujqësore; ASK-Vlerësime të ekspertëve.

Regjistrimi i Bujqësisë.

\begin{tabular}{|c|c|c|c|c|c|c|c|}
\hline Kultura & 2009 & 2010 & 2011 & 2012 & 2013 & 2014 & 2015 \\
\hline Sipërfaqja & \multicolumn{7}{|c|}{ ha } \\
\hline Perime & 15,839 & 16,356 & 16,196 & 14,557 & 16,356 & 15,854 & 14,656 \\
\hline Patate & 3,376 & 3,760 & 3,746 & 3,198 & 2,777 & 3,695 & 3,353 \\
\hline Domate & 821 & 935 & 967 & 1,271 & 950 & 558 & 791 \\
\hline Patëllxhan i zi & 5 & 6 & 5 & 2 & 8 & - & 5 \\
\hline Spec & 2,955 & 2,914 & 2,993 & 3,153 & 3,686 & 2,553 & 3,090 \\
\hline Kungull & 986 & 956 & 880 & 671 & 1,005 & 1,354 & 551 \\
\hline Kungull misiri & 74 & 94 & 94 & 106 & 96 & 232 & 229 \\
\hline Kërpudha & 1 & 1 & 2 & 2 & - & 1 & \\
\hline Trangull & 316 & 343 & 359 & 255 & 340 & 193 & 317 \\
\hline Shalqi & 954 & 1,141 & 1,240 & 847 & 827 & 781 & 781 \\
\hline Pjepër & 118 & 175 & 171 & 271 & 455 & 167 & 193 \\
\hline Lakër & 962 & 836 & 842 & 568 & 851 & 556 & 594 \\
\hline Lulelakër & 12 & 7 & 4 & 13 & 29 & - & 32 \\
\hline Spinaq & 50 & 71 & 75 & 40 & 55 & 139 & 204 \\
\hline Sallatë & 37 & 48 & 51 & 29 & 75 & - & 59 \\
\hline Panxhar & 5 & 40 & 43 & 2 & 5 & 58 & $19^{*}$ \\
\hline Rrepkë & 3 & 3 & 3 & 1 & 2 & - & 2 \\
\hline Majdanoz & 8 & 11 & 11 & 9 & 20 & - & 9 \\
\hline Presh (purri) & 62 & 113 & 121 & 93 & 143 & 44 & 78 \\
\hline Qepë & 798 & 1,043 & 1,074 & 881 & 1,060 & 1,041 & 1,079 \\
\hline Hudhër & 97 & 150 & 152 & 141 & 193 & 85 & 114 \\
\hline Fasule & 4,112 & 3,609 & 3,260 & 2,954 & 3,648 & 3,959 & 2,945 \\
\hline Bizele & 33 & 32 & 34 & 7 & 52 & 241 & 134 \\
\hline Bishtajoret tjera & 11 & 15 & 13 & 16 & 30 & 59 & 19 \\
\hline Karrota & 43 & 53 & 56 & 27 & 49 & 76 & 57 \\
\hline Perime tjera & - & - & - & - & - & 64 & - \\
\hline
\end{tabular}




\subsubsection{Pemët dhe vreshtat}

Sipërfaqja e përgjithshme me pemë në vitin 2015 ka shënuar rritje për 16\% krahasuar me vitin 2014. Në vitin 2015, sipërfaqja e mbjellur me pemë ishte 7,998 ha, e dominuar nga kulturat si molla me sipërfaqe të mbjellur 1,972 ha, kumbulla me sipërfaqe prej 1,518 ha, pasuar edhe nga kulturat tjera si dredhëza, mjedra, etj.

Ndër kulturat të cilat kanë shënuar rritje në sipërfaqe të kultivuar krahasuar me vitin 2014 vlenë të ceken: dardha e cila këtë vit është rritur në sipërfaqe për $75 \%$, vishnja me $18 \%$, manaferra me $29 \%$, si dhe mjedra, ftoni dhe arra janë rritur në sipërfaqe me mbi $100 \%$. Tek kulturat të cilat vërehet zvogëlim i sipërfaqeve janë: kajsia, pjeshka, qershia, lajthija, etj. Tabela e sipërfaqeve me pemë në vijim shpreh më në detaje ndryshimin e kulturave nëpër vite (Ekstrakt). ${ }^{2}$

Tabela 10. Sipërfaqja me pemë, 2009 - 2015

(Burimi): ASK, Anketa e ekonomive shtëpiake bujqësore; ASK-Vlerësime të ekspertëve. Regjistrimi i Bujqësisë.

\begin{tabular}{|c|c|c|c|c|c|c|c|}
\hline Kultura & 2009 & 2010 & 2011 & 2012 & 2013 & 2014 & 2015 \\
\hline Sipërfaqja & \multicolumn{7}{|c|}{ ha } \\
\hline Frutat & 6,027 & 6,578 & 6,733 & 7,082 & 8,342 & 6,921 & 7,998 \\
\hline Molla & 1,355 & 1,661 & 1,790 & 1,725 & 2,024 & 1,973 & 1,972 \\
\hline Dardha & 261 & 352 & 354 & 326 & 561 & 210 & 367 \\
\hline Ftoni & 28 & 39 & 38 & 52 & 111 & 26 & 58 \\
\hline Mushmolla & 12 & 22 & 22 & 16 & 35 & 21 & - \\
\hline Kumbulla & 1,060 & 1,063 & 1,063 & 1,404 & 1,843 & 699 & 1,518 \\
\hline Kajsia & 10 & 16 & 13 & 22 & 47 & 23 & 12 \\
\hline Pjeshka & 17 & 41 & 42 & 39 & 84 & 28 & 12 \\
\hline Qershia & 35 & 50 & 50 & 50 & 88 & 51 & 27 \\
\hline Vishnja & 69 & 58 & 58 & 107 & 106 & 125 & 147 \\
\hline Arra & 74 & 63 & 75 & 57 & 91 & 48 & 177 \\
\hline Lajthia & 12 & 13 & 15 & 2 & 22 & 88 & 65 \\
\hline Dredhëza & 26 & 49 & 45 & 52 & 148 & 201 & 203 \\
\hline Mjedëra & 1 & 1 & 0 & 0 & 23 & 141 & 324 \\
\hline Manaferra & 10 & 10 & 10 & 10 & & 15 & 19 \\
\hline Rrush për verë & 2,420 & 2,504 & 2,510 & 2,517 & 2,408 & 2,420 & 2,321 \\
\hline Rrush tryeze & 637 & 636 & 648 & 702 & 751 & 781 & 747 \\
\hline Gështenja & - & - & - & - & - & 24 & - \\
\hline Boronica & - & - & - & - & - & 14 & 14 \\
\hline Pemë tjera & - & - & - & - & - & 32 & 14 \\
\hline
\end{tabular}




\subsubsection{Vreshtat}

Sipërfaqja e përgjithshme me vreshta në vitin 2015 ishte 3,068 ha. "Krahasuar me vitin 2014, kjo sipërfaqe ka pak dallim me vetëm $4 \%$ sipërfaqe më të vogël. Nga sipërfaqja e përgjithshme me vreshta në vitin 2015, 24\% kanë qenë të mbjellura me rrush tryeze. Prodhimi i rrushit ka shënuar rritje mjaft të madhe për $44 \%$ nga viti 2014, e kjo për shkak të kushteve më të mira klimatike gjatë vitit 2015. Shkalla e vetmjaftueshmërisë për rrush tryeze është ende e ulët dhe si rezultat gjatë vitit 2015, për t'i përmbushur nevojat vendore janë importuar rreth 2,025 tonë ndërsa janë eksportuar vetëm 28 tonë rrush tryeze. Bilanci tregtar ka vazhduar të jetë negativ edhe në vitin 2015, mirëpo krahasuar me vitin 2014, është përmirësuar për 710 mijë $€$.

Tabela 11. Bilanci i furnizimit për rrush tryeze, 2011 - 2015 (Burimi): ASK, Statistikat e Tregtisë së Jashtme; Departamenti për Vreshtari dhe Verëtari - MBPZHR; kalkulime nga DAESB - MBPZHR

\begin{tabular}{l|c|c|c|c|c|c} 
& Njësia & $\mathbf{2 0 1 1}$ & $\mathbf{2 0 1 2}$ & $\mathbf{2 0 1 3}$ & $\mathbf{2 0 1 4}$ & $\mathbf{2 0 1 5}$ \\
\hline Sipërfaqja me vreshta & ha & 3,158 & 3,220 & 3,159 & 3,201 & 3,068 \\
\hline Sipërfaqja me rrush tryeze & ha & 648 & 703 & 751 & 767 & 747 \\
\hline Pjesëmarrja & $\%$ & 21 & 22 & 24 & 24 & 24 \\
\hline Rendimenti & $\mathrm{t} / \mathrm{ha}$ & 7 & 10 & 9.5 & 7 & 9 \\
\hline Prodhimi & $\mathrm{t}$ & 4,536 & 7,026 & 7,137 & 4,869 & 6,996 \\
\hline Importi i rrushit të tryezës & $\mathrm{t}$ & 2,011 & 1,764 & 2,762 & 2,920 & 2,025 \\
\hline Furnizimi me rrush tryeze & $\mathrm{t}$ & 6,547 & 8,790 & 9,899 & 7,789 & 9,021 \\
\hline Eksporti i rrushit të tryezës & $\mathrm{t}$ & 8 & 454 & 40 & 96 & 28 \\
\hline Përdorimi vendor & $\mathrm{t}$ & 6,539 & 8,336 & 9,859 & 7,693 & 8,993 \\
\hline $\begin{array}{l}\text { Shkalla e vetë } \\
\text { mjaftueshmërisë }\end{array}$ & $\%$ & 69 & 84 & 72 & 63 & 78 \\
\hline $\begin{array}{l}\text { Përdorimet e rrushit të } \\
\text { tryezës }\end{array}$ & $\mathrm{t}$ & 6,539 & 8,336 & 9,859 & 7,693 & 8,993 \\
\hline $\begin{array}{l}\text { Çmimet e prodhuesit } \\
\text { (fermë) }\end{array}$ & $€ / \mathrm{kg}$ & 0.93 & 0.93 & 0.81 & 1.02 & 0.91 \\
\hline $\begin{array}{l}\text { Vlera e prodhimit } \\
\text { Bilanci tregtar }\end{array}$ & $\mathrm{mil.} \mathrm{EUR}$ & 4.22 & 6.53 & 5.78 & 4.97 & 6.37 \\
\hline
\end{tabular}

Sipërfaqja e kultivuar me varietete të rrushit të tryezës në Kosovë në vitin 2015 ishte 747 ha. Nga llojet e varieteteve të rrushit të tryezës, pjesa më e madhe është e kultivuar me varietetin Muskat Hamburg me sipërfaqe prej 257 ha, me varietetin Muskat Italian me 168 ha, dhe varietetin Afuz Ali me 121 ha. Varietetet tjera kultivohen në sipërfaqe më të vogël dhe përbejnë 201 ha të gjithsej sipërfaqes së kultivuar me rrush tryeze. Në Kosovë ka më shumë se 40 varietete të rrushit që kultivohen për qëllime të ndryshme. Sipërfaqja e kultivuar me varietete të kuqe është më e madhe se ajo me varietete të bardha për $98 \%$. Nga sipërfaqja prej 1,542 ha të kultivuar më rrush të kuq prinë varieteti Vranac më 437 ha të kultivuar, pasuar nga varieteti Prokupë me 376 ha, varieteti Game me 265 ha, Burgundez i Zi me 155 ha, si dhe lloje tjera që përbëjnë sipërfaqen e kultivuar me varietete të kuqe me gjithsej 309 ha "(Ekstrakt). 


\subsubsection{Kulturat foragjere dhe drithërat e gjelbërta}

Në grupin e kulturave foragjere dhe drithërave të kositura të gjelbërta, në vitin 2015 rritje të sipërfaqes kanë shënuar bari me $47 \%$, foragjeret e tjera të gjelbërta me $118 \%$ si dhe jonxha me 1\%. Rritja në sipërfaqen e barit është shoqëruar edhe me një rritje të rendimentit prej 0.23 tonë duke bërë që gjithsej prodhimtaria e barit të rritet për 59\%. Rënie në sipërfaqen e kultivuar kanë shënuar misri i gjelbërt me 7\% dhe tërfilli me $75 \%$. Situatë e ngjajshme vërehet edhe nëse krahasojmë vitin 2015 me mesataren e tri viteve paraprake përveç kategorisë foragjere tjera të gjelbërta.

Tabela 12. Sipërfaqja, prodhimtaria dhe rendimenti i kulturave foragjere dhe drithërave të kositura të gjelbëra, 2009-2015

(Burimi): ASK, Anketa e ekonomive shtëpiake bujqësore; ASK-Vlerësime të ekspertëve. Regjistrimi i Bujqësisë.

\begin{tabular}{|c|c|c|c|c|c|c|c|}
\hline Kultura & 2009 & 2010 & 2011 & 2012 & 2013 & 2014 & 2015 \\
\hline Sipërfaqja & \multicolumn{7}{|c|}{ ha } \\
\hline $\begin{array}{l}\text { Foragjere dhe drithëra të } \\
\text { kositura të gjelbërta }\end{array}$ & 91,426 & 99,043 & 98,833 & 94,444 & 110,314 & 26,554 & 97,183 \\
\hline Misër (i gjelbërt) & 1,094 & 1,062 & 1,032 & 2,511 & 4,294 & 2,414 & 2,256 \\
\hline Sanë (livadhe) & 66,875 & 74,952 & 76,386 & 72,048 & 81,924 & - & 68,711 \\
\hline Përzirje e barit & 3,860 & 2,733 & 1,645 & 3,677 & 5,036 & 6,689 & 9,809 \\
\hline Jonxhë & 13,188 & 14,678 & 14,707 & 13,330 & 15,495 & 15,011 & 15,109 \\
\hline Tërfill & 3,529 & 2,582 & 2,577 & 1,328 & 1,502 & 2,085 & 526 \\
\hline $\begin{array}{l}\text { Foragjeret e tjera } \\
\text { të gjelbërta }\end{array}$ & 2,880 & 3,035 & 2,486 & 1,550 & 2,063 & 355 & 772 \\
\hline Prodhimtaria & \multicolumn{7}{|c|}{$\mathrm{t}$} \\
\hline $\begin{array}{l}\text { Foragjere dhe drithëra të } \\
\text { kositura të gjelbërta }\end{array}$ & 257,768 & 398,556 & 396,049 & 259,522 & 393,087 & 151,095 & 317,888 \\
\hline Misër (i gjelbërt) & 18,209 & 15,944 & 15,493 & 28,006 & 82,050 & 36,434 & 31,633 \\
\hline Sanë (livadhe) & 168,607 & 208,058 & 212,037 & 166,519 & 217,155 & - & 194,768 \\
\hline Bari & 12,043 & 9,269 & 5,578 & 8,980 & 14,836 & 19,575 & 31,028 \\
\hline Jonxhë & 42,416 & 145,054 & 145,054 & 46,828 & 60,869 & 86,583 & 53,368 \\
\hline Tërfill & 9,356 & 8,009 & 7,994 & 3,908 & 5,889 & 6,924 & 1,784 \\
\hline $\begin{array}{l}\text { Foragjeret e tjera } \\
\text { të gjelbërta }\end{array}$ & 7,137 & 12,223 & 9,893 & 5,281 & 12,288 & 1,579 & 5,308 \\
\hline Rendimenti & \multicolumn{7}{|l|}{ t/ha } \\
\hline Misër (i gjelbërt) & 16.64 & 15.01 & 15.01 & 11.15 & 19.11 & 15.09 & 14.02 \\
\hline Sanë (livadhe) & 2.52 & 2.78 & 2.78 & 2.31 & 2.65 & - & 2.83 \\
\hline Bari & 3.12 & 3.39 & 3.39 & 2.44 & 2.95 & 2.93 & 3.16 \\
\hline Jonxhë & 3.22 & 9.88 & 9.86 & 3.51 & 3.93 & 5.77 & 3.53 \\
\hline Tërfill & 2.65 & 3.10 & 3.10 & 2.94 & 3.92 & 3.32 & 3.39 \\
\hline $\begin{array}{l}\text { Foragjeret e tjera } \\
\text { të gjelbërta }\end{array}$ & 2.48 & 4.03 & 3.98 & 3.41 & 5.96 & 4.45 & 6.87 \\
\hline
\end{tabular}




\subsubsection{Kulturat industriale}

Sipërfaqja e kultivuar me kultura industriale në vitin 2015 dominohet kryesisht nga bimët aromatike mjekuese (54.6\%) dhe luledielli (44.5\%), ndërsa pjesa tjetër prej $0.9 \%$ është e mbjellur me kultura të tjera industriale. Prodhimtaria totale e kulturave industriale është 757 tonë me pjesëmarrje të prodhimtarisë së lulediellit prej $90 \%$, kulturë e cila ka rendiment prej 4.4 tonë/ha. Nga 154 ha të kultivuar me luledielli, 135 janë mbështetur përmes pagesave direkte në shumë prej $150 € /$ ha dhe numri i fermerëve që kanë përfituar ka qenë 4 fermerë nga regjioni i Prishtinës dhe Pejës përkatësisht komunat: Lipjan, Drenas dhe Junik" (Ekstrakt). ${ }^{2}$

Tabela 13. Sipërfaqja, prodhimtaria dhe rendimenti i kulturave industriale, 2014-2015 (Burimi): ASK - Regjistrimi i Bujqësisë 2014; Anketa e Ekonomive Bujqësore 2015

\begin{tabular}{l|c|c|c} 
Kultura & $\mathbf{2 0 1 4}$ & & $\mathbf{2 0 1 5}$ \\
\hline Sipërfaqja & & ha & \\
\hline Kultura industriale & 595 & & 346 \\
\hline Duhani & 7 & & - \\
\hline Luledielli & 355 & & 154 \\
\hline $\begin{array}{l}\text { Bimët aromatike dhe } \\
\text { mjekuese }\end{array}$ & 209 & & 189 \\
\hline Kultura tjera industriale & 24 & & 3 \\
\hline Prodhimtaria & & t & \\
\hline Kultura industriale & & & 757 \\
\hline Luledielli & & & 678 \\
\hline $\begin{array}{l}\text { Bimët aromatike dhe } \\
\text { mjekuese }\end{array}$ & & & 71 \\
\hline Kultura tjera industriale & & & 7 \\
\hline Rendimenti & & t/ha & \\
\hline Luledielli & & & 4.40 \\
\hline $\begin{array}{l}\text { Bimët aromatike dhe } \\
\text { mjekuese }\end{array}$ & & 0.38 \\
\hline $\begin{array}{l}\text { Kultura tjera industriale } \\
\text { Kultar }\end{array}$ & & 2.48
\end{tabular}

\subsubsection{Gjedhët}

Në vitin 2015, "blegtoria gjeneroi prodhim vjetor prej 278.94 mil. $€$ e kjo duke përfshirë edhe subvencionet në produkt. Në kuadër të blegtorisë, për nga numri i krerëve por edhe të ardhurat që gjenerohen, gjedhet kanë rëndësinë më të madhe krahasuar me sektorët e tjerë blegtoral. Pjesëmarrja e gjedheve në strukturën e kafshëve është rreth $49 \%$, përkatësisht janë gjithsej 258,504 krerë. Sa i përket pjesëmarrjes së kategorive të ndryshme brenda strukturës së gjedheve dominojnë lopët qumështore më pjesëmarrje $53 \%$ dhe janë bartëse të prodhimtarisë së qumështit në Kosovë. Numri i krerëve të prezantuar në kategorinë lopë të tjera, janë ato që nuk janë lopë qumështore dhe që nuk marrin pjesë në reproduksion. Shikuar në aspektin e grupmoshave kategoria gjedhe të moshës 2 e më shumë vjet përbën $60 \%$, pasuar nga kategoria gjedhe të moshës më pak se 1 vjet me 31\%, dhe ajo e moshës 1 deri në më pak se 2 vjet me $9 \%$. 
Struktura gjinore e gjedheve është shumë e ndryshme në grupmosha të ndryshme... Gjinia femërore dominon në kategorinë gjedhe të moshës dy e më shumë vjet duke qenë se gjedhet e gjinisë mashkullore janë të destinuara kryesisht për therrje. Në kategorinë nën 1 vjet meshkujt janë pak më dominues sesa femrat ndërsa në kategorinë prej $1 \mathrm{e}$ deri në më pak se 2 vjet dominojnë femrat me $60 \%$.

Numri i përgjithshëm i gjedheve në vitin 2015 është zvogëluar për 1\% krahasuar me vitin 2014, ndërsa krahasuar me mesataren '12-'14 ulja ka qenë 15\%. Numri i lopëve qumështore është rritur për 1\% krahasuar me vitin 2014 ndërsa krahasuar me mesataren e tri viteve paraprake ka pasur zvogëlim të numrit të lopëve qumështore për 18\%" (Ekstrakt). ${ }^{2}$

Tabela 14. Fondi dhe struktura e gjedhëve, 2009-2015

(Burimi): ASK - Anketa e ekonomive shtëpiake bujqësore.

ASK-Vlerësime të ekspertëve . Regjistrimi i Bujqësisë ('14); Vlerësime DAESB ('09-'13).

\begin{tabular}{l|c|c|c|c|c|c|c} 
Numri i kafshëve & $\mathbf{2 0 0 9}$ & $\mathbf{2 0 1 0}$ & $\mathbf{2 0 1 1}$ & $\mathbf{2 0 1 2}$ & $\mathbf{2 0 1 3}$ & $\mathbf{2 0 1 4}$ & $\mathbf{2 0 1 5}$ \\
\hline Fondi i gjedheve & 343,823 & $\mathbf{3 5 6 , 4 9 6}$ & 361,688 & $\mathbf{3 2 9 , 2 1 3}$ & 321,113 & 261,689 & 258,504 \\
\hline Viça meshkuj nën 1 vjet & 67,854 & $\mathbf{7 4 , 4 3 8}$ & $\mathbf{7 6 , 2 8 3}$ & $\mathbf{6 6 , 5 7 5}$ & 65,298 & 47,357 & 45,235 \\
\hline Viça femra nën 1 vjet & 51,661 & 56,673 & 58,078 & 50,687 & 49,715 & 36,055 & 36,108 \\
\hline Viça meshkuj 1-2 vjet & 14,700 & 12,870 & 13,375 & 12,333 & 10,756 & 14,351 & 9,007 \\
\hline Viça femra 1-2 vjet & 11,190 & 9,798 & 10,182 & 9,389 & 8,188 & 10,925 & 13,737 \\
\hline Meshkuj mbi 2 vjet & 3,340 & 3,247 & 3,223 & 2,538 & 2,831 & 2,872 & 2,639 \\
\hline Mëshqerra & 4,862 & 4,486 & 4,392 & 4,351 & 5,768 & 13,920 & 12,138 \\
\hline Lopë qumështore & 190,216 & 194,984 & 196,155 & 183,340 & 178,557 & 134,393 & 135,801 \\
\hline Lopë të tjera & - & - & - & - & - & 1,816 & 3,839 \\
\hline Buallica & 255 & 231 & 190 & 159 & 272 & 670 &
\end{tabular}

Numri i përgjithshëm i gjedheve në vitin 2015 ishte 258,504 e krahasuar me vitin 2014 rënia ishte $1 \%$. Sa i përket therjes, 115,195 krerë janë therur në vitin 2015 që dmth më pak se në vitin 2014 për $10 \%$.

Vlera e prodhimit të përgjithshëm ishte 41.4 mil. $€$, ndërsa vlera e importit 33.5 mil. $€$. Me këtë sasi të prodhimit shkalla e vetë-mjaftueshmërisë është $60.4 \%$ dhe konsumi për kokë banori është $18.4 \mathrm{~kg}$.

Lopët qumështore përbëjnë 52.5\% të numrit të përgjithshëm të gjedheve dhe në vitin 2015 numri i lopëve qumështore është 1\% më i lartë se në vitin 2014. Nga furnizimi i përgjithshëm $80.9 \%$ ishte prodhim vendor dhe pjesa tjetër është mbuluar nga importet.

Bilanci tregtar mbetet negativ me 25 mil. $€$. Konsumi për kokë banori llogaritet të jetë $197 \mathrm{~kg}$ në vit që do të thotë se një person konsumon rreth $0.6 \mathrm{~kg}$ në ditë duke përfshirë të gjitha produktet e qumështit. 
Tabela 15. Bilanci i furnizimit, qumështi dhe produktet e qumështit të lopës, 2011-2015 (Burimi): ASK - Anketa e ekonomive shtëpiake bujqësore ('09,'12'13,'15) ); ASK-Vlerësime të ekspertëve; Regjistrimi i Bujqësisë ('14); ASK, Statistikat e Tregtisë së Jashtme; kalkulime nga DAESB - MBPZHR

\begin{tabular}{l|c|c|c|c|c|c} 
& Njësia & $\mathbf{2 0 1 1}$ & $\mathbf{2 0 1 2}$ & $\mathbf{2 0 1 3}$ & $\mathbf{2 0 1 4}$ & $\mathbf{2 0 1 5}$ \\
\hline Lopë qumështore & krerë & 196,155 & 183,340 & 178,557 & 134,393 & 135,801 \\
\hline Prodhimi i qumështit & $\mathrm{t}$ & 393,389 & 368,605 & 369,702 & 278,933 & 282,534 \\
\hline Importi & $\mathrm{t}$ (p.e.) & 75,960 & 72,371 & 66,582 & 67,863 & 67,491 \\
\hline Furnizimi & $\mathrm{t}$ (p.e.) & 469,349 & 440,976 & 436,284 & 346,796 & 350,025 \\
\hline Eksporti & $\mathrm{t}$ (p.e.) & 360 & 110 & 422 & 378 & 800 \\
\hline Përdorimi vendor & $\mathrm{t}$ (p.e.) & 468,989 & 440,867 & 435,862 & 346,418 & 349,224 \\
\hline Shkalla mjaftueshmërisë & $\%$ & 83.9 & 83.6 & 84.8 & 80.5 & 80.9 \\
\hline Humbjet & $\mathrm{t}($ p.e.) & 7,868 & 7,372 & 7,394 & 5,579 & 5,651 \\
\hline Konsumi -ushqim viçave & $\mathrm{t}$ (p.e.) & 57,828 & 54,185 & 54,346 & 41,003 & 41,532 \\
\hline Procesimi & $\mathrm{t}$ (p.e.) & 35,684 & 33,578 & 33,046 & 26,690 & 26,868 \\
\hline Konsumi njerëzor & $\mathrm{t}($ p.e.) & 367,609 & 345,731 & 341,075 & 273,146 & 275,173 \\
\hline $\begin{array}{l}\text { Çmimet e prodhuesit (në } \\
\text { fermë) }\end{array}$ & €/kg & 0.31 & 0.32 & 0.33 & 0.33 & 0.30 \\
\hline Vlera e prodhimit & mil EUR & 101.6 & 98.3 & 101.6 & 76.7 & 70.6 \\
\hline Bilanci tregtar & mil EUR & -24.5 & -25.4 & -23.4 & -25.5 & -25.5
\end{tabular}

\subsubsection{Shpeztaria}

Sektori i shpeztarisë në Kosovë është kryesisht i orientuar tek prodhimtaria e vezëve, ndërsa prodhimtaria e mishit të pulës është më pak e zhvilluar. Në vitin 2015 numri i përgjithshëm i shpezëve ishte 2,576 mijë shpezë dhe $97 \%$ e tyre janë pula ndërsa pjesa tjetër janë shpezë të tjera duke përfshirë bibat, rosat, patat etj. Nga gjithsej numri i pulave $75 \%$ janë pula për vezë dhe numri i tyre në vitin 2015 është rritur për $10 \%$ krahasuar me vitin paraprak. Në përgjithësi numri i shpezëve në vitin 2015 është zvogëluar për 4\%. Krahasuar me mesataren e tri viteve të fundit numri i shpezëve në vitin 2015 është rritur për $7 \%$, ndërsa vetëm kategoria e pulave përjashtuar bibat, rosat dhe patat, ka shënuar rritje prej $8 \%$. Pjesëmarrja e brojlerëve në gjithsej numrin e pulave është 12\%, e kjo është një tregues që prodhimtaria a mishit të pulës vazhdimisht është në rritje" (Ekstrakt). ${ }^{2}$

Tabela 16. : Numri i shpezëve dhe vezëve 2009-2015, në 1000 krerë (Burimi): ASK - Anketa e ekonomive shtëpiake bujqësore ('09,'12'13,'15) ); ASK-Vlerësime të ekspertëve; Regjistrimi i Bujqësisë Vlerësime: DPBT ('09-'11), SHPUK ('12-'13), DAESB ('14-'15)

\begin{tabular}{l|c|c|c|c|c|c|c} 
Numri i shpezëve (1000) & $\mathbf{2 0 0 9}$ & $\mathbf{2 0 1 0}$ & $\mathbf{2 0 1 1}$ & $\mathbf{2 0 1 2}$ & $\mathbf{2 0 1 3}$ & $\mathbf{2 0 1 4}$ & $\mathbf{2 0 1 5}$ \\
\hline Shpezë & 2,390 & 2,347 & 2,347 & 2,318 & 2,244 & 2,692 & 2,576 \\
\hline Pula & 2,220 & 2,220 & 2,220 & 2,250 & 2,108 & 2,584 & 2,492 \\
\hline Brojler & & & & & & 194 & 304 \\
\hline Pula për vezë & & & & & & 1,704 & 1,874 \\
\hline Zogj, pula dhe gjela të tjerë & & & & & & 687 & 314 \\
\hline Biba & & & & & & 45 & 63 \\
\hline Rosa dhe pata & & & & & & 18 & 22 \\
\hline Shpezë të tjera & 127 & 127 & 127 & 68 & 136 & 44 & - \\
\hline Vezë* & 238,854 & 231,608 & 224,582 & 218,282 & 176,078 & 357,138 & 361,197
\end{tabular}


KJO FAQE ËSHTË LËNË QËLLIMISHT E ZBRAZËT! 


\section{FERMAT VERTIKALE}

\subsection{KONCEPTET DHE PARIMET}

Doka bujqësore përherë gjatë historisë ka dominuar si vlerë e shtrenjtë dhe e çmuar. Gjersa popullsia në mbarë botën vazhdon të rritet, kërkesa për më shumë ushqim dhe më shumë tokë për të kultivuar ushqimin është gjithnjë në rritje. Aktualisht, vërehet tendenca e një zgjidhje për nevojën tonë për më shumë hapësirë të cilën afër e gjejmë në depot e braktisura, ndërtesa të reja të ndërtuara në dëm të mjedisi, dhe sipërfaqe të braktisura të qyteteve tona. Në aspektin global vërehen veprime konkrete në kultivimin e bimësisë në 'vertikale' e ashtuquajtur në fermat vertikale, duke përfshirë: kultivimin e të mbjellave në ambientet e brendshme me kontroll të dritës precize, tretjeve ushqyese, lagështisë dhe temperaturës së saktë dhe të kërkuar. Në fermat vertikale, bimët të cilat kultivohen mund të arrijnë edhe në disa etazha në vertikale.

Nga historiografia mësojmë se edhe pse të vogla, këto kopshte banesore në ertikale janë zhvilluar me dekada më heret, fermat vertikale në nivel të mirëfilltë ekonomik kanë operuar seriozisht në Shtetet e Bashkuara viteve të fundit. Respektivisht, që nga viti 2010, SHBA-ja kishte një sfond modest të fermave vertikale për operim serioz tregtar, mirëpo, interesi për këtë teknologji të re bujqësore po rritet me shpejtësi të madhe.

Nga aspekti i qëndrueshmërisë së mjedisit, në realicion me ndërtimin e strukturave të mëdha për fermat vertikale, mund të konkludojmë se përparësitë janë të shumta, sikurse:

- Rehabilitojnë ekosistemet e dëmtuara;

- Në funksionim kursejnë: $70 \%$ më pak përdorim të ujit;

- Nuk kërkojnë burime energjetike me prejardhje fosile;

- Kursejnë tokën bujqësore;

- Mund të prodhojnë bio karburante;

- Për lokacion mund të përdorin sipërfaqe të braktisura të qytetit;

- E fusin në përdorim ujin atmosferik të pastruar;

- Prodhojnë produkte ushqimore të fresketa ;

- Krijojnë vende të reja pune;

- Fusin në përdorim arkitekturën e qendrueshme bashkëkohore

- Janë të pavarura nga përdorimi i deposolit

- Përkrahin kultivime mikse të kulturave bujqësore

- Vazhdimisht produkte të freskëta pavarsisht motit dhe stines

- Ofrojnë çmime të arsyeshme dhe konkurente 


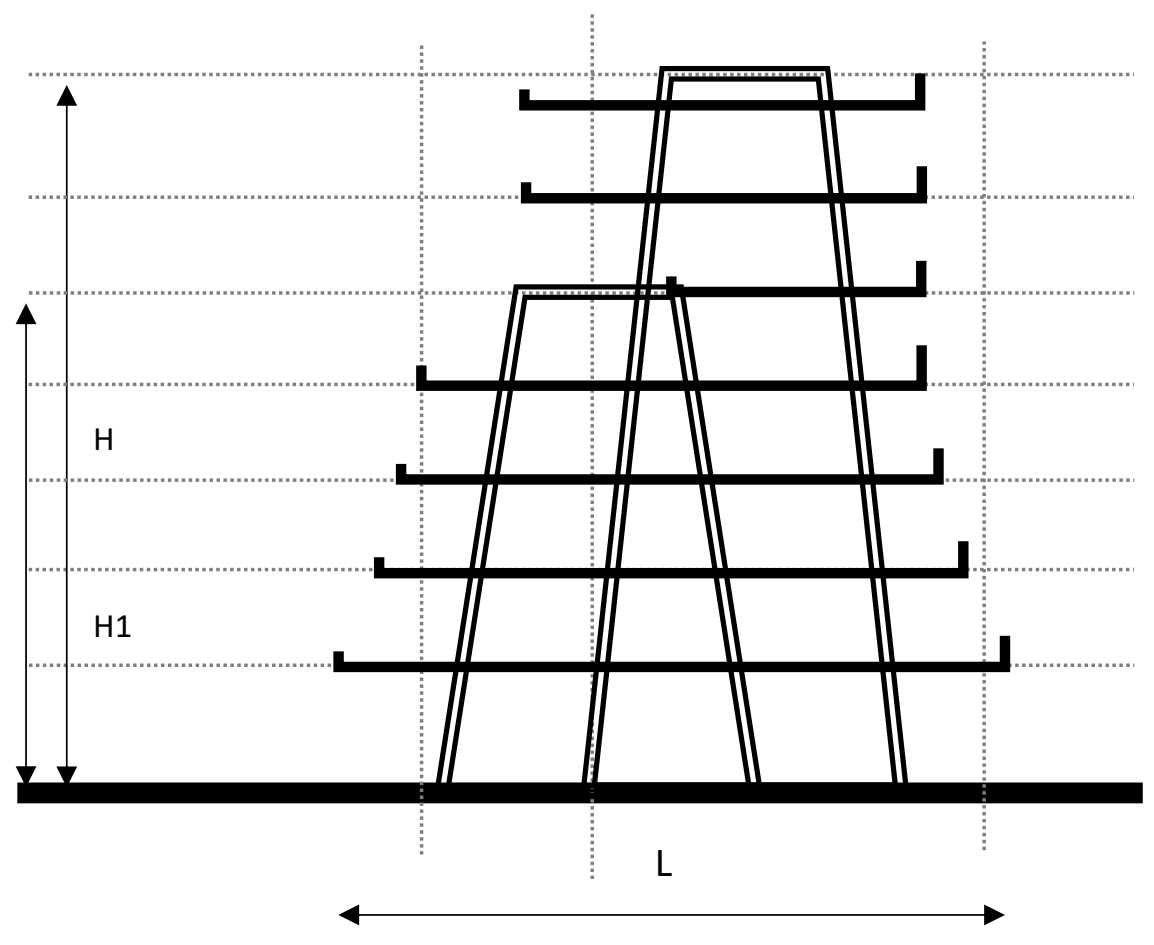

Figura 3. Fermat vertikale, racionalizimi i tokes bujqësore (Burimi): Bujar Bajçinovci, 2017.

Në përgjithësi sipas konceptit urb-arkitektonik, fermat në lartësi mund të ndahen në këto tre grupe:

1. Fermat Urbane;

2. Fermat në lartësi;

3. Fermat vertikale.

Në përgjithësi sipas metodes së kultivimit të bimësisë, fermat vertikale mund të ndahen në këto tre grupe:

1. Fermat me sistem Aeroponics;

2. Fermat me sistem Hydroponics;

3. Fermat me sistem Aquaponics.

Në përgjithësi sipas konceptit të formësimit arkitektonik, fermat vertikale mund të ndahen në këto dygrupe:

1. Fermat vertikale të realizuara në struktura të zakonshme;

2. Fermat vertikale të realizuara në mega struktura funksionale;

3. Fermat vertikale të realizuara me funksione të hibridizuara 
Në relacion nga lloji i përdorur konstruktiv, fermat vertikale mund të ndahen në:

1. Fermat vertikale të realizuara nga konstruksioni ram

2. Fermat vertikale të realizuara nga konstruksioni i kapriatave të drejta lineare

3. Fermat vertikale të realizuara nga konstruksioni i kapriatave hapësinore

4. Fermat vertikale të realizuara nga a konstruksionet hapësinore

5. Fermat vertikale të realizuara nga harqet dhe qemerret

6. Fermat vertikale të realizuara nga konstruksionet pneumatike

7. Fermat vertikale të realizuara nga konstruksionet e varura

Në relacion nga lloji i materialit të përdorur për konstruksionin konstruktiv, fermat vertikale mund të ndahen në:

1. Fermat vertikale të realizuara nga konstruksioni prej qeliku

2. Fermat vertikale të realizuara nga konstruksioni prej beton armea

3. Fermat vertikale të realizuara nga konstruksioni prej drurit të lameluar

\subsection{SFIDAT URBANE - ARKITEKTONIKE}

Konsumi i energjisë vazhdimisht në rritje, dëshmitarë të ndryshimeve klimatike globale, ndotja e mjedisit dhe implikimet për fenomenet e lartpërmendura janë në rritje! Andaj, ridefinimi i procesit projektues arkitektonik duhet të ndodhë si përgjigje bashkëkohore e shekullit të XXII, shumë aspekte janë të lidhura me procesin e integruar të projektimit, duke veçuar: qasjet transdisiplinare, holistike, kursimet dhe efiçienca e energjisë, performanca e përgjithshme e ndërtesave. Një masë e bollshme e literaturës botërore procedon hulumtimet e kësaj lëmie: sipas hulumtimit të CSU ${ }^{5}$ dhe PER $^{6}$, shpjegohet se një dizajn i integruar optimizon punën e ndërtimit dhe rritë efikasitetin e burimeve ndërtuese, marrëdhëniet e ndërsjella në mes të sistemeve të ndërtesës, eksploatimin dhe "ciklin e jetës" së ndërtesës.

Procesi i integruar i projektimit kërkon qëllim të përbashkët funksional, hartimin e rrjedhshëm dhe të vazhdueshëm të informacionit ndërmjet të gjithë palëve të involvuara në projekt. Rezultati do të jetë një "ndërtesë e tërësishme", projekt, në të cilin të gjithë sistemet e ndërtimit janë të harmonizuara me qëllim sa më të lartë të ndërveprimit, si sistem i gjërë dhe total.

Një qasje e integruar e projektimit arkitektonik është vendimtare për arritjen e projektimit të qëndrueshëm, si dhe arritjes së performancës optimale të ndërtesës. Prandaj, kërkesa për themelimin e ekipit transdisiplinar në fazat e hershme të programimit, me argumente dhe objektiva të caktuara dhe me prioritete, klasifikon dhe sinkronizon koordinim të vazhdueshëm e të gjithë anëtarëve të ekipit të projektimit.

5 California State University. http://www.calstate.edu/.

6 Program for Environmental Responsibility. http://137.145.170.165/cpdc/sustainability/envr-res.shtml 
Për më tepër, programi PER shfaq rezultate, që integrimi i ekipeve të projektimit mund të zbulojë më mirë elementët e një " konflikt të mundshëm ", për të përfituar një sinergji midis participantëve dhe ekipeve të projektimit, të cilët pastaj mund të ristrukturojnë vendimmarrjen si dhe aktivitete në drejtim të fuzionimit të ndryshimeve pasuese në fazën e projektimit. Sigurimi që në fazat e hershme të analizave së detyrës projektuese, mundëson që ekipet do të jenë në gjendje për ta konsoliduar bazën e vendimeve gjatë projektimit, duke llogaritur punën dhe ciklin e jetës së materialeve në përmirësimin e efikasitetit të energjisë, i cili redukton koston e investimeve.

Në nivelin e strategjisë së CSU, propozohet se është e nevojshme që të përfshihen të paktën disiplinat e mëposhtme dhe pjesëmarrësit në komisione për planifikimin e strategjisë, sikurse: stafi planifikues menaxherial, arkitektë, arkitektë peizazhi, inxhinierë, inxhinierë instalimesh, specialistë në qëndrueshmëri, teknolog, specialistë të shëndetit publik, personel operacional dhe subspecializantët e lëmive të tjera të nevojshme.

Në procesin kreativ programues arkitektonik, së pari duhet të përcaktohen prioritetet dhe objektivat e projektit apo hulumtimit, vendimet kryesore të projektimit duke përfshirë metodën e ndërtimit, orientimin, sistemet e ndërtimit, sistemet e ujërave dhe të reshurave, ngrohjes dhe ventilimit (HVAC). Premisat nga sistemi do të analizohen veç e veç, duke shkoqitur veçori të cilat do të merren parasysh gjatë gjithë procesit të dizajnit, me aksent në optimalizim dhe efikasitet.

Sipas PER, është e rëndësishme për tu themeluar struktura e ekipeve të punës, të cilat do kërkojnë vijat kryesore apo kornizën, për të gjetur opsionet më optimale:

1. Krijimi i prioriteteve dhe objektivave për qëndrueshmërinë dhe efikasitetin e ndërtesës.

2. Analiza e resurseve, mundësitë dhe kufizimet lokale.

3. Listimi i të gjitha kufizimeve të tjera të projektit, përfshirë buxhetin total, buxhetin e ndërtimit, koha e ndërtimit dhe mirëmbajtjes, teknikat dhe mjeshtëritë të cilat janë në dispozicion, analiza e ciklit të jetës, parametrat vitale dhe kostoja.

4. Një listë e sistemeve të mundshme përdoruese, e teknologjive dhe strategjive për tu përmbushur objektivat e projektit.

5. Identifikimi i përparësive dhe sinergjitë e mundshme në mes të sistemeve, teknologjive dhe burimeve njerëzore.

6. Identifikimi i kufizimeve të mundshme të sistemit të propozuar, teknologjisë dhe strategjisë.

7. Prioritetet e sistemit të propozuar, teknologjive dhe strategjisë.

8. Identifikimi i sistemeve alternative, teknologjive dhe strategjisë.

9. Vlerësimi i elementeve të propozuara me kriteret LEED. 
Në nivelin e legjislacionit, udhëzimeve dhe masave të shtetit të Kalifornisë, të zbatuara aktualisht si model relevant për shtjellimin e temës, do janë:

1. Vendimi dhe akti për ngrohjen globale. Akti 2006 apo California Bill 32 (Nunez, Pavley), drejton udhëzimin e Air California, për rregullimin e emetimeve të gazrave me efekt serrë, duke filluar nga viti 2012.

2. Adaptimi, procesi i ndryshimit të funksioneve në ndërtesat historike, duke $\mathrm{i}$ ruajtur elementet e rëndësishme historike.

3. Albedo, pasqyron raportin e sipërfaqës dhe rrezatimit elektromagnetik, i njohur si reflektim diellor.

4. Biophilia, qasje në arkitekturë, nga ngjashmëria e dukurive biologjike natyrore, si vegjetacioni, pemët, lulet si dhe nga ndryshimet mjedisore klimatike.

5. Dizajni i integruar, proces i projektimit në të cilin një numër i disiplinave dhe aspekteve të ndërlidhura gjatë hartimit të projektit janë të fuzionuara, në një mënyrë që siguron një përfitim sinergjik efikas.

Sipas (Wilson. A, 2001) ${ }^{7}$ në rolin e editorit/botuesit i cili përmbledh hulumtimet që i përkasin dizajnit të integruar, procesit të projektimit të ndërtesës në të cilën involvohën shumë disiplina dhe veçori në dukje të parë të palidhura në mes veti. "Qëllimi është për të arritur performancë të lartë dhe përfitime më të mëdha nga një çmim më i ulët investiv se sa kombinimi i përgjithshëm i të gjithë komponentëve të cilat mund të shihen në fillim."

Ky proces shpesh përfshin strategjinë e integrimit të "dizajnit të gjelbër" nga kriteret konvencionale të dizajnit, formave të ndërtimit, funksioneve dhe kostot e ndërtimit. Ndërmarrje kyçe në projektimin e integruar të ndërtesave është pjesëmarrja e njerëzve nga lëmi të specialiteteve të ndryshme të projektimit: arkitekturës së përgjithshme, HVAC, fazave nga instalimet elektrike dhe ndriçimit, dizajnit të brendshëm, dizajn peisazhor dhe mjedisit. Duke punuar së bashku në pikat kyçe në procesin e projektimit, pjesëmarrësit mund të identifikojnë shpesh zgjidhje projektuese më atraktive ngaqë do të mund ti hasnim në proceset klasike dhe lineare të projektimit. Opsionet dhe përfshirja e projektimit të integruar, dizajni i integruar i ndërtesave mund të jetë pjesë e çdo projekti të objekteve arkitektonike, megjithatë, është më i përshtatshëm për projektimin e ndërtesave të reja ose i rëndësishëm për projekte për renovim të tërësishëm. Dizajni i integruar është më efektiv kur çështjet kryesore trajtohen në fazën e hershme të planifikimit dhe procesit të projektimit. Mundësitë identifikohen më lehtë përmes një procesi të hapur të kërkimit, më lehtë për tu kombinuar dhe zbatuar strategjitë në arritjen e rezultateve. Gjithashtu, nëse ndërtesa është projektuar "në proces klasikë", dhe më pastaj janë aplikuar teknologjitë dhe strategjitë për një çështje të mëvonshme në proces të integruar, rezultatet për t'u integruar janë të dobëta në projektimin e përgjithshëm të ndërtesës, qëllimet dhe rezultatet e fundme me siguri do të jenë të dobëta dhe me të kushtueshme.

7 Eds.Wilson, A. (2001).Greening Federal Facilities. Brattleboro, Vermont : U.S. Department of Energy. 
Në ndërtesat ekzistuese, aftësia për të përmirësuar performancën e ndërtesave me strategjinë e projektimit të integruar si një nga idetë kryesore të rindërtimit të ndërtesës, dhe komponentëve të sistemit mundë të arrihen. Pra, kur ne mendojmë për strategjinë e projektimit të integruar të ndërtesës, që përfshin të gjitha aspektet e "projektimit të gjelbër": përmirësimi i efikasitetit energjetik, planifikimi i qëndrueshëm i mjedisit, ruajtjen e ujit, po ashtu duke krijuar një mjedis të shëndetshëm me theks në përdorimin e materialeve të padëmshme për mjedisin.

Autori, (Wilson, A. 2001) ${ }^{7}$ thekson se procesi i projektimit dhe analizat për zhvillimin e një dizajni të integruar të ndërtesave, duhet të përfshijnë:

1. Krijimi i një skenari bazë. Për shembull, profili i performancës tregon përdorimin e energjisë dhe kostot specifike për objektin që është në përputhje me standardet Federale të energjisë dhe masave të tjera për llojin e projektit, vendndodhjen, madhësinë .

2. Vargu i identifikimit të zgjidhjeve, të cilat kanë potencial për një çështje të veçantë apo projekt.

3. Vlerësimi i efikasitetit të strategjive individuale: një nga një, me anë të analizës apo procesit të eliminimit për parametrat e caktuara.

4. Strategjitë, grupimi i atyre që janë të efikasitetit të lartë, në kombinime apo kombinatorikë të ndryshme, për të vlerësuar performancën.

5. Përzgjedhja e strategjive, përmirësimi i dizajnit me iterimin e solucioneve dhe aplikimi i analizave gjatë gjithë procesit.

Për të gjetur "recetën" e nevojshme për ndërtim, gjatë projektimit nëpërmjet një procesi të integruar mund të jetë e vështirë, dhe në të njëjtën kohë sfiduese dhe tërheqëse. Ekipet e projektimit shpesh gjatë procesit të projektimit bëjnë edhe ndryshime të mëdha që janë efektive dhe kontribuojnë në "performancë të lartë", madje shpesh edhe me çmime shumë rentabile. Megjithatë, gjatë projektimit, ka raste dhe mundësi të mëtejshme kërkimore që nganjëherë mund të kontribuojnë në arritjen e rezultateve të papritura, në të cilën ekipi $\mathrm{i}$ projektimit i thyen pengesat klasike.

" Unë duhet t'ju them se Toka u takon të giithëve... çdo brezi gjatë kohës të ekzistencës së tijë, plotësisht me të drejtat e tyre... Asnjë brez nuk mund të ketë një barrë më të madhe mbi përgjegjshmërinë ndaj mjedisit përveç gjatë kohës së ekzistencës së tijë. "

Thomas Jefferson, 1789.

Kompleksiteti i ndërtesave në zonat urbane është vazhdimisht në rritje, në aspektin e teknologjisë dhe të ndërtimit, shërbimeve dhe sistemeve të infrastrukturës, në këtë mënyrë përbëjnë një arkitekturë multidisiplinare, dhe me qasje në planifikimin urban më shumë se kurrë. Bashkëpunimi dhe komunikimi janë esencial, më së të domosdoshëm për një dizajn të qëndrueshëm. 
Qasja në dizajn të integruar kërkon vullnetin dhe aftësinë e secilit anëtar të ekipit, duke përfshirë arkitektë, inxhinierë, planifikuesit urban dhe sipërmarrësit. Bashkëpunimi i përbashkët i të cilëve kontribuon në gjetjen e zgjidhjeve më të mira. Procesi i projektimit duhet të jetë me pjesëmarrje, dhe përfshinë një shumëllojshmëri të projektimi, duhet të jetë një proces dinamik në mënyrë holistike me të gjitha dimensionet e sistemeve të ndërtimit, duke përfshirë dimensionin e mbrojtjes së mjedisit ".

Në ditët e sotme, termi Arkitekt është përdorur edhe në shumë disiplina të tjera inxhinierie, për projektimin, ndërtimin, mirëmbajtjen dhe renovimin e ndërtesave, me një theks të veçantë në ndikimin e tyre në mjedis.

Në disa gjuhë, termi "arkitekt" është përkthyer fjalë për fjalë si "inxhinier arkitektonik". Ndarja në mes të inxhinierisë, arkitekturës dhe të artit duhet të zhduken, për të lehtësuar zhvillimin dhe evoluimin e njohurive të reja dhe të shprehjes së re arkitektonike. Përdorimi i termit "evoluim" i njohurive të reja arkitektonike është më se aktual dhe bashkëkohor.

Në mënyrë që të harmonizohet integrimi i të gjitha aspekteve të procesit të projektimit, arkitekti apo inxhinieri arkitektonik, duhet të jenë në gjendje të komunikojë dhe të përdorë të njëjtin fjalor me aktorë të ndryshëm të përfshirë në ekipin e projektimit. Megjithatë, pengesa për integrimin e të gjitha aspekteve të procesit të projektimit ende ekziston dhe duhet të tejkalohet.

Andaj konsiderojë se, në lidhje me barrierat ekzistuese për të zbatuar dizajnin apo projektimin e integruar, paraqitet problemi i integrimit të koncepteve të qëndrueshme dhe varet kryesisht nga praktika arkitektonike dhe qasja, infrastruktura ligjore, por gjithashtu kjo është edhe një problem i kulturës së përgjithshme, veçanërisht në aspektin e mungesës së vizionit. Vizioni i arkitektit i referohet arsimimit të tij dhe nivelit të njohurive universale. Ekziston një hendek midis dijes dhe praktikës akademike. Në përgjithësi, çështjet mjedisore që lidhen me çështjet teknike, disa arkitektë besojnë se dominojnë aspektet teknike?

Për fat të keq, ka ende shumë çështje teknike të cilat arkitektët i shohin si kufizime të krijimtarisë dhe lirisë, mirëpo kjo është një sfidë në procesin e projektimit dhe të evoluimit. Arsyeja kryesore për këtë qëndrim është rezultat i nivelit të arsimit akademik dhe atë të përgjithshëm. Hulumtimet tregojnë mënyrat e mundshme për të kapërcyer pengesat ekzistuese, përdorimi i teknologjive të reja duhet të shihet si mundësi për të eksploruar potencialin funksional dhe estetik për kontrollin dhe mbrojtjen e mjedisit. Investitori është gjithmonë në kërkim për përdorim cilësor të hapësirës, natyrisht me koncept të njëjtë është gjithashtu edhe arkitekti. Ndonjëherë është e nevojshme për të rritur ndërgjegjësimin e klientit, të rregullohet raporti ndërmjet kostos dhe përfitimit, duke mos aluduar vazhdimisht vetëm në profit. Aftësia për të zbatuar zgjidhje të favorshme të projektimit të integruar, mund të stimulojë dhe të kontribuojë edhe në konceptin e të kuptuarjes së nivelit kulturor.

Njerëzit nuk i pëlqejnë ndryshimet... Por vazhdimisht janë

duke bërë ndryshime, të shpejta dhe të mjaftueshme, aq sa që shkojnë nga një lloj "normale" tek te tjetra ...

Terry Pratchet, 2008 


\subsubsection{Kërkesat - Popullata}

Sipas projeksioneve të besuara shkencore mendohet se deri në vitin 2050 popullsia do të rritet edhe me 3 miliardë banorë, që në kornizën e përgjithëshme të projektura popullata arin numrin prej 9 miliardë banorë.

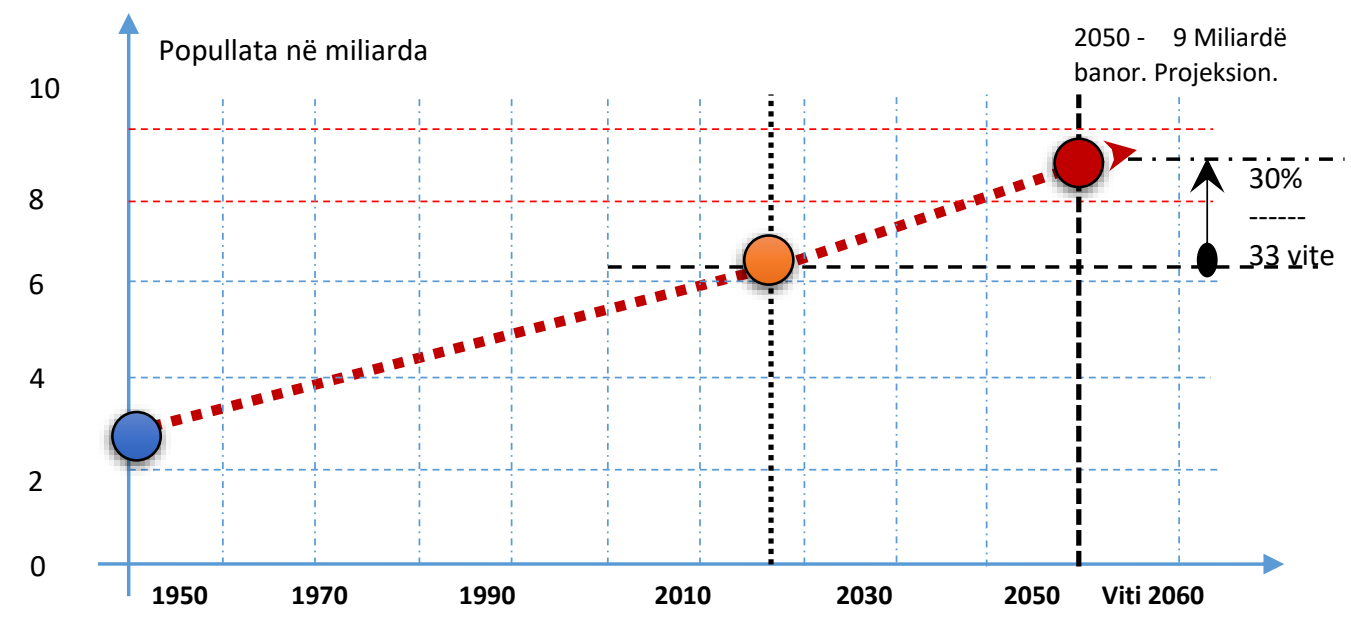

Figura 4. Projeksioni i popullates gjatë dekadave të ardhshme (Burimi): UN. Habitat: World Cities Report, 2016. UN, DESA.

UN. Habitat: Living Planet Report, 2015. Bujar Bajçinovci, 2017.

Kurse, sipas projeksioneve të besuara mendohet se deri në vitin $2050,75 \%$ e njerëzve do të jetojnë në qytete apo në mjedise urbane.

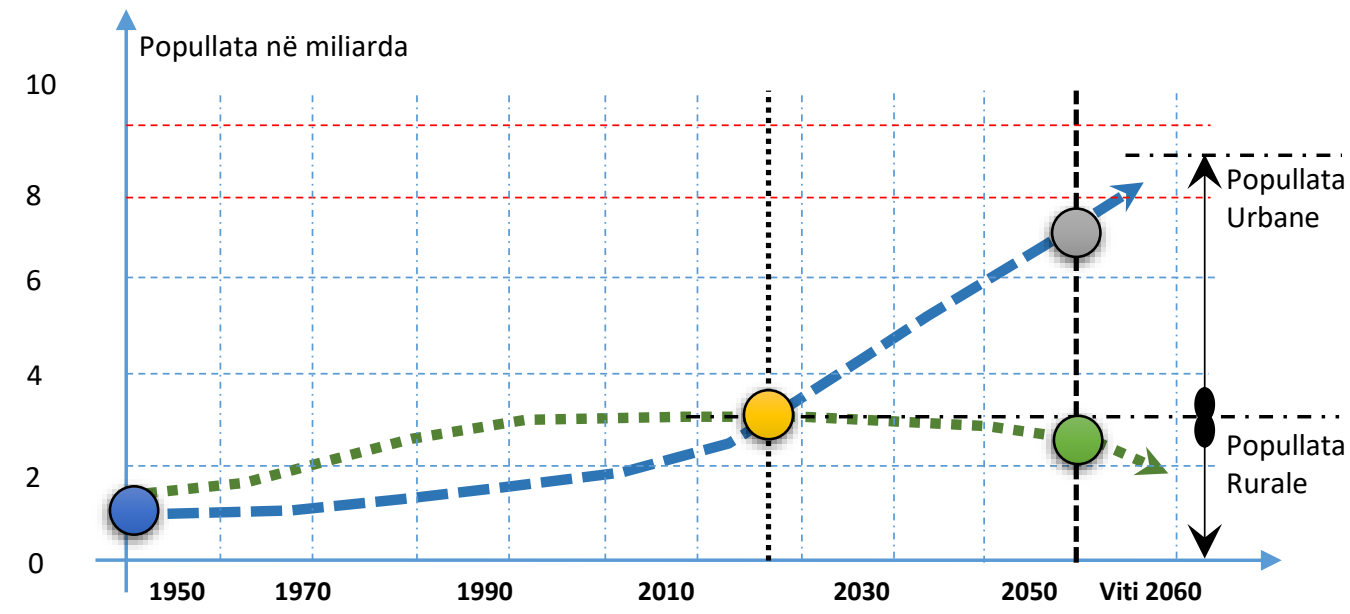

Figura 5. Projeksioni i popullates urbane dhe rurale gjatë dekadave të ardhshme (Burimi): UN. Habitat: World Cities Report, 2016. UN, DESA.

UN. Habitat: Living Planet Report, 2015. Bujar Bajçinovci, 2017. 


\subsubsection{Racionalizimi i kultivimit bujqësor}

Për fuqizim të qëndrueshëm të përkrahjes së fermerëve, duhet vazhdimisht përgatitur masa për mbështetjen e ekonomive bujqësore, e sidomos në rastet kur ndodhin fatkeqësitë natyrore, me dëme serioze në sektorët: drithëra, perimekulturë, serra, pemishtet, fidanishtet, vreshtat. Respektivisht, makineritë dhe ekonomitë bujqësore me prodhimtari blegtorale: kafshët e gjalla, shpezët, bletët, akuakultura-peshku (kultivimi dhe hudhra), objekte prodhuese dhe përcjellëse, si dhe ushqimi i kafshëve.

Tek fermat vertikale vërehet nje racionalizim shumë efikas në raport me fermat e zakonshme, sidomos në ruatjen e resurseve të tokës bujqësore. Për më tepër, të dhënat nga literatura shkojnë aq larg sa që krahasojnë racionalizimin e fermave vertikale në raport 1 me 10 në favor të fermave vertikale, kur bëhet fjalë për racionalizimin e tokës bujqësore në raport me rendimentet e arritura.

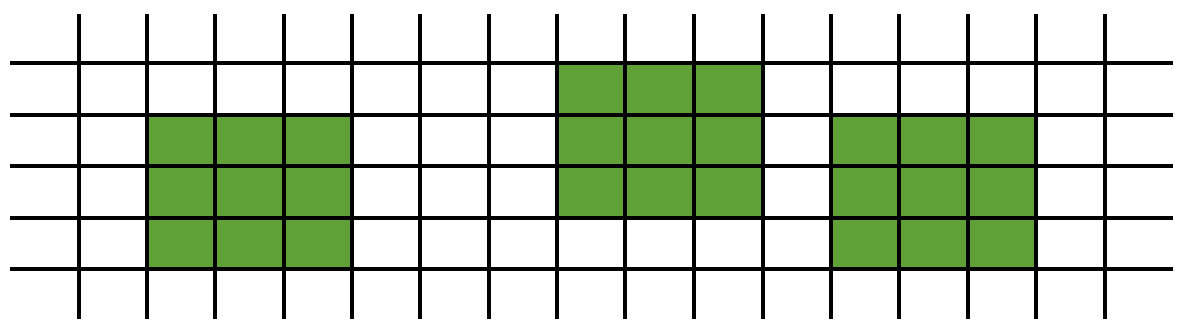

3 ha - Farmë sikurse 0.5 ha - Farmë vertikale në disa raste raporti shkon edhe 1 me 10

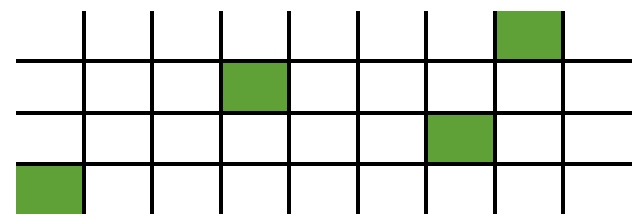

Figura 6. Racionalizimi i tokës bujqësore në raport me rendimentet e pritura (Burimi): Bujar Bajçinovci, 2017.

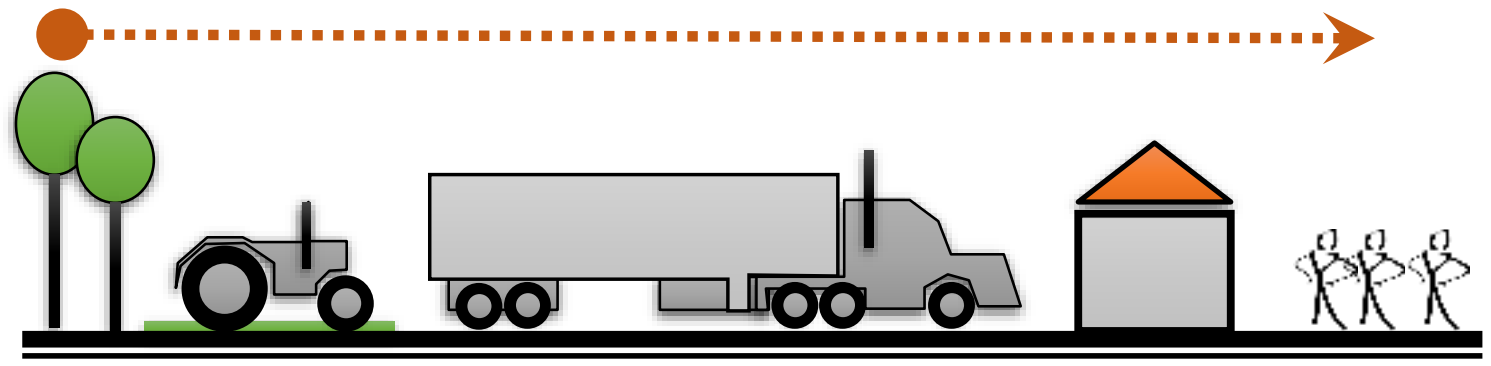

Figura 7. Rrugëtimi jo i qendrueshëm i procesit prodhues tek fermat 'klasike' (Burimi): Bujar Bajçinovci, 2017. 


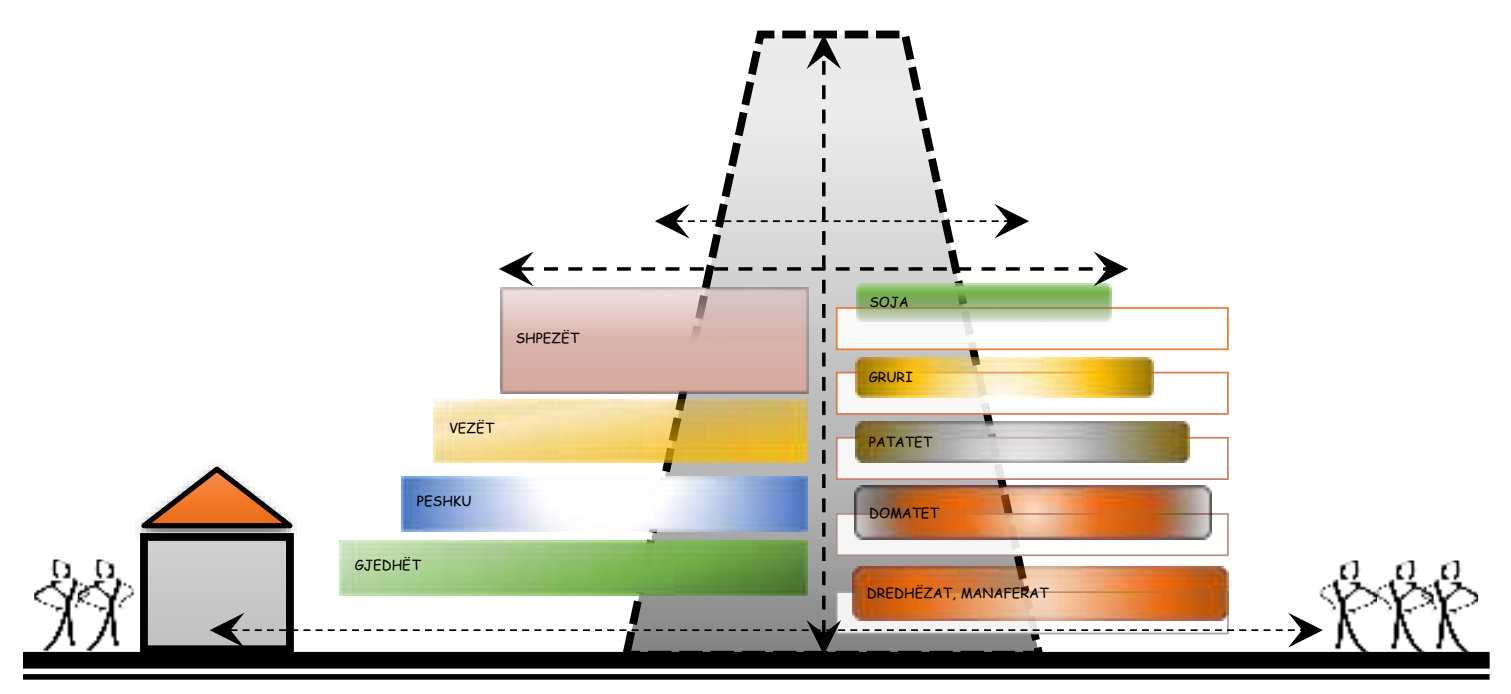

Figura 8. Rrugëtimi i qendrueshëm i procesit prodhues tek fermat vertikale (Burimi): Bujar Bajçinovci, 2017.

\subsection{FERMAT VERTIKALE - PARIMET PROJEKTUESE}

Një pjesë e madhe, pothuajse të gjitha ndërtesa publike dhe individuale të ndërtuara që nga viti 1999 në Kosovë, kanë nevojë për rinovim nga aspekti i efiçiencës së energjisë. Konsumi i energjisë apo humbja termike në këto ndërtesa është veçanërisht i lartë. Prandaj, sa më shumë konsum të energjisë për ngrohje, reflektohet direkt ne emanimet e $\mathrm{CO} 2$. Hulumtimet për qytetet e Komunitetit Evropian, tregojnë sipas studimeve se, objektet individuale dhe përdoruesit e tjerë janë përgjegjës për rreth $35 \%$ të emetimeve të CO2 nga energjia e konsumuar. Prandaj, një qasje më e qëndrueshme në funksion të kost-benefitit, konsumi i energjisë në këtë sektor mund të reduktohet në mënyrë optimale. Në figurën e mëposhtme, paraqitet një strukturë polifunksionale dhe një tërësi urbarkitektonike si shembull studimi në këtë lëmi, kjo strukturë urbane është një projekt kompleks. Kompleksiteti i tillë në vete përfshin elemente të ndryshme të qëndrueshme. Sidomos në qasje, mendim holistik, dhe si një sistem i tërë funksional i mëvetshëm. Masdar ka një sistem unik të pesë njësive të integruara në një tërësi, të cilat janë të strukturuara për të inkurajuar shkëmbimin e njohurive, biznesit dhe ekspertizave të specializuara.

"Si i kemi shfrytëzuar burimet primare të energjisë që furnizojnë qytetet tona, pa kontribut ndaj ndryshimeve klimatike? Si të krijohen teknologji që janë fleksibile dhe që përdorin më pak energji ...? Si të furnizojmë me ujë të pijshëm vendet ku ka reduktime të burimeve të ujit të pijshëm? Si të bëhet rritja ekonomike pa mbështetje kryesore në lëndët djegëse fosile ...? Tani, këto sfida ushtrojnë presion në mbarë botën, por janë veçanërisht të dukshme këtu në Gjirin Arabik. Ne e dimë se furnizimi i naftës është në rënie, burimet ujore janë në rënie. Strategjia e vjetër për zhvillim, prosperitet dhe rritje ekonomike nuk do të funksionojë më."8

8 Clinton, R. H.(2011).US. Secretary of State, addresses the Masdar Institute. 
Gjendja aktuale e sektorit të bujqësisë dhe blegtorisë apo strukturave përcjellëse është e tillë që ai është një konsumator i madh i energjisë, konsumues i madh i burimeve natyrore. Si nga agroindustria, apo vetë kultivimi si koncept prodhues është gjenerator substancial i fitimeve financiare. Megjithatë, gjersa po ndërtojmë në të njëjtën kohë jemi duke krijuar një ndikim të caktuar në mjedis, në resurset e energjisë, industrisë ekstraktive, tokës bujqësore, ujit dhe burimeve të tjera natyrore. Sipas hulumtimit aktual, konsumi i përgjithshëm i energjisë në sektorin e ndërtimit është rreth 50-60\%. Natyrisht, për të pasur një mjedis të qëndrueshëm, ka shumë për tu bërë dhe për tu reduktuar ndikimet negative mjedisore.

Nevoja për të përmirësuar performancën e objekteve është detyrë imediate e projektuesve dhe dizajnerëve në raport me vetën, komunitetin dhe klientin. Pra, paraqitët nevoja për të zhvilluar një sistem të matjes së efikasitetit, në mënyrë që efiçienca mund të vlerësohet dhe të ketë përmirësime të vazhdueshme duke promovuar kosto rentabile, kohëzgjatjen, e ndërtimit, mirëmbajtjen efikase, fleksibilitetin, rivitalizimin dhe arritjen $\mathrm{e}$ performancës së mirëfilltë. Qëndrueshmëria arkitektonike kërkon një kuptim të sofistikuar të aspekteve natyrore, funksionale, sociale, kulturore dhe mjedisore. Është përgjegjësi e secilit arkitekt, të deklarohet hapur në lidhje me ndërgjegjësimin ekologjik dhe të promovojë ruajtjen e mjedisit.

\subsubsection{Konceptet kompozicionale të fermave bashkëkohore urbane}

Në përgjithësi sipas konceptit urb-arkitektonik, fermat në lartësi mund të ndahen në këto tre grupe:

1. Fermat urbane;

2. Fermat urbane etazhore;

3. Fermat vertikale.

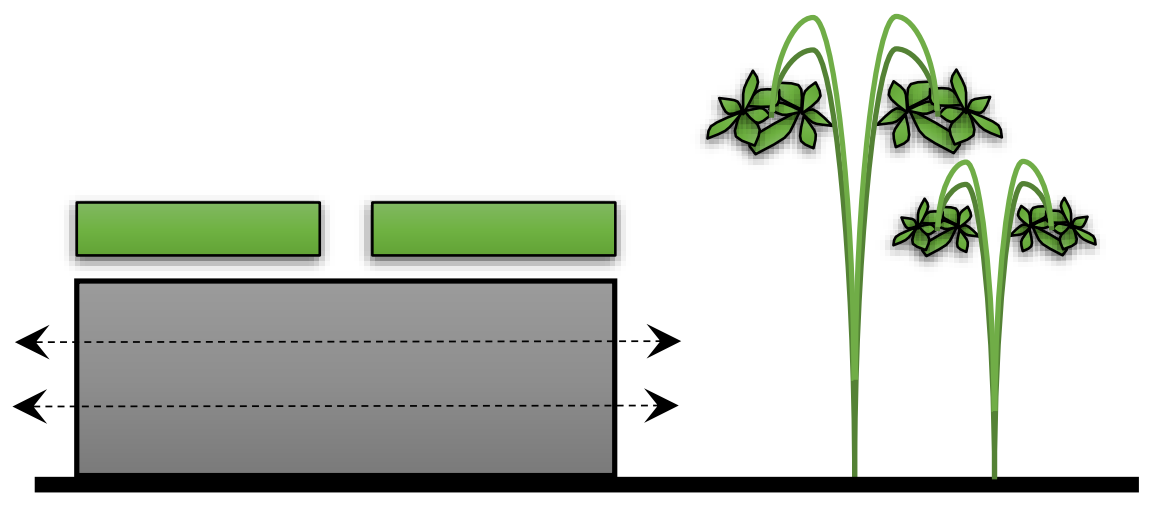

Figura 9. Fermat Urbane

(Burimi): Bujar Bajçinovci, 2017. 


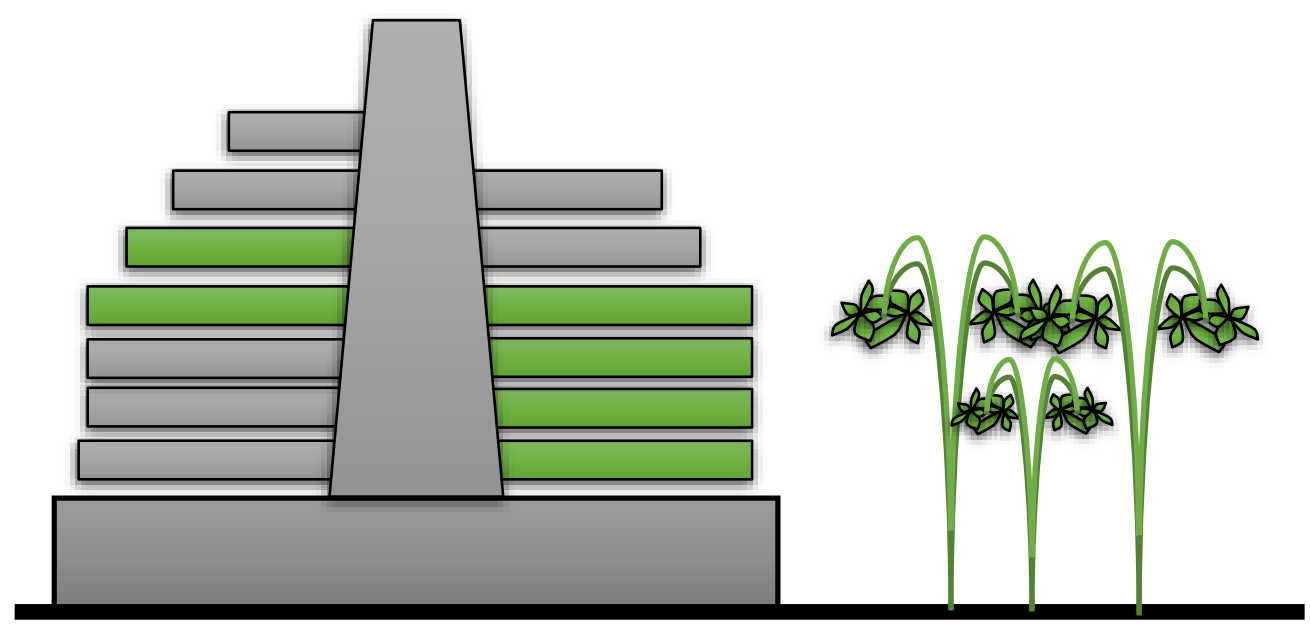

Figura 10. Fermat Urbane etazhore

(Burimi): Bujar Bajçinovci, 2017.

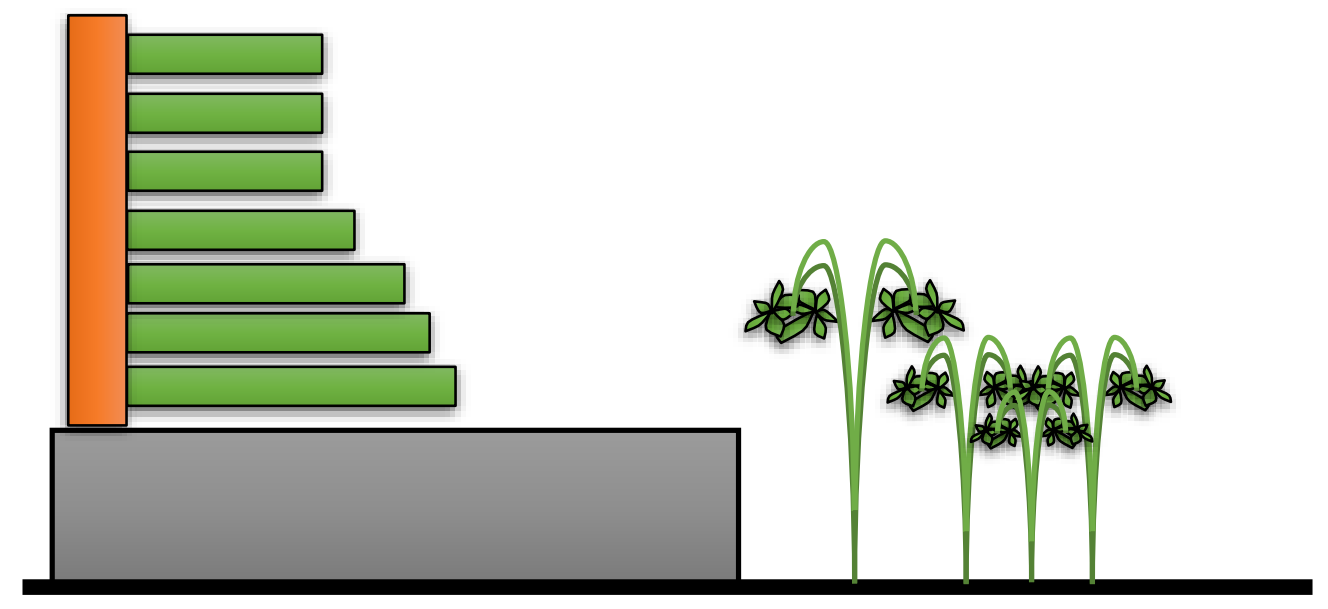

Figura 11. Fermat vertikale

(Burimi): Bujar Bajçinovci, 2017.

\subsubsection{Ndryshimet klimatike}

"Ekzistojnë përkufizime të ndryshme për klimën, sipas Konrad, V. (1936) klima definohet si gjendje mesatare e atmosferës mbi një vend të caktuar për një periudhë të caktuar kohore, duke përfshirë lëkundjet mesatare dhe ekstreme apo të skajshme."9 Ndryshimi klimatike janë një nga çështjet më të rëndësishme që e karakterizojnë këtë shekull, ndër atributet më të vështira të ndryshimeve klimatike pritet të rritet intensiteti dhe ngjarjet ekstreme të motit, duke përfshirë përmbytjet dhe thatësirat, më shumë stuhi të dhunshme, valë më intensive të ngrohjes dhe përshkallëzim i mundshëm në konflikte për ushqim dhe resurse ujore.

9 Pllana, R. (2015) Klima e Kosovës. ASHAK, Prishtinë. 
Masat për ndryshimet klimatike duhet të zhvillohen në fronte të gjera, është e nevojshme që të përfshihet adaptim dhe zbutje në të njëjtën kohë. Gjysma e popullsisë së botës jeton në zonat urbane, dhe kjo pjesë është duke u rritur vazhdimisht, duke u parashikuar që rritja të arrin në $60 \%$ deri në vitin 2030.

Qytetet konsumojnë shumicën e të gjithë resurseve, 60-75\% të prodhimit të energjisë në botë, duke u llogaritur se kjo është përafërsisht vlera kryesore e emetimeve të $\mathrm{CO}_{2}$ në nivel global.Hulumtimet e kryera nga (OECD, 2010) tregojnë se stabiliteti dhe prosperiteti i qyteteve mbështeten në infrastruktura të mëdha të rrjetit që ofrojnë shërbime fondamentale, hedhja e mbeturinave të ngurta, trajtimi i ujërave të zeza, transporti, uji i pijshëm, energjia dhe sistemet e sanitacionit, të gjitha këto shërbime jetike, kanë ndikim të madh në mjedisin lokal dhe global. Jo vetëm që këto dukuri shpesh tregojnë efekte jo lineare dhe kumulative, efektet negative në mjedis rezultojnë në humbjen e pakthyeshme të vlerës ekologjike (OECD, 2008). Përkeqësimi i sistemeve të infrastrukturës së krijuar, jo efikasiteti dhe ngadalësimi i përparimit të përgjithshëm, imponon kosto shtesë në ekonominë lokale dhe kombëtare. Infrastruktura urbane është projektuar zakonisht për ti trajtuar ngjarjet "normale", veçanërisht në vendet në zhvillim (Hallegatte et al., 2010). ${ }^{10}$ Edhe pse infrastruktura e qytetit është një nga atributet dhe elementet jetike për funksionimin e qyteteve, qytetet në shumë pjesë të botës janë duke luftuar për ti plotësuar nevojat bazike të popullsisë së tyre, kanë burime të kufizuara dhe vështirë përshtaten me ndryshimet klimatike (Ruth et al,. 2006).

Tabela 17. Popullsia e botës sipas madhësisë të vendbanimeve, 2016 dhe 2030 (Burimi): UN. Habitat: World Cities Report, 2016. Bujar Bajçinovci, 2017.

\begin{tabular}{l|c|c|c|c|c|c}
\hline & \multicolumn{3}{|c|}{2016} & \multicolumn{3}{c}{2030} \\
\hline & $\begin{array}{c}\text { Numri i } \\
\text { vendban. }\end{array}$ & $\begin{array}{c}\text { Populata } \\
\text { (milion) }\end{array}$ & $\begin{array}{c}\text { Përqindja } \\
\text { popullata } \\
\text { Bota }\end{array}$ & $\begin{array}{c}\text { Numri i } \\
\text { vendban. }\end{array}$ & $\begin{array}{c}\text { Populata } \\
\text { (milion) }\end{array}$ & $\begin{array}{c}\text { Përqindja } \\
\text { popullata } \\
\text { Bota }\end{array}$ \\
\hline Vendbanime Urbane &.. & 4034 & 54.5 &.. & 5058 & 60.0 \\
\hline 10 milion-më shumë & 31 & 500 & 6.8 & 41 & 730 & 8.7 \\
\hline 5 to 10 milion & 45 & 308 & 4.2 & 63 & 434 & 5.2 \\
\hline 1 to 5 milion & 436 & 861 & 11.6 & 558 & 1128 & 13.4 \\
\hline 500 000 - 1 milion & 551 & 380 & 5.1 & 731 & 509 & 6.0 \\
\hline Më pak se 500 000 &.. & 1985 & 26.8 &.. & 2257 & 26.8 \\
\hline Vendbanime Rurale &.. & 3371 & 45.5 &.. & 3367 & 40.0
\end{tabular}

Mënyra se si njerëzit qarkullojnë nëpër qytet, zhvillimi i pakontrolluar urban, sasia e energjisë që njerëzit e përdorin në shtëpi për ngrohje, rezulton se qytetet janë konsumatorët më të mëdhenj të energjisë dhe njëherit ndotësit më të mëdhenj. Zonat urbane janë duke u bërë më të dendura dhe më shumë mbështeten në transportin publik, emisionet e dyoksidit të karbonit janë duke u rritur. Gjithashtu, jo të gjitha qytetet, njëjtë në të gjitha shtetet ose vendet në të njëjtin kontinent kontribuojnë në emisionet e dyoksidit të karbonit. Niveli i emisioneve ndryshon gjerësisht brenda vendit, pjesërisht për shkak të dallimeve nga dendësia urbane dhe zhvillimore. ${ }^{10}$

10 OECD (2010), Cities and Climate Change. Paris, France : OECD Publishing. 
Tabela 18. Qytetet sipas numrit të banorëve, 2016 dhe 2030

(Burimi): UN. Habitat: World Cities Report, 2016. Bujar Bajçinovci, 2017.

\begin{tabular}{|c|c|c|c|c|}
\hline & Qyteti - Shteti & $\begin{array}{l}\text { Popullata } \\
\text { në } 2016 \\
\text { (në mija) }\end{array}$ & Qyteti - Shteti & $\begin{array}{l}\text { Popullata } \\
\text { në } 2030 \\
\text { (në mija) }\end{array}$ \\
\hline 1 & Tokyo, Japan & 38140 & Tokyo, Japan & 37190 \\
\hline 2 & Delhi, India & 26454 & Delhi, India & 36060 \\
\hline 3 & Shanghai, China & 24484 & Shanghai, China & 30751 \\
\hline 4 & Mumbai (Bombay), India & 21357 & Mumbai (Bombay), India & 27797 \\
\hline 5 & São Paulo, Brazil & 21297 & Beijing, China & 27706 \\
\hline 6 & Beijing, China & 21240 & Dhaka, Bangladesh & 27374 \\
\hline 7 & Ciudad de México (Mexico City), Mexico & 21157 & Karachi, Pakistan & 24838 \\
\hline 8 & Kinki M.M.A. (Osaka), Japan & 20337 & Al-Qahirah (Cairo), Egypt & 24502 \\
\hline 9 & Al-Qahirah (Cairo), Egypt & 19128 & Lagos, Nigeria & 24239 \\
\hline 10 & New York-Newark, USA & 18604 & Ciudad de México (Mexico City), Mexico & 23865 \\
\hline 11 & Dhaka, Bangladesh & 18237 & São Paulo, Brazil & 23444 \\
\hline 12 & Karachi, Pakistan & 17121 & Kinshasa, Democratic R. Congo & 19996 \\
\hline 13 & Buenos Aires, Argentina & 15334 & Kinki M.M.A. (Osaka), Japan & 19976 \\
\hline 14 & Kolkata (Calcutta), India & 14980 & New York-Newark, USA & 19885 \\
\hline 15 & Istanbul, Turkey & 14365 & Kolkata (Calcutta), India & 19092 \\
\hline 16 & Chongqing, China & 13744 & Guangzhou, Guangdong, China & 17574 \\
\hline 17 & Lagos, Nigeria & 13661 & Chongqing, China & 17380 \\
\hline 18 & Manila, Philippines & 13131 & Buenos Aires, Argentina & 16956 \\
\hline 19 & Guangzhou, Guangdong, China & 13070 & Manila, Philippines & 16756 \\
\hline 20 & Rio de Janeiro, Brazil & 12981 & Istanbul, Turkey & 16694 \\
\hline 21 & Los Angeles-Long Beach-Santa Ana, USA & 12317 & Bangalore, India & 14762 \\
\hline 22 & Moskva (Moscow), Russian Federation & 12260 & Tianjin, China & 14655 \\
\hline 23 & Kinshasa, Democratic R. Congo & 12071 & Rio de Janeiro, Brazil & 14174 \\
\hline 24 & Tianjin, China & 11558 & Chennai (Madras), India & 13921 \\
\hline 25 & Paris, France & 10925 & Jakarta, Indonesia & 13812 \\
\hline 26 & Shenzhen, China & 10828 & Los Angeles-Long Beach-Santa Ana, USA & 13257 \\
\hline 27 & Jakarta, Indonesia & 10483 & Lahore, Pakistan & 13033 \\
\hline 28 & Bangalore, India & 10456 & Hyderabad, India & 12774 \\
\hline 29 & London, United Kingdom & 10434 & Shenzhen, China & 12673 \\
\hline 30 & Chennai (Madras), India & 10163 & Lima, Peru & 12221 \\
\hline 31 & Lima, Peru & 10072 & Moskva (Moscow), Russian Federation & 12200 \\
\hline 32 & & & Bogotá, Colombia & 11966 \\
\hline 33 & & & Paris, France & 11803 \\
\hline 34 & & & Johannesburg, South Africa & 11573 \\
\hline 35 & & & Krung Thep (Bangkok), Thailand & 11528 \\
\hline 36 & & & London, United Kingdom & 11467 \\
\hline 37 & & & Dar es Salaam, U.R. of Tanzania & 10760 \\
\hline 38 & & & Ahmadabad, India & 10527 \\
\hline 39 & & & Luanda, Angola & 10429 \\
\hline 40 & & & Thành Pho Ho Chí Minh. Viet Nam & 10200 \\
\hline 41 & & & Chengdu, China & 10104 \\
\hline
\end{tabular}

\subsubsection{Sistemet e kultivimit të bimësisë në fermat vertikale}

Në përgjithësi sipas metodes së kultivimit të bimësisë, fermat vertikale mund të ndahen në këto tre grupe:

1. Fermat me sistem Aeroponics;

2. Fermat me sistem Hydroponics;

3. Fermat me sistem Aquaponics. 


\subsubsection{Fermat me sistem Aeroponics}

AEROPONICS. Administrata Kombëtare për Aeronautike dhe Hapësirë (NASA) është pioniere për zhvillimin e kësaj teknologjie inovative e kultivimit të brendshëm të bimësisë. Që nga vitet 1990, NASA ishte e interesuar të gjejë mënyra efikase për të rritur bimët në hapësirë, "aero- ponics", e definuar si kultivim bimësh në një mjedis pa tokë dhe me përdorim shumë të vogël të ujit.

Sistemet e aeroponike akoma nuk kanë përdorim të mjaftueshëm në farmat vertikale, megjithatë, ato tërheqin interes të rëndësishëm. Një sistem aeroponik është shumë efikas i kultivimit të bimëve në fermat vertikale, duke përdorur deri në $90 \%$ më pak ujë sesa sistemet më efikase hidroponike.

Bimët e rritura në këto sisteme janë treguar të marrin më shumë minerale dhe vitamina duke i bërë bimët më të shëndetshme dhe potencialisht më ushqyese. AeroFarms, biznesi kryesor i bujqësisë me kultivim vertikal në Shtetet e Bashkuara, aktualisht është duke ndërtuar fermën më të madhe vertikale në New Jersey (Birkby, 2016).

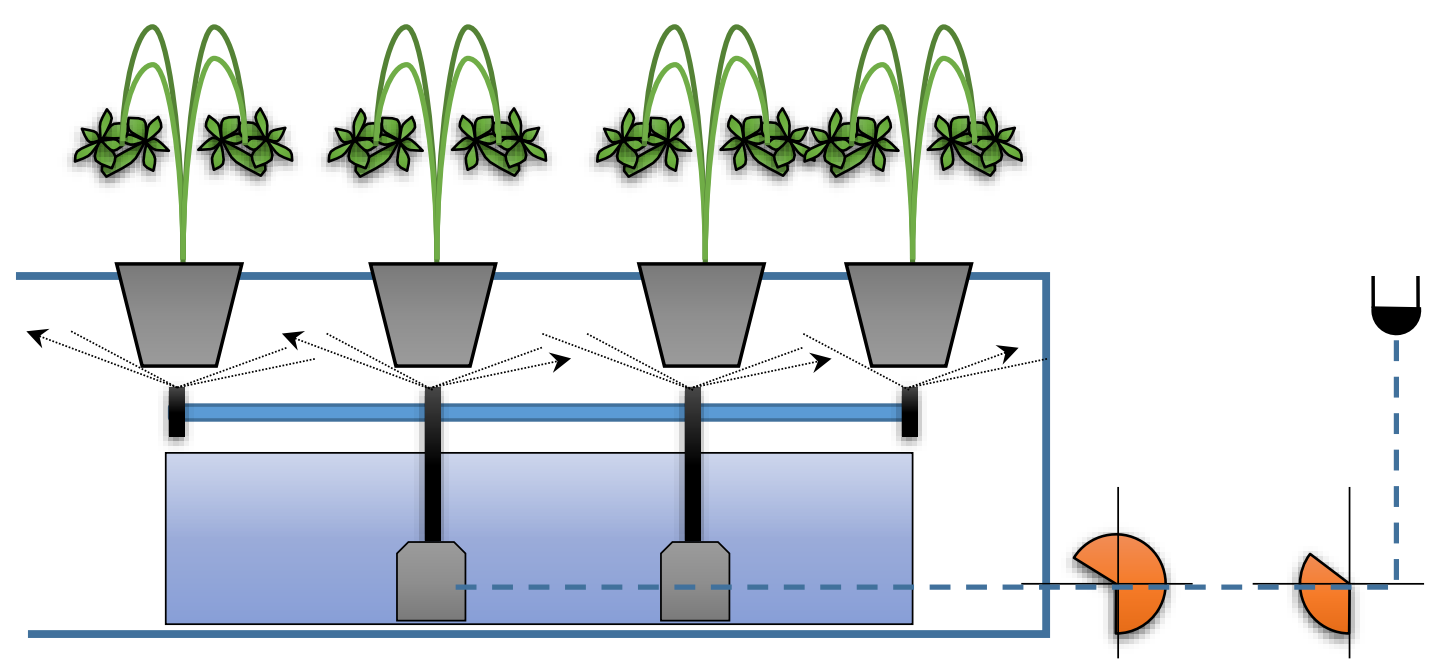

Figura 12. Sistem - "Aeroponics"

(Burimi): Birkby, J. (2016). Vertical Farming. NCAT. Rivizatuar: Bujar Bajcinovci, 2017.

\subsubsection{Fermat me sistem Hydroponics}

HYDROPONICS. Sistemi dominant në kultivim tek fermat vertikale.

Sistemi hydroponics përfshin kultivimin e bimëve me lëndë ushqyese të cilat nuk kërkojnë deposol apo tokë. Rrënjët e bimëve janë të zhytura në lëndë ushqyese, të cilat shpesh mbikëqyren dhe mirëmbahen për të siguruar përbërjen kimike të duhur (Birkby, 2016). 


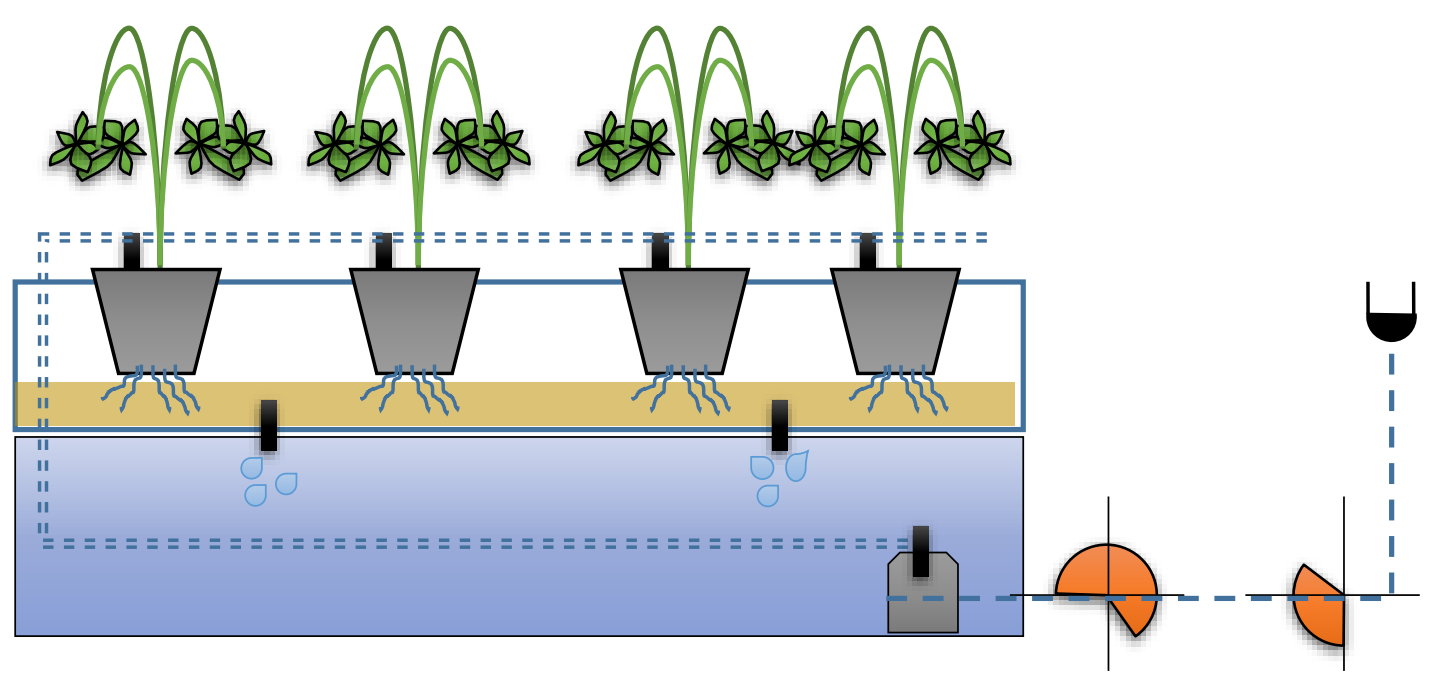

Figura 13. Sistem - "Hydroponics"

(Burimi): Birkby, J. (2016). Vertical Farming. NCAT. Rivizatuar: Bujar Bajcinovci, 2017.

\subsubsection{Fermat me sistem Aquaponics}

AQUAPONICS. Sistemi aquaponic zhvillon sistemin hydroponic një hap më tej, duke kombinuar kultivimin e bimëve dhe peshqëve në të njëjtin ekosistem. Peshqit rriten në pellgje të brendshme, prodhojnë dromca të pasura me lëndë ushqyese që pastaj përdoren si ushqim për bimët në fermën vertikale. Bimët, nga ana tjetër, filtrojnë dhe pastrojnë mbeturinat, të cilat riciklohen në pellgjet e peshqve. Edhe pse aquaponics përdoret në fermat bujqësore vertikale në shkallë më të vogël, shumica e sistemeve komerciale të fermave vertikale fokusohen në prodhimin e disa kulturave të perimeve me rritje të shpejtë dhe nuk përfshijnë pajisje të aquaponics, realisht kjo lehtëson çështjet e prodhimit ekonomik dhe maksimizon efikasitetin. Megjithatë, sistemet e reja të standardizuara të aquaponic mund të promovojnë që sistemi i ciklit të mbyllur të jetë më profitabil (Birkby, 2016).

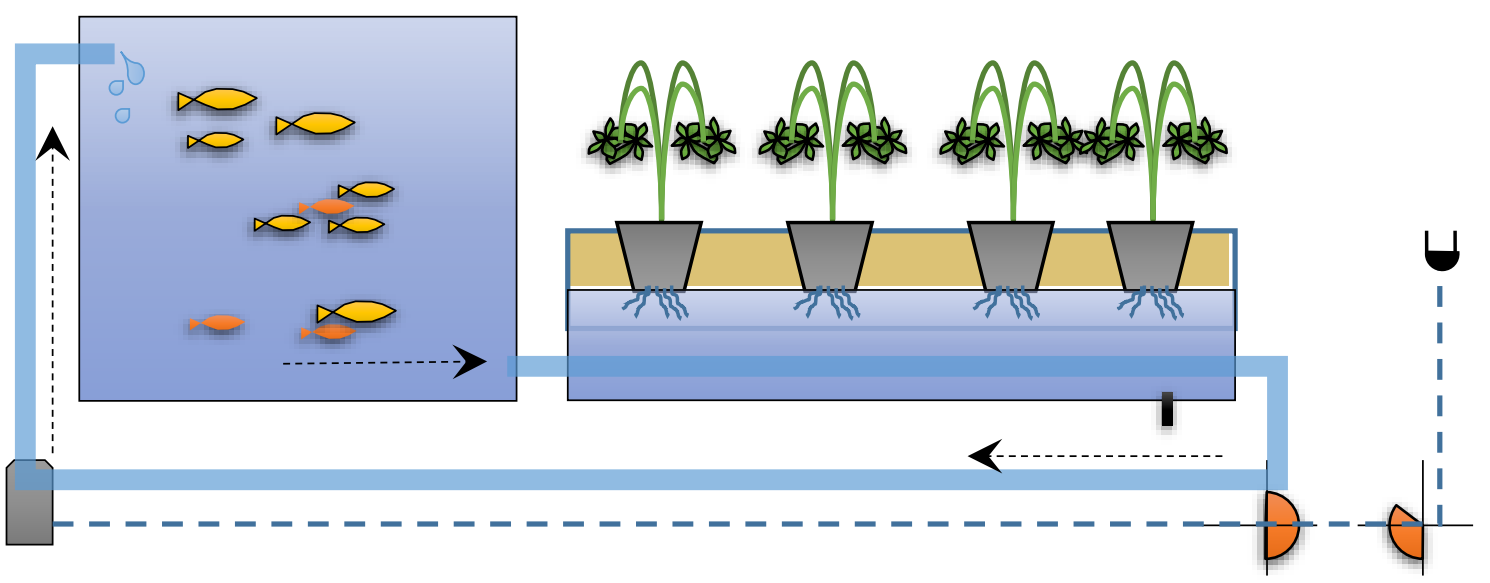

Figura 14. Sistem - "Aquaponics"

(Burimi): Birkby, J. (2016). Vertical Farming. NCAT. Rivizatuar: Bujar Bajcinovci, 2017. 


\subsubsection{Strukturat kompozicionale arkitektonike - fermat vertikale}

Që nga gjeneza kemi raste të lashta dhe mrekulli të krijuara nga nevoja, një arkitekturë krijuese, bashkëkohore, në të gjithë shekujt e evoluimit? Kolonitë nëntokësore të milingonave që të gjitha së bashku shtrihen sa muri i madh i Kines, struktura termitesh të cilat në proporcion më madhësinë e tyre janë gati dy herë më të larta se sa Burj Al Arab, Dubai (rrokaqiell i njohur dhe i lartë). Strukturë ndërtuese, tumë me funksione të veçanta organizative, duke involvuar principet bioklimatike projektuese, e projektuar nga arkitektët e "vegjël".

Gjersa disa lloje të termiteve jetojnë në shtëpitë tona, të tjerët ndërtojnë struktura të veçanta dhe shtëpitë e tyre, disa nga strukturat më mbresëlënëse në botën shtazore. Kodrinat (Tumat) janë qytete termitesh të cilat janë përgjithmonë në zhvillim, të bëra nga materialet e thjeshta organike. Funksionojnë duke punuar në mënyrë të pavarur, pa ndonjë mjet reference, ata mbajnë temperaturën e kontrolluar në mjedis, që përfshinë ventilimin dhe sistemin e ftohjes me dhoma të specializuara për ruajtjen e ushqimit, përmbajnë kopshte fungale, mbajnë vezë dhe e kanë pallatin për mbretëreshën. Si koloni, ata janë në gjendje për të krijuar mjedis apo arkitekturë që tejkalon kapacitetet e tyre individuale (Bajçinovci, 2017).

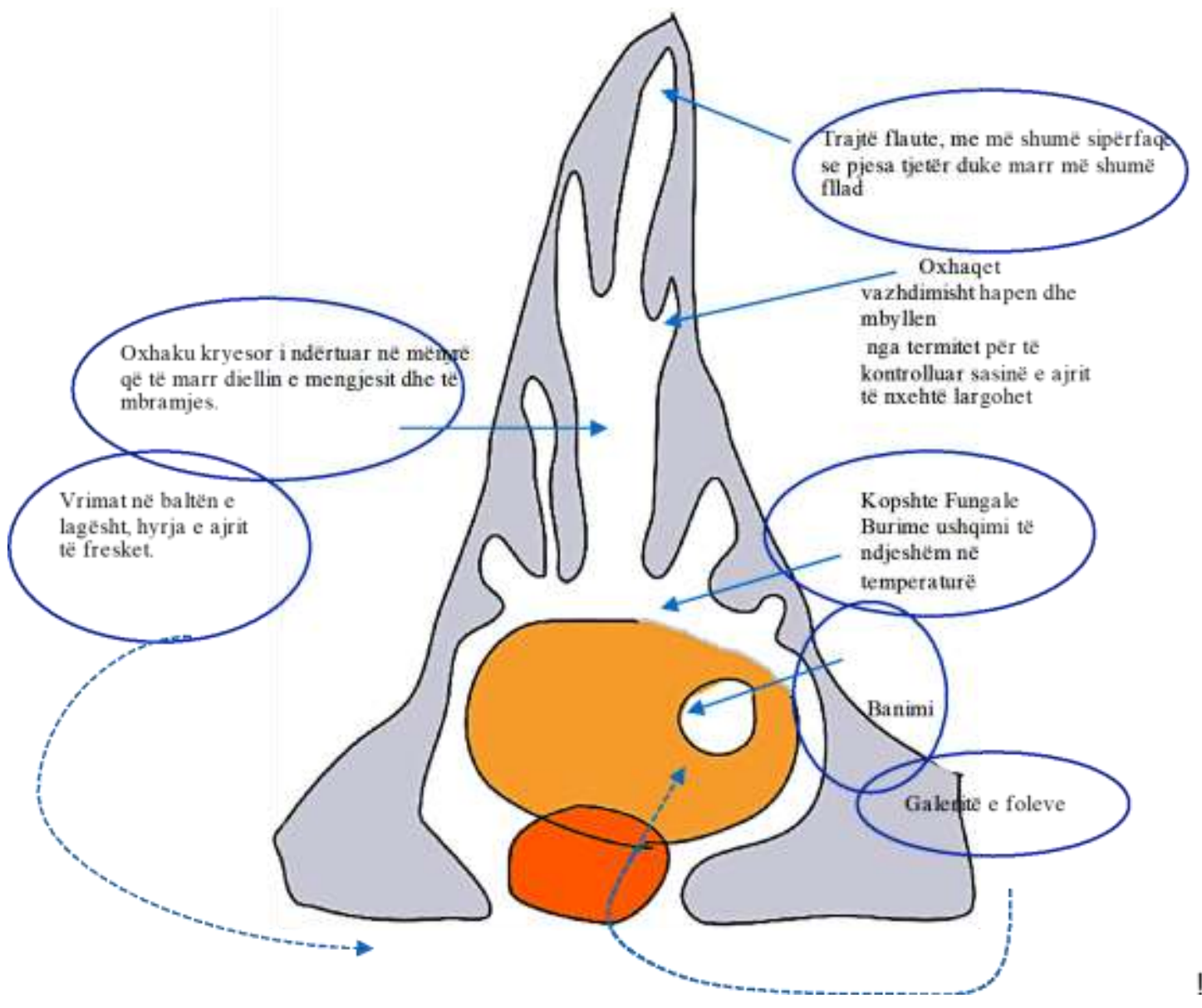

Figura 15. Tumë termitesh, struktura e brendshme organizative. (Burimi): Bujar Bajçinovci. 2015. 
Është jashtëzakonisht e rëndësishme që të investohet kohë e mjaftueshme dhe analiza të thukëta në zgjedhjen e një vendi për ndërtesën, objekti duhet përfituar nga pasuritë natyrore si dielli, era, reliefi i tokës, disponueshmëria e resurseve të ujit, vizurave dhe nga komuniteti. Vizurat dhe orientimi, akset kardinale të botës janë veçori të rëndësishme për mundësitë e peizazhit, duke përdorur pemë, impiante "brisoley" për mbrojtje nga drita, ftohje, mbrojtje nga erërat (Bajçinovci, 2017).

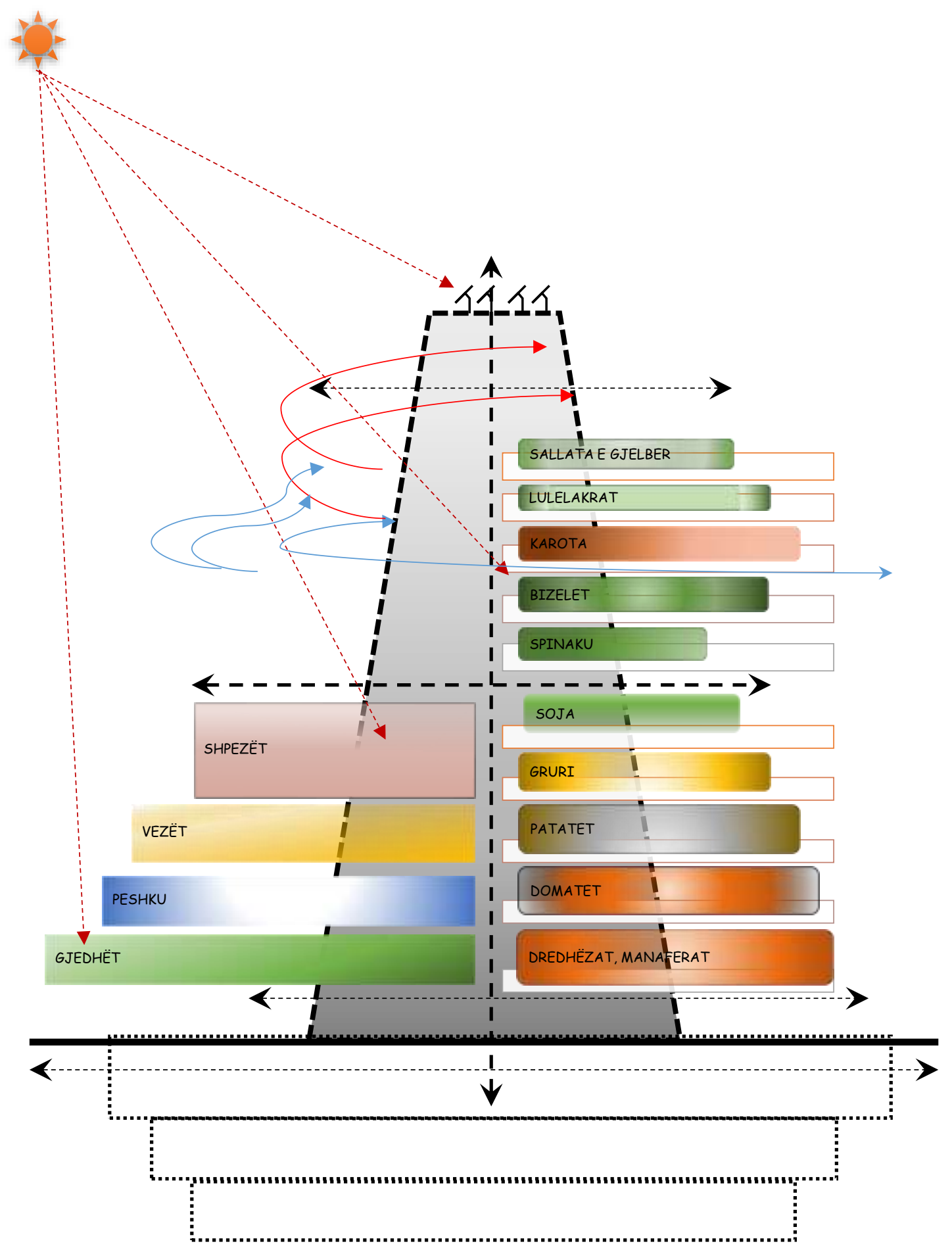

Figura 16. Kultivimi i bimësisë në vertikale (Burimi): Bujar Bajcinovci, 2017. 
Për të projektuar objekt të performancës së lartë, duhet së pari caktuar objektivat konkrete dhe të aplikohet një proces i integruar i projektimit. Një simbiozë ndërmjet funksionit, kërkesave njerëzore dhe rentabilitetit. Zakonisht përdorimi i energjisë është ndikimi më i madh mjedisor, atëherë, metoda dhe strategjia për një ndërtesë me përdorim efiçient të energjisë është një objektiv i cili është gjithnjë e më aktual dhe obligativ.

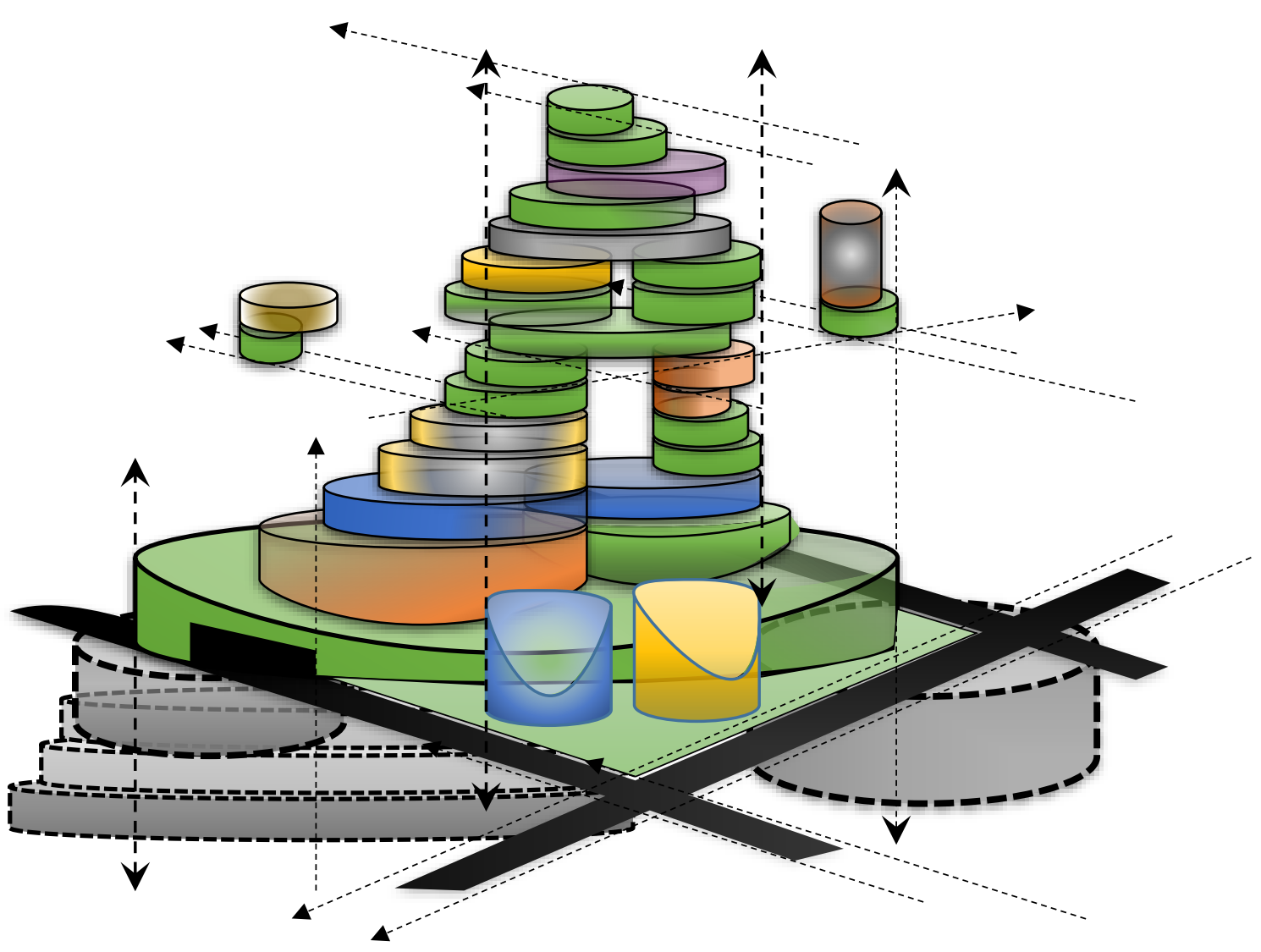

Figura 17. Struktura kompozicionale e një farme vertikale, hibridizimi i funksioneve (Burimi): Bujar Bajcinovci, 2017.

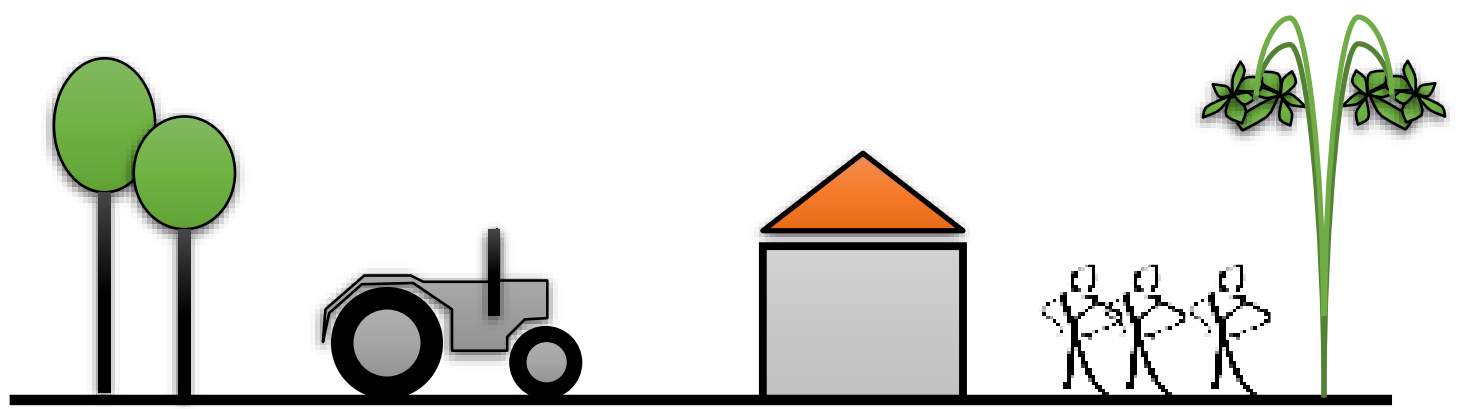

Figura 18. Prodhimi i produkteve ushqimore bio (Burimi): Bujar Bajcinovci, 2017. 
KJO FAQE ËSHTË LËNË QËLLIMISHT E ZBRAZËT! 


\section{MEGASTRUKTURAT HIBRIDE}

\subsection{HIBRIDIZIMI}

○ ersa bota vazhdon të zhvillohet në të gjitha sferat, po ashtu edhe popullsia

J vazhdon të rritet me të. Andaj nga aspekti i dinamikës urbane si dhe arkitekturës së qëndrueshme paraqitën sfida të cilat janë të natyrës së re. Natyrisht që në këtë drejtim duhet dhënë përgjigje, ndaj vëçorive të këtyrë sfidave. Nga aspekti urban apo të prijektimit urban së pari kemi kërkesa për banim, në vazhdim, kemi kërkesa për: zona me afarizëm tregtare, me zona të gjelbra, kujdes të shtuar ndaj mjedisit. Të gjitha këto kërkesa aktuale po reflektohen me fenomene të cilat duhët dhënë përgjigje adekuate, duke përfshirë edhe apo sidomos projektimin e ndërtesave të cilat janë të përziera në funksion. Andaj, si rjedhojë do të ketë nevojë për një projektimin të apo ridefinim të koncepteve projektuese të aplikuara deri më tani. Në këtët drejtim duhet dhënë kujdes të veçantë ndaj ndërtesave hibride të ashtu quajtura. Çfarë janë ndërtesat hibride? Çfarë paraqesin (Bajçinovci, 2017).

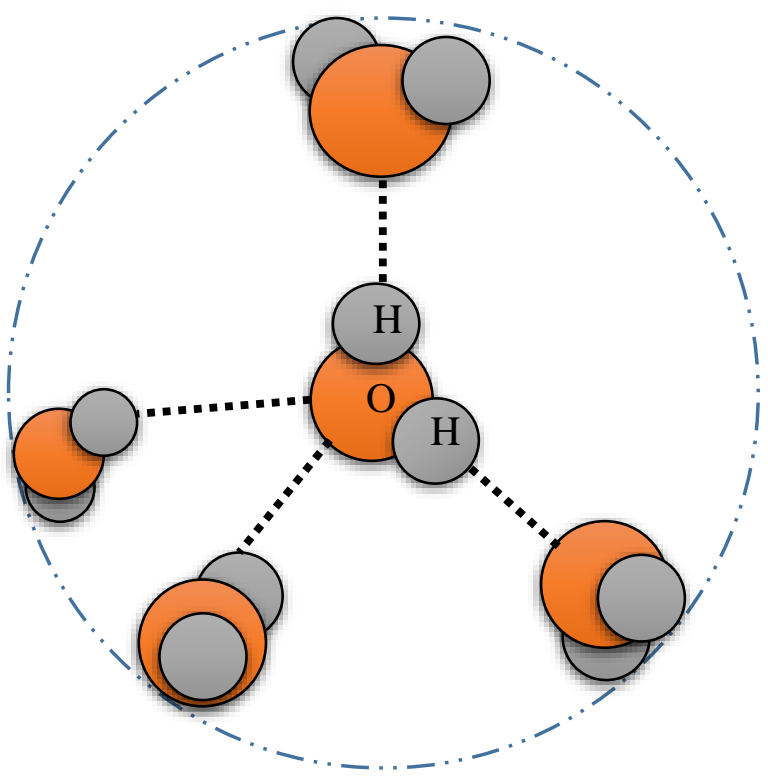

Figura 19. Modeli i lidhjes së hidrogjenit, në ujë

(Burimi): Bujar Bajcinovci, 2017. EJTD Vol. 5, (2). 2017.

Aktualisht, potenciali për ndërtesat hibride ka marrë hov si koncept, në relacion dhe si rjedhojë i zhvillimit ekonomik, mungesa e sipërfaqeve të lira të tokës së bashku me kërkesë është rritur vlera e tokës, rritja dhe zhvillimi i zonave ekonomike, stili bashkëkohor i jetesës, trendi aktual, koncepti i vlerës. Kjo rritje e tendencave të reja në mesin e arkitektëve kanë rezultuar që të gjitha këto sfida projektuese të bëjnë rishfaqjen e ndërtesave hibrid, hibrid, një term në potencë si "shuma e të gjitha pjesëve" apo funksione të përziera në një ndërtesë. 
Joseph Fenton beson se ka një ndryshim në mes të funksionit të përzier dhe ndërtesave hibride. Ndërtesat hibride mund të krahasohen me kodin gjenetik të kryqzuar të specieve të ndryshme. Së bashku erdhi zhvillimin e çelikut dhe ashensorë që lejoi ndërtimin e rrokaqiejt. Këto ndërtesa paraqitën me shumë funksione të bashkuara, asnjë hërë me një funksion të vetëm. Po ashtu Fenton deklaronte se ndërtesat hibride u shfaqen në fillim të shekullit të 20 si një përpjekje për të rigjallëruar qytetet amerikane dhe zgjidhjen e përdorimit të tokës. Gjithashtu duhet theksuar se erdhi koha për një ndërtesë e cila do të transformonte marrëdhëniet midis funksioneve të ndryshme (Bajçinovci, 2017).
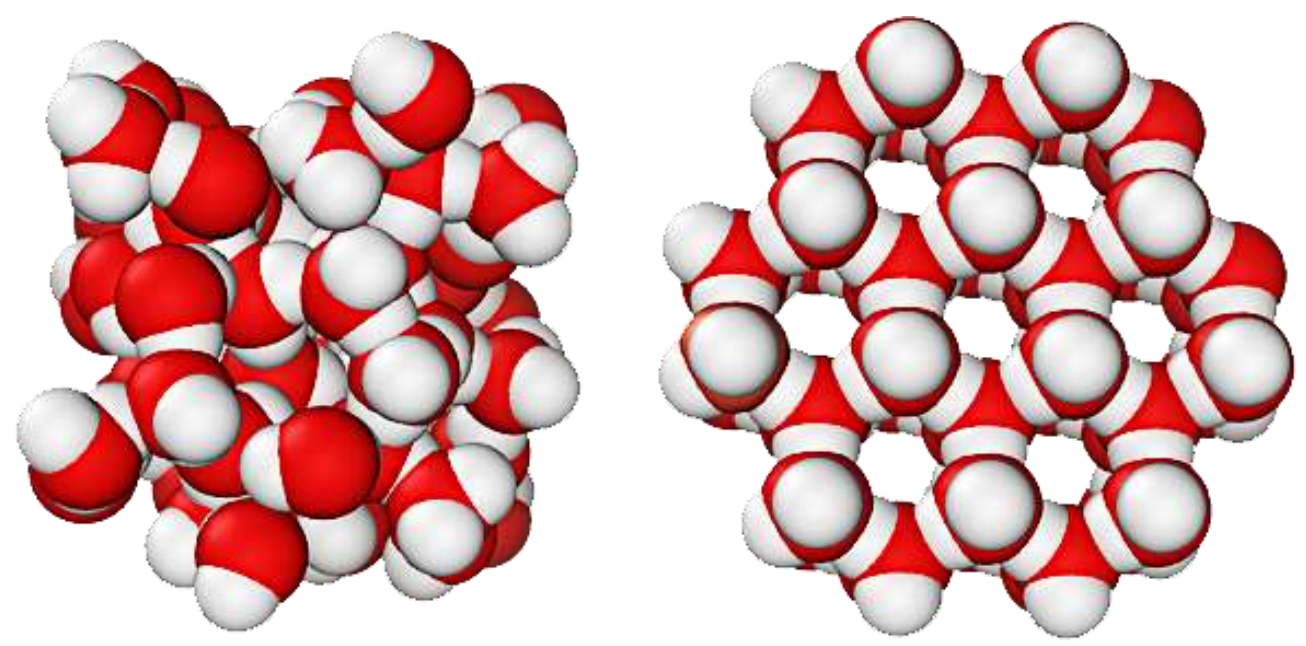

Figura 20-21. 3D modeli i ujit në gjendje të lëngshme dhe akulli (Burimi): P99am, 2010. E licensuar nga Creative Commons Attribution ShareAlike 3.0 Unported

Hibridizimi shkon përtej bashkimit të funksioneve, realisht me hibridizim tentohet që t'iu përgjigjemi tri shqetësimeve kryesore të shoqërisë dhe kohës aktuale:

1. Mungesa e tokës dhe vlera e sajë e lartë, kërkesa për sipërfaqe të tokës me qëllim ndërtimi dhe profiti duke kontribuar në zhvillimin rajonit, komunitetit apo shtetit si dhe kërkesa për dendësi më të madhe urbane.

2. Kërkesa për diçka specifike, duke u angazhuar arkitektët në programe jo të thjeshta ndërtimi, duke tentuar për maksimalizim fleksibiliteti.

3. Sipërfaqet e lira, toka dhe kostoja e ndërtimit me qasje klasike të menagjimit, shpenzimet për infrastrukturën e komunitetit, mirëmbajtja e ndërtesave të veçanta ka detyruar shumë institucione qeveritare dhe private për të gjetur mënyra të reja të ndërtimit dhe të vetë financimit apo koncesionit publiko privat, siç është rasti i garazhës publike tek QKUK. 
Trajtat dhe format programore si këto dukuri i detyrojnë shumë subjekte të heqin dorë nga disa elemente të tyre të individualitetit. Pak, kthim nga prapa në kohë, do të vërejmë se ndërtesat ishin reperë apo monumente të njohura të qytetit, aty takoheshim. Më kujtohet në rini, caktojshim takime tek: Shtëpia e Mallrave, Rektorati, Hoteli Grand, Komiteti, Planika etj. Ndërsa tani ndërtesat polifunksionale janë duke u shkrirë në siluetën e qytetit së bashku në anonimitetin e qetë. Andaj, ndërtesat hibride janë duke krijuar mundësinë e të pasurit qytet brenda qytetit, më atribute të dendësisë të lartë urbane duke shfrytëzuar apo konsumuar më pak hapësirë. Çfarë nënkuptohet më hibridizim në lëmit tjera të shkencave natyrore. Në kimi, hibride ose hibridizimi quhet koncepti i lidhjes së orbitaleve atomike në orbitale hibride të reja, me energji dhe trajta të ndryshme, të përshtatshme për lidhjen e elektroneve për të formuar lidhje kimike, teoria e lidhjeve valente. Në figurën si më poshtë përshkruhet hibridizimi me këto lidhje. Për një karbon me trajtë tetraedrike (p.sh., metani $\mathrm{CH} 4$ ) nevojitën 4 orbitale me simetri të saktë, të lidhura me 4 atome hidrogjeni (Bajçinovci, 2017).

Komponimi i karbonit është $1 s^{2} 2 s^{2} 2 p^{2}$ apo më saktë si më poshtë:

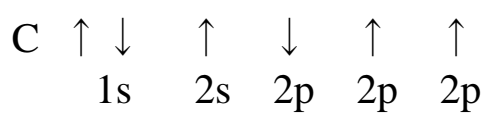

Figura 22. Hibridizimi orbital, katër orbitalet SP3

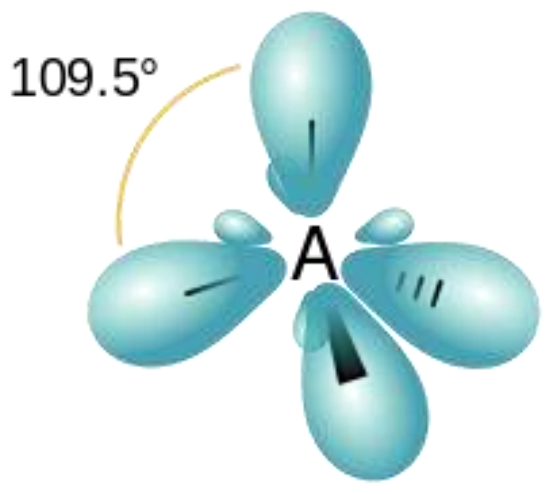

(Burimi): Ifmelero, 2011. E licensuar nga Creative Commons Attribution ShareAlike 3.0 Unported

Në mekanikën kuantike, një orbitale atomike është një funksion matematikor që përshkruan sjelljen valore e një elektroni ose e një çifti të elektroneve në një atom. Ky funksion mund të përdoret për të llogaritur probabilitetin e gjetjes së ndonjë elektroni në një atom në çdo pikë të veçantë rreth bërthamës.

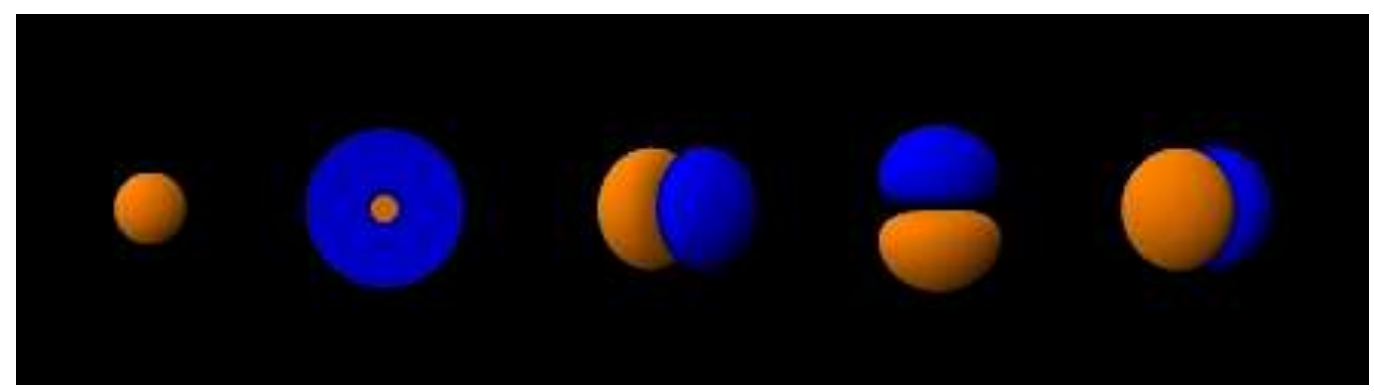

Nga e majta në të dhjathtë forma e pesë orbitaleve: $1 \mathrm{~s}, 2 \mathrm{~s}, 2 \mathrm{p}_{\mathbf{x}}, 2 \mathrm{p}_{\mathbf{y}}$ dhe $2 \mathrm{p}_{\mathbf{z}} .2 \mathrm{p}_{\mathbf{x}}, 2 \mathrm{p}_{\mathbf{y}}$ dhe $2 p_{z}$ në të vërtetë janë suborbitale, nëntipe të orbitales $2 p$. Orbitalet luajnë një rol të rëndësishëm në mënyrën se si atomet lidhjen me njëri tjetrin.

Figura 23. Neon orbitals

(Burimi): Kurzon, Dmacks, Mortadelo2005, 2006. E licensuar Public Domain 


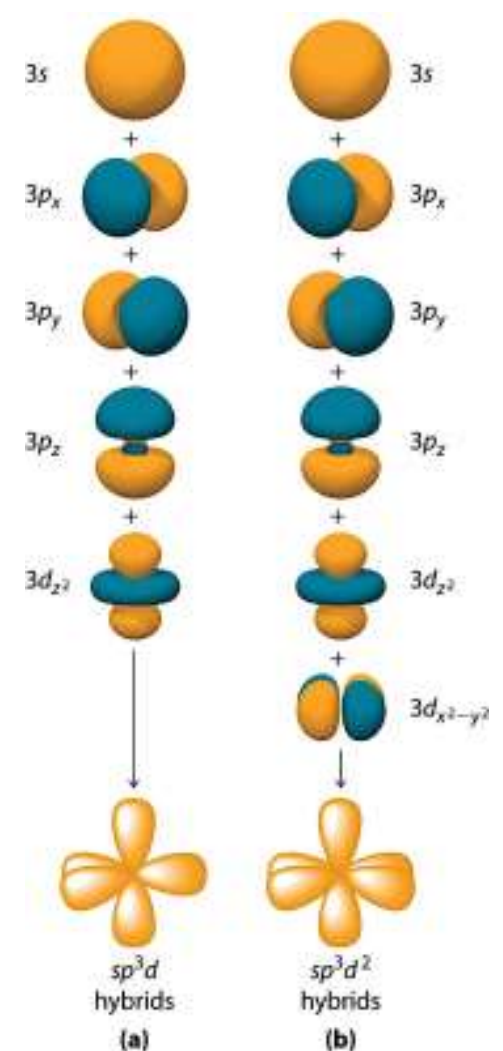

Figura 24. Orbitalet hibride

(Burimi): Averill, A.B. \& Eldredge, P. 2012. Principles of General Chemistry
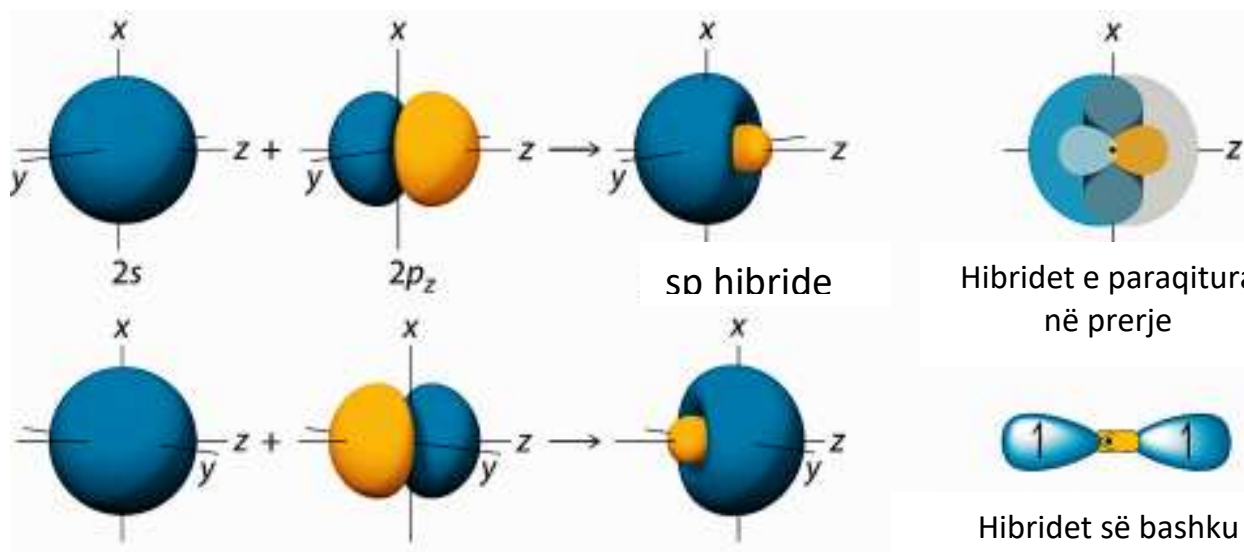

Hibridet e paraqitura në prerje

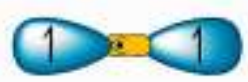

Hibridet së bashku të paraqitura

Figura 25. Formimi i sp orbitaleve hibride

(Burimi): Averill, A.B; Eldredge, P. 2012. Principles of General Chemistry 


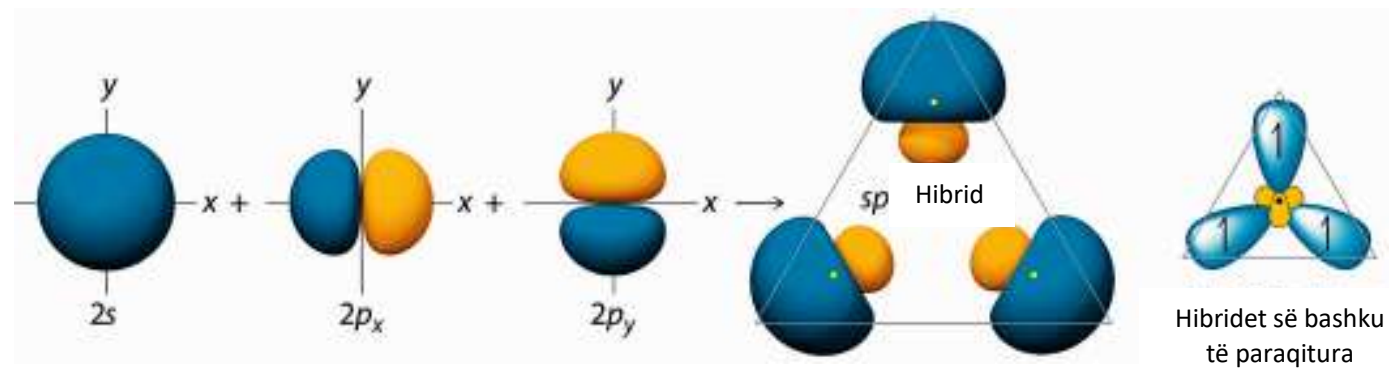

Figura 26. Formimi i $\mathrm{sp}^{2}$ orbitaleve hibride

(Burimi): Averill, A.B; Eldredge, P. 2012. Principles of General Chemistry

Ka një diferencë të dallueshmenë mes të përdorimit të miks apo bashkimit të ndërtesave dhe ndërtesave hibride, mirpo ekziston edhe dallimi esencial në mes të arritjes së lartë të dhe të ulët të hibridizimit të ndërtesave. Respektivisht ndërtesa të larta me përdorim të funksioneve të bashkuara dhe ndërtesave të ulta me funksioneve të bashkuara. Të dy rastet kanë pro dhe kontra arsye dhe atribute projektuese, mirpo të dy rastet e cekura artikulojnë dy mënyrat shrytëzimit të sipëfaqes dhe hapësirës. Në këtë kontekst bashkimi i funksioneve apo miksi i koncepteve në një ndërtesë nuk është i njëjtë sikur më parë, dhe sfidave të cilat na presin në të ardhmën. Ndërtesat hibride kanë të bëjnë me zgjidhje apo së paku ofrojnë zgjidhje më kërkesa të tilla si mungesa e tokës, densiteti i lartë dhe urbanizimi dinamik. Me që e ardhmja është afër, qysh në minutin e ardhshëm, ne, arkitektët, duhet të shikojmë nga e ardhmja me sfida bashkëkohore duke projektuar në të mirë të komunitetit, shoqërisë më të gjërë, dhe kujdesit permanent për mjedisin. $(\text { Ekstrakt })^{11}$

Andaj, në kontekst të së kaluarës, përkufizimi i hapësirave hibride nuk janë një risi, këtë e argumenton edhe Rem Koolhas në librin e 70-tave "Delirious New York". Libri atëherë u konsiderua si një utopi. Zhvillimi intensiv i ndërtesave hibride filloi duke u përjetuar në shekullin e 20, kur koncepti i zhvillimit të qyteteve kërkontë lidhje funksionale nga më të ndryshme, jo vetem në nivel qyteti por edhe në nivel ndërtesash dhe integrim të plote shërbimesh.

"Ju duhet të përpiqeni për përzierje apo bashkim e të gjitha funksioneve të jetës urbane në një projekt, dhe për të krijuar një hapësirë urbane" (Steven Holl, 2009)

Nga të gjitha që u thanë si më sipër, mund të konkludojmë se ndërtesat hibride apo ndërtesat multifunksionale ofrojnë një zgjidhje bashkëkohore fundamentale në raport me kërkesat e tregut dhe profitit, profiti, si motor gjenerues i zhvillimit shoqëror dhe $\mathrm{i}$ përmirsimit të kushtëve të jetesës. Sot, jemi dëshmitar së vetëm në Kosovë kemi kërkesa për këto lloje të ndertesave, arsyeja? Arsyeja është e thjeshtë, kemi ardhë në at stad të zhvillimit ku tregu dhe kërkesat janë në shtuarje e sipër për këto lloje të ndërtesave. Natyrisht, që mund të elaborojmë shumë më gjatë për arsyet kardinale, thelbsore arkitektonike dhe urbane për këtë fenomen, mirpo, mjafton të themi se ka kërkesa për tu investuar financiarisht, dhe kaq! (Bajçinovci, 2017).

11 Byrd,B. 2014. Hybrid Buildings. 
Në këtë drejtim, konsideroj se për të filluar procesin e projektimit për ndërtesat hibride, së pari duhet veçuar se çfarë kërkohet:

1. Nuk do të thotë se përherë duhet projektuar ndërtesa të reja. Vazhdimisht dhe gjithmonë duhet shiquar dhe inkurajuar rivitalizimin e ndërtesave apo blloqeve urbane së pari, kur për këtë të ketë mundësi dhe kur ja vlenë?

a. Këto ndërtesa paraqitën të shpeshta si interpolim në zonat e banuara

b. Të shpeshta si interpolim brenda blloqeve urbane

c. Si trajta pasazhi për këmbësorë

d. Si ndërtesa të vjetra, të lanura ashtu me kohë

e. Si ndërtesa të vjetra, të lanura ashtu në mungesë fondesh

f. Si ndërtesa të vjetra, të lanura ashtu në kontekste gjygjësore

2. Duhet kërkuar zgjidhje dhe harmoni simbiotike në mes mjedisit, lokacionit;

3. Duhet inkurajuar ndërtesa me kohë të plotë të funksionimit;

4. Duhet kërkuar zgjidhje dhe harmoni simbiotike në mes hor. dhe vertikales;

5. Duhet inkurajuar ndërtesa me funksione dhe qëllime komplekse, të larmishme.

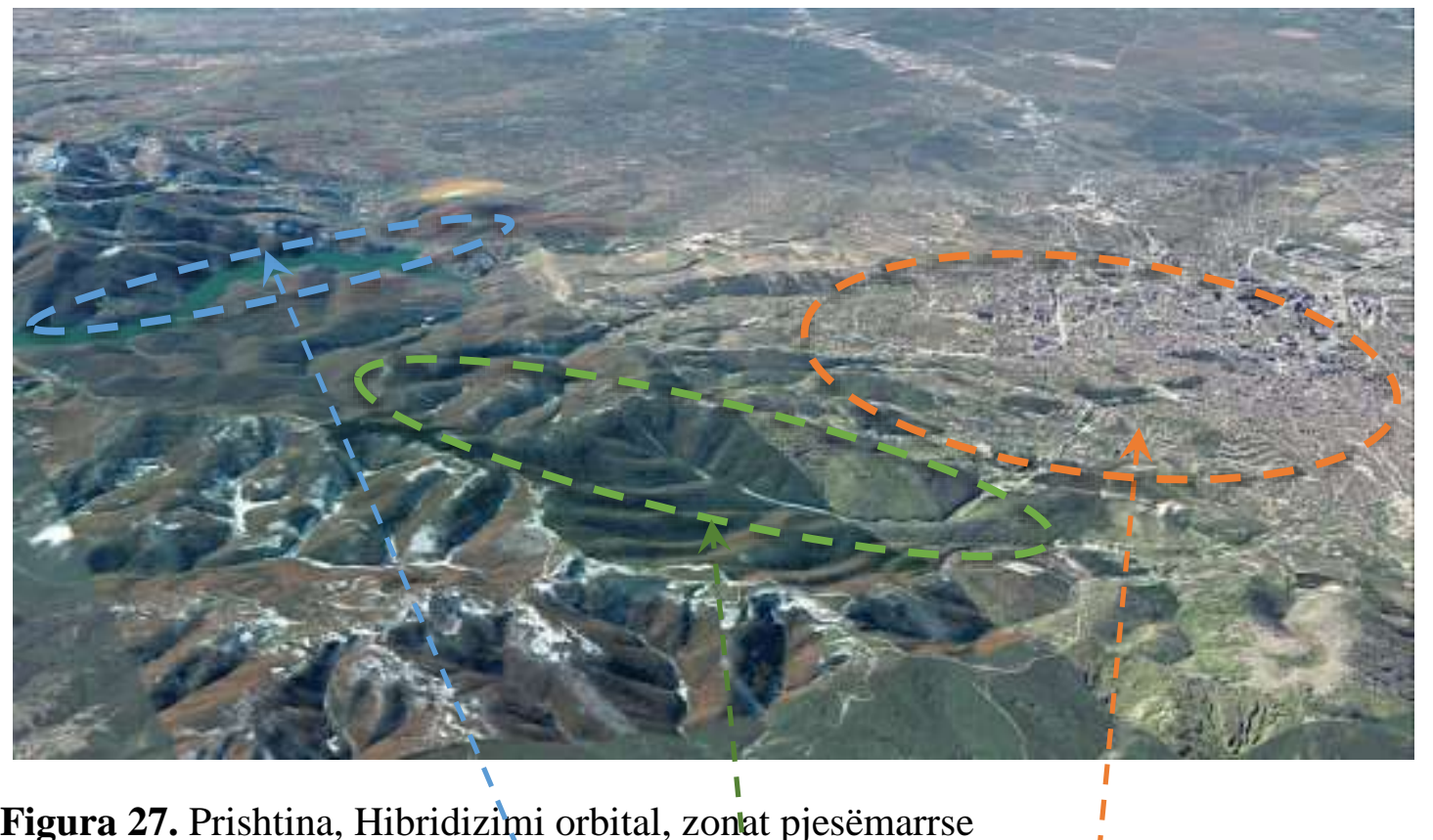

Figura 27. Prishtina, Hibridizilmi orbital, zonlat pjesëmarrse (Burimi): Imagery (02016 DigitalGlobe $\lambda_{\lambda}$ Google, CNES \Astrium, Map data @201'6 Google

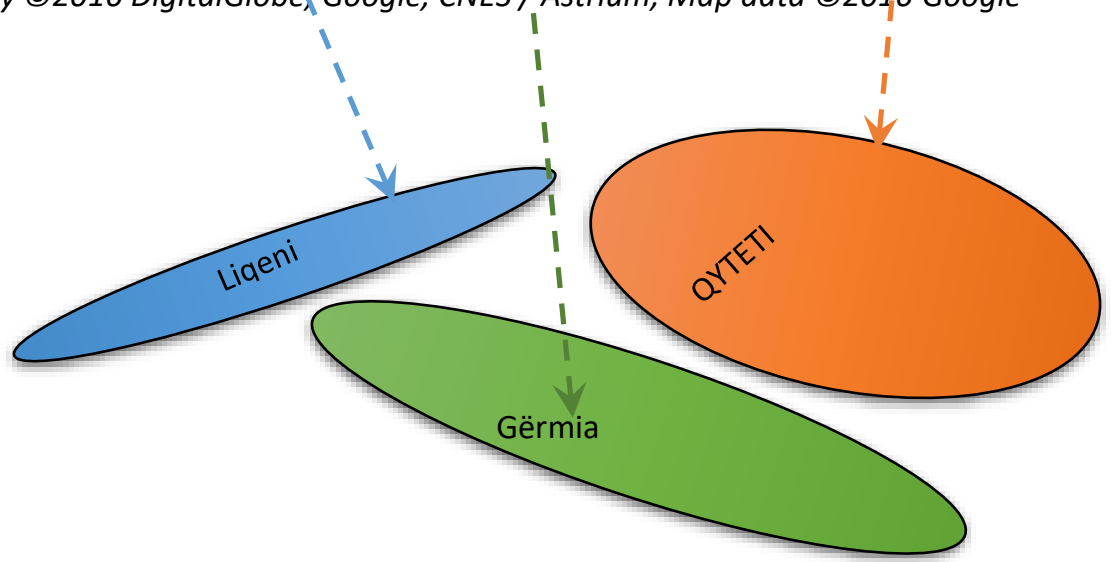




\subsubsection{Harmonia simbiotike, ndërtesa dhe mjedisi}

Shumë lëvizje ekologjike, arkitektë, konferenca, kongrese argumentuan në dobitë e së ruatjes së mjedisit, mirpo, duhet shkuar një hap para dhë të shofim ndërvarsitë e lidhjes apo harmonisë simbiotike në lidhje me mjedisin dhe ndërtesat, të cilat duhet të zhvillohen dhe të "jetojnë”. Së pari duhet zhvilluar nga pikëpamja e ruajtjes së mjedisit global, me ruajtjen e energjisë dhe burimeve natyrore si dhe duke bërë reduktimin e mbeturinave në të njëjtën kohë. Natyrisht kjo vlenë dhe i'u referohet jo vetëm ndërtesës dhe mjedisit të afertë, por edhe mjedisit lokal përreth. Andaj, qëllimi është që të ekzistojë një harmoni simbiotike me të dy mjediset: ati natyror dhe ai i ndërtuar. Esenca thelbësore do ishte për të siguruar urbanitëve një jetë apo kualitet jete më të mirë, më komfort, të pasur dhe të shëndetshëm, duke inkurajuar që secili pjesëmarrës në proces të marrë pjesë në procesin e ndërtimit, të marrë përgjegjësinë e kujdesit ndaj mjedisit (Bajçinovci, 2017).

Katër veçori të më poshtme korrespondojnë me tre objektivat themelore që duhet të realizohen për të arritur ekologjikisht harmonia simbiotike:

Në nivelin global, mbrojtja e mjedisit global me ndikim në:

1. Kursim të energjisë

2. Përdorimit më efektiv të burimeve natyrore

Në nivel lokal, harmonia me mjedisin rrethues

3. Adaptimi dhe harmonia me mjedisin lokal

Në nivelin banimor, një mjedis i shëndetshëm banimi dhe komfor

4. Shëndeti dhe komfori, të jemi dhe të ndihemi të sigurt

Kriteri i komforit nga aspekti i ndriçimit është një nga elementet më të rëndësishme dhe fondamentale, por njehërit është edhe një kërkesë themelore për perceptimin hapësirës. Drita, ose rrezet e diellit janë fenomen jetik për shëndetin dhe jetën e qenieve të gjalla. Ka hulumtime të panumërta shkencore që përmbledhin komforin e padiskutueshëm të kënaqshmërisë dhe komoditetit nga aspekti i ndriçimit, përndryshe paraqitën simptome të ndryshme të depresionit, sëmundjeve të ndryshme serioze, apati dhe në afat të gjatë çon në verbëri. Për të folur për arkitekturën, është për të folur për dritën, dhe mbi të gjitha për dritën natyrore. Kjo nuk është vetëm në lidhje me kapacitetin fizik që na lejon të shohim formën e brendshme dhe të jashtme të ndërtesës, por në ofrimin e arkitekturës me një komponentë kryesore të energjisë së nevojshme për ekzistencën e një dualiteti të integruar, të materies dhe energjisë, e cila nga dobia e thjeshtë gjeneron një sens estetik për përdoruesit. ${ }^{12}$

1. Historia e arkitekturës është histori e luftës për dritën, duke luftuar për një dritare. (LeCorbusier, 1989). ${ }^{13}$

2. Sipas mendimit tim, komfori i arkitekturës realizohet nga dy fjalë. E para prej tyre është "hapësira" e dyta është "drita". (Santiago Calatrava, CNN. 2006).

12 Ed. C, Gallo., M, Sala., A.M.M, Sayigh.(Eds).(1988). Architecture: Comfort and Energy. Elsevier.

13 Corbusier, L. (1989). Towards a new architecture. Oxford: Butterworth Architecture 


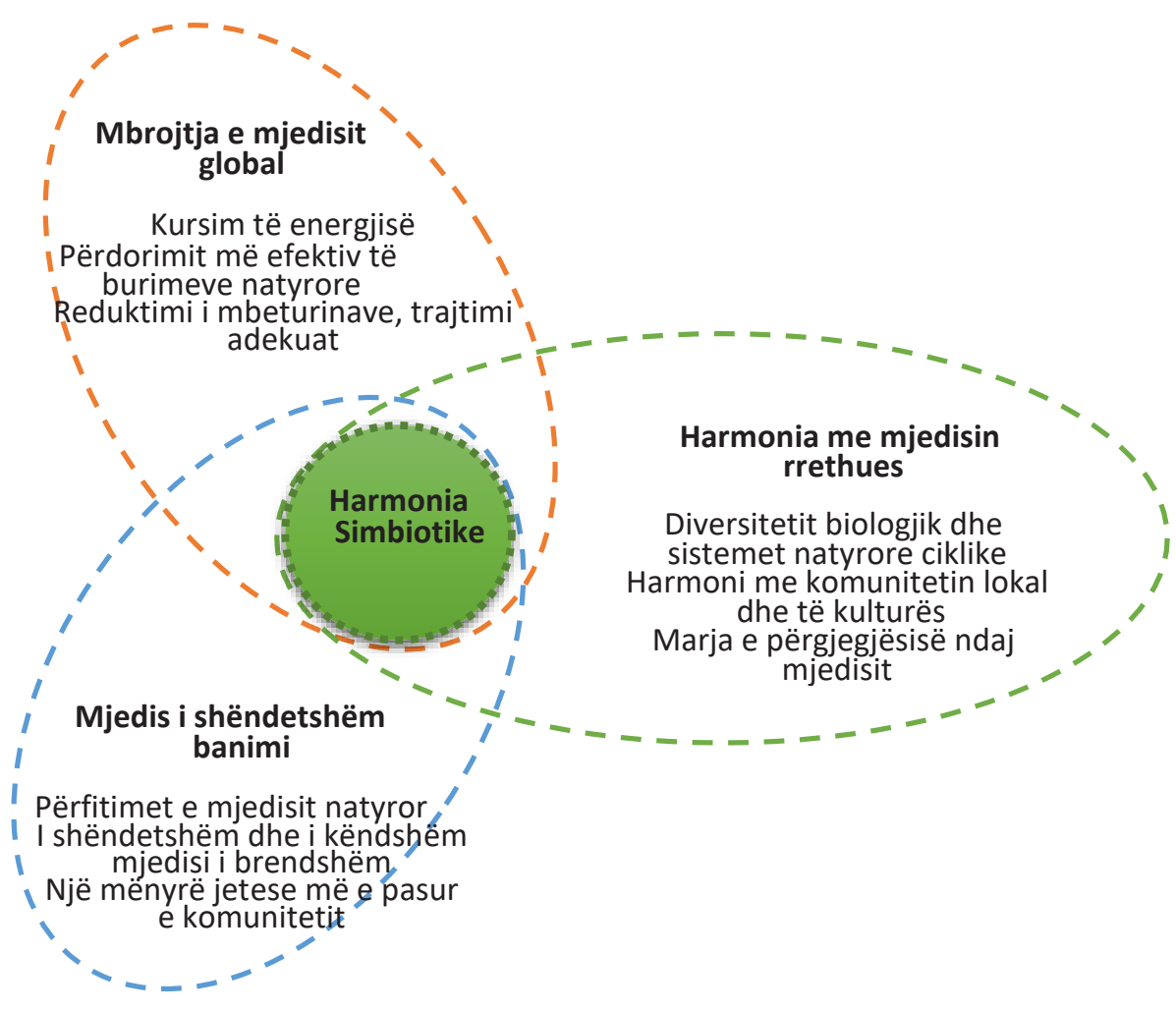

Figura 28. Struktura hibride organizative.

(Burimi): Bujar Bajçinovci. 2016.

1. Ndriçimi përmes dritareve është burimi kryesor për të siguruar nivelet e larta të dritës së nevojshme, për të mbështetur funksionimin e sistem circadian. ${ }^{14}$
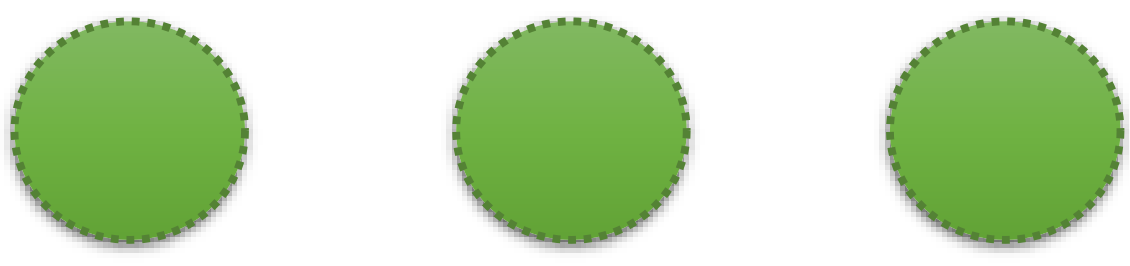

14 “Sistemi “circadian” na mban në sinkronizim me ditën 24-orëshe. Ora e brendshme e trupit tonë dërgon sinjale në shumë pjesë të ndryshme të trupit, si tretja, lirimi i hormoneve të caktuara, temperatura e trupit, dhe shumë më tepër! Një nga funksionet kryesore të orës së brendshme është të rregullojë fiziologjinë kur ndjehemi vigjilent dhe kur jemi gati për të fjetur. Shkencëtarët kanë parë për shembull, se kur njerëzit janë mbajtur të mbyllur pa rreze diellit ose pa orë për tu treguar atyre se çfarë është koha, ata zgjoheshin dhe bënin gjumë në një model afërsisht 24 orësh. Bimët e bëjnë këtë shumë interesant: vazhdojnë të lulëzojnë në mëngjes, edhe kur ato janë mbajtur në errësirë.“ Njeriu mbanë orën e brendshme në hap me ditën 24 orësh nëpërmjet rrezeve të diellit, ushqimit dhe aktiviteteve të tjera gjatë ditës, mirëpo, po ashtu edhe me errësirën gjatë natës. Ky proces i përshtatjes me orën e brendshme apo metabolizmit me sinjalet nga mjedisi vazhdon permanent. Me fjalë të tjera, ora e brendshme është disi fleksibile, kjo është arsyeja pse trupi ynë mund të mbajë me pauza gjatë ditës apo luhatjeve të lehta sezonale. Kjo është edhe arsyeja pse ne kur udhëtojmë nëpër zonat kohore trupi ynë përfundimisht do të hyjë në sinkronizim me kohën lokale." (Ekstrakt): http://sleepfoundation.org/ sleep-news/sleep-and-the-circadian-system. 


\subsubsection{Ndërtesat me kohë të plotë të funksionimit}

Vazhdimisht duhet kërkuar zgjidhje në hibridizimin e ndërtesave, konceptualisht në vëmendje të "orarit të plotë të punës" së ndërtesave. Kombinimi i më shumë se dy funksioneve, mund të rezultojë me efikasitet dhe rentabilitet të plotë të ndërtesave hibride (Bajçinovci, 2017).
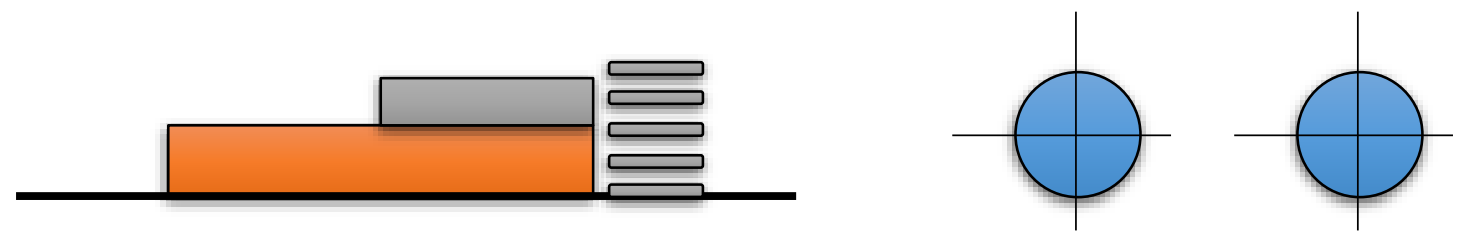

Figura 29. Garazha, 24 orë pune, gjatë 24 orëve (Burimi): Bujar Bajçinovci. 2016.
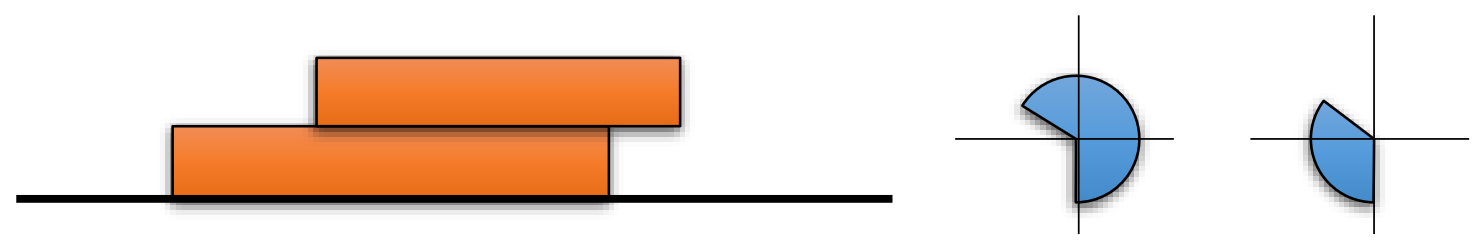

Figura 30. Qendra tregtare 12 orë pune, gjatë 24 orëve (Burimi): Bujar Bajçinovci. 2016.

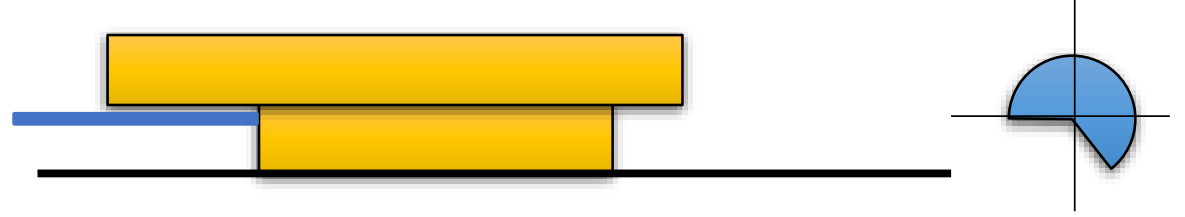

Figura 31. Administrata 8 orë pune, gjatë 24 orëve (Burimi): Bujar Bajçinovci. 2016.
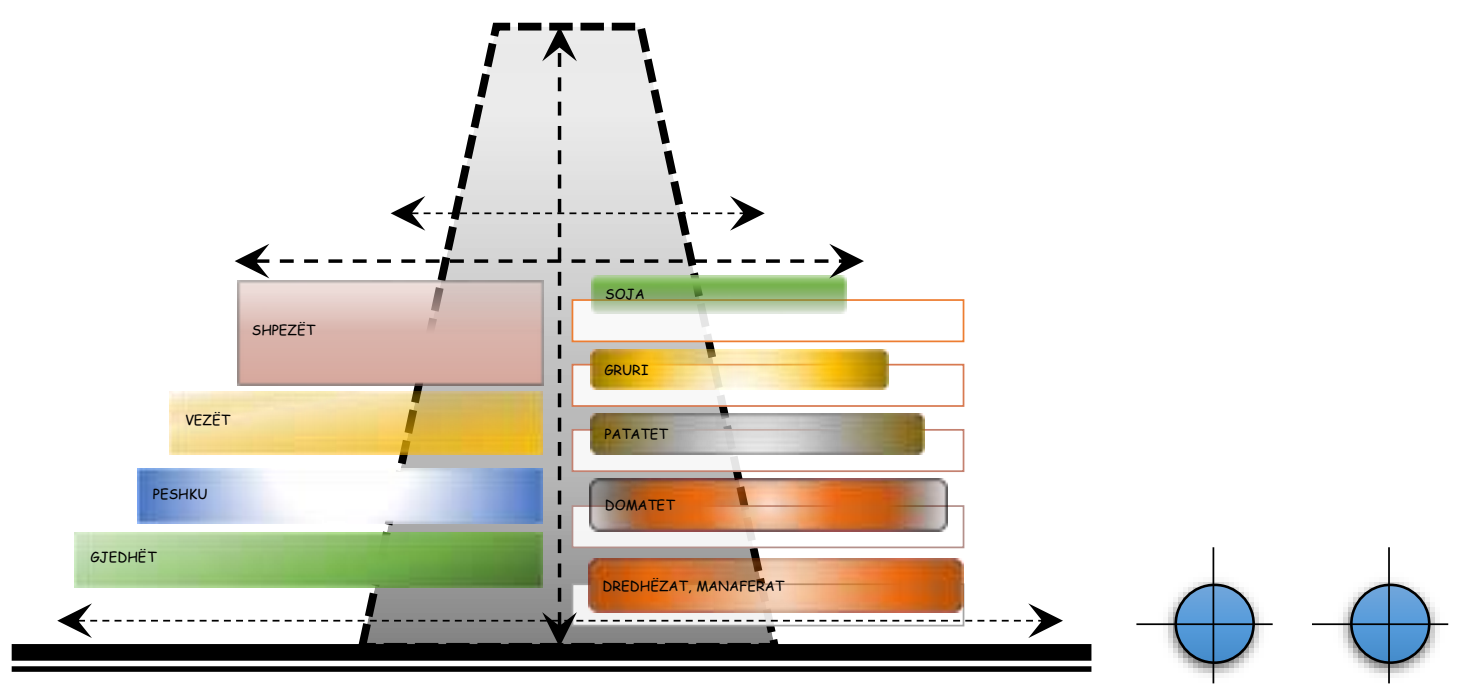

Figura 32. Ferma vertikale 24 orë pune, 7 ditë në javë (Burimi): Bujar Bajçinovci. 2017. 


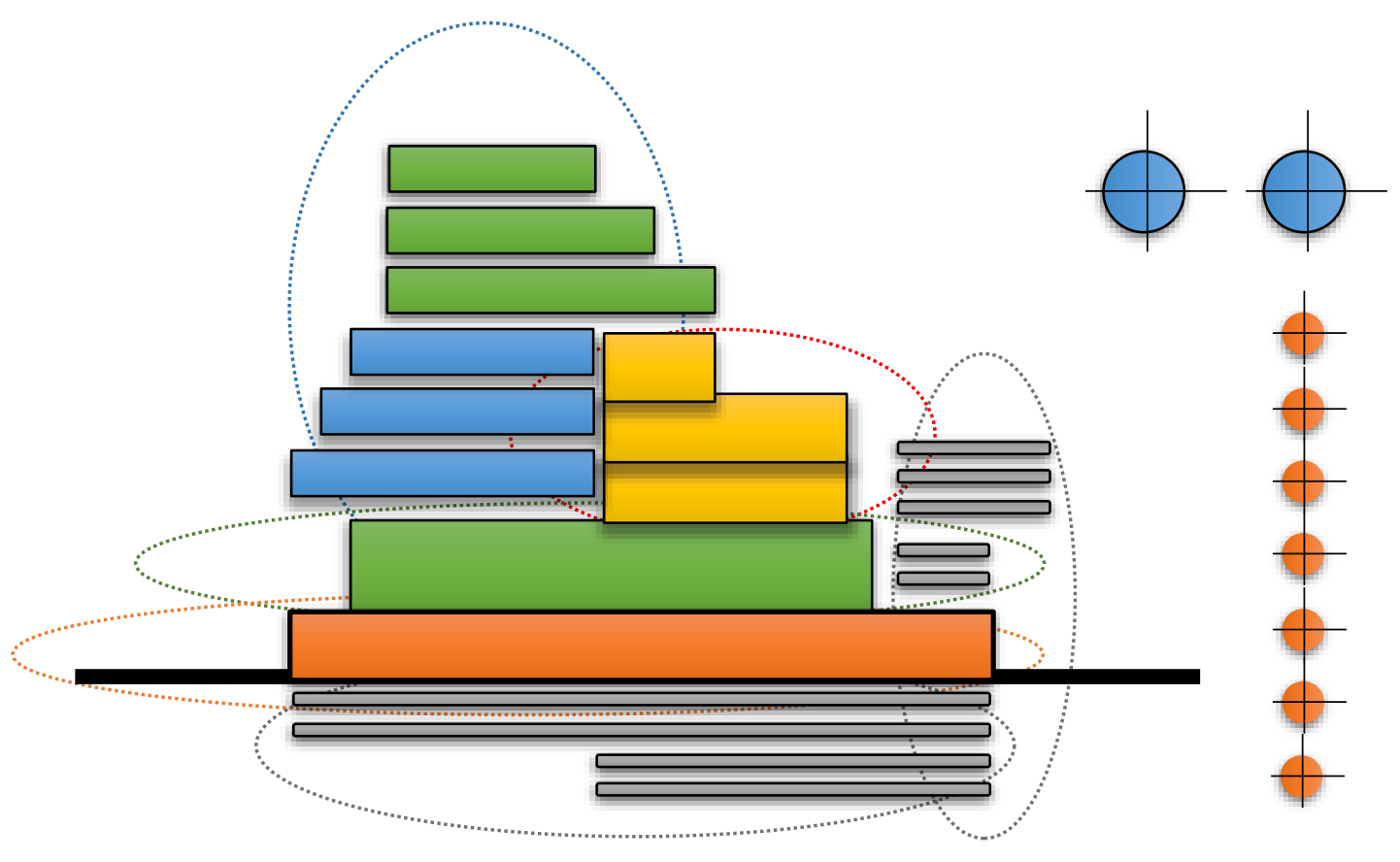

Figura 33. Ndërtesa hibride multifunksionale 24/7 ditë në javë. (Burimi): Bujar Bajçinovci. 2016.
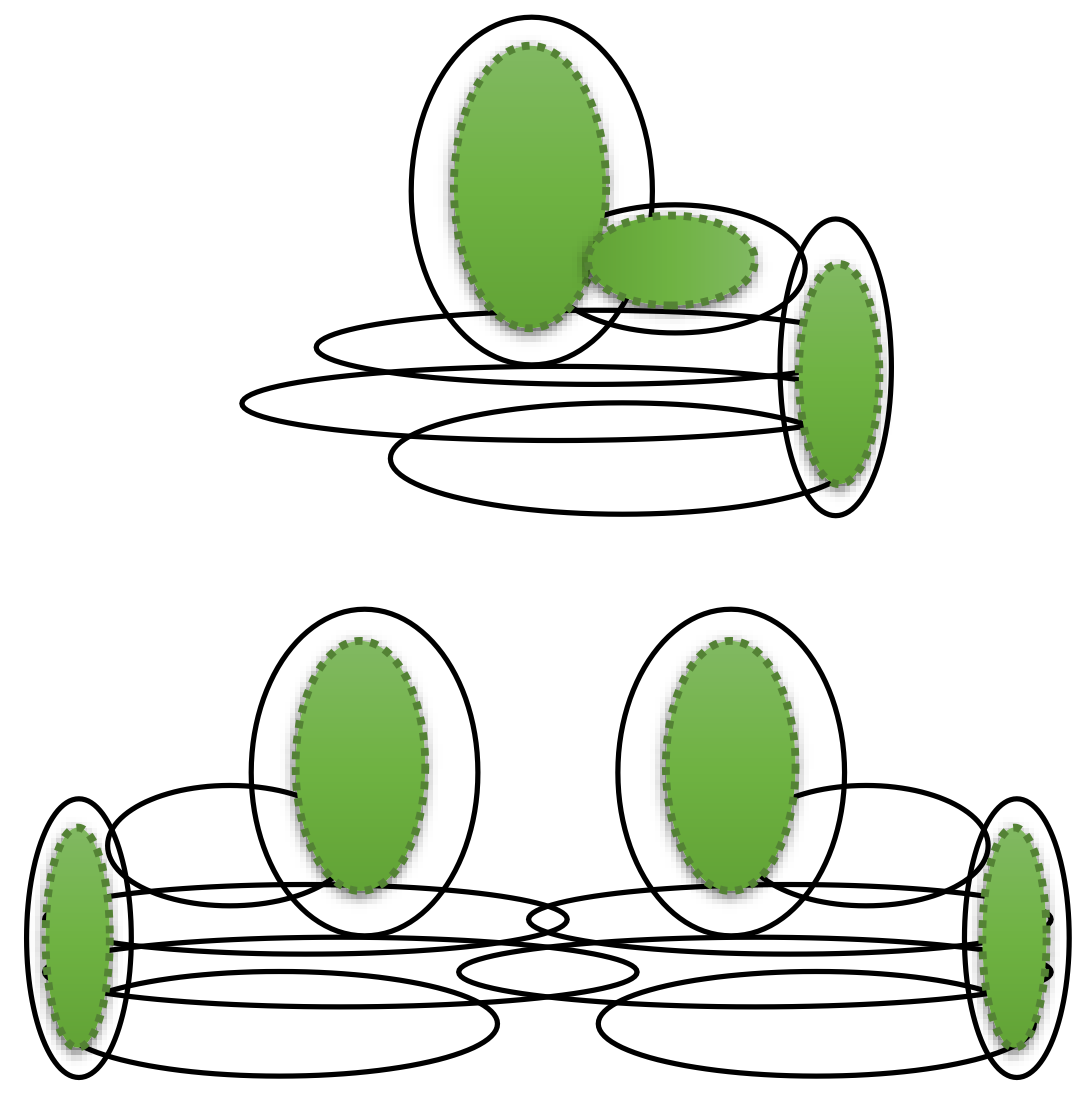

Figura 34. Struktura komplekse. Ndërtesa hibride multifunksionale 24/7 në javë. (Burimi): Bujar Bajçinovci. 2017. 


\subsubsection{Strukturat, simbiozë në vertikale dhe horizontale}

Trajta dhe proporcionet në ndërtesë duhet të janë të ndërlidhura në mënyrë të duhur në kompozicionin e zgjidhjes arkitektonike. Natyrisht, funksioni dhe trajta duhen shprehur qartë në pamjen vizuale të ndërtesës së synuar. Vazhdimisht duhet kërkuar që formësimi i realizuar arkitektonik të jetë rjedhojë e zgjidhjes funksionale arkitekonike. Funksioni, raporti i vertikales me horizontalen, formësimi kompozicional duhen të janë rezultat i një studimi dhe hulumtimi të mirëfilltë multiprofesional. Në figurat e më poshte do të shofim ndarjen dhe zonimin funksional në horizontale, të një ndërtese të synuar (Bajçinovci, 2017).

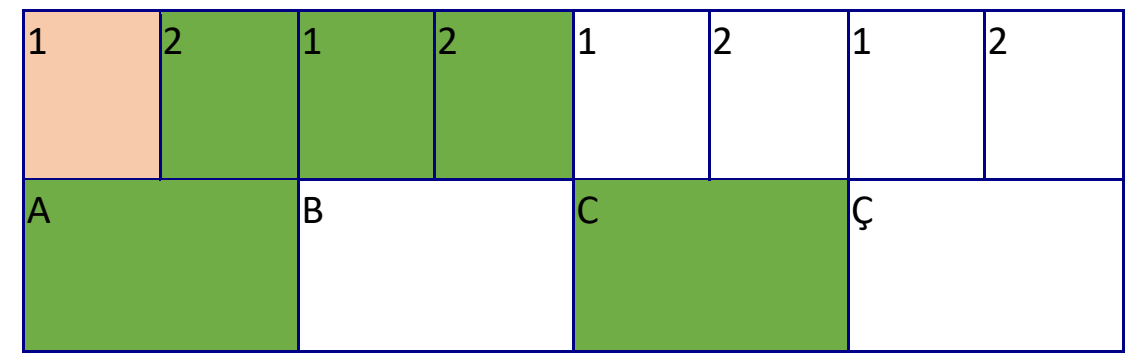

Figura 35. Zonat hibride multifunksionale. (Burimi): Bujar Bajçinovci. 2017.

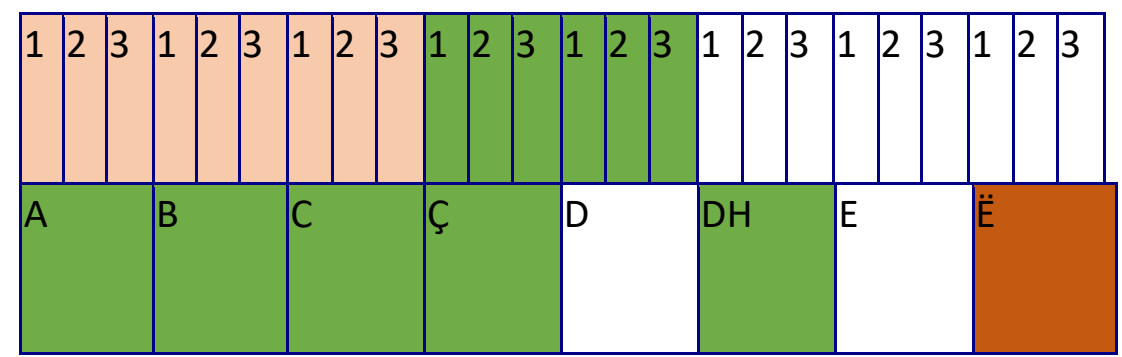

Figura 36. Zonat hibride multifunksionale.

(Burimi): Bujar Bajçinovci. 2017.

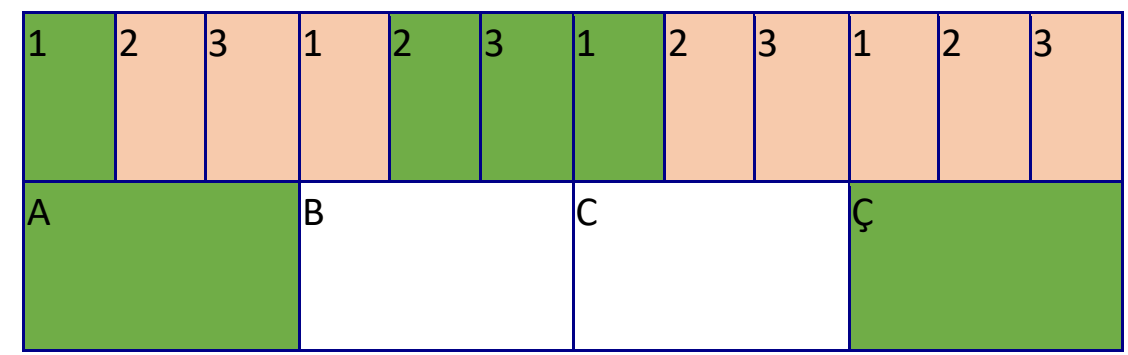

Figura 37. Zonat hibride multifunksionale.

(Burimi): Bujar Bajçinovci. 2017. 


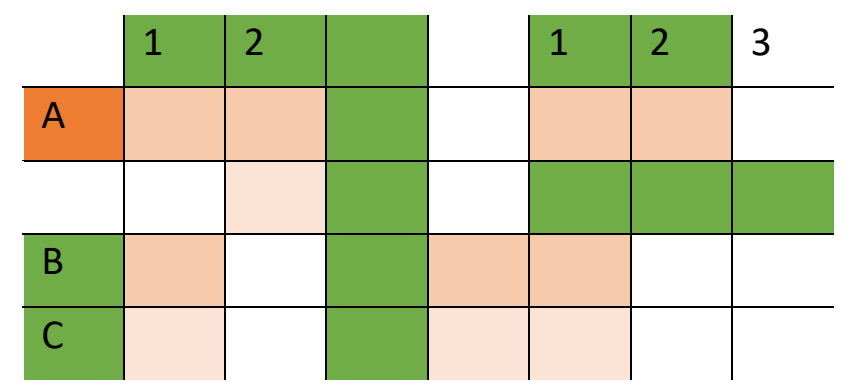

Figura 38. Variacionet. Zonat hibride multifunksionale.

(Burimi): Bujar Bajçinovci. 2017.

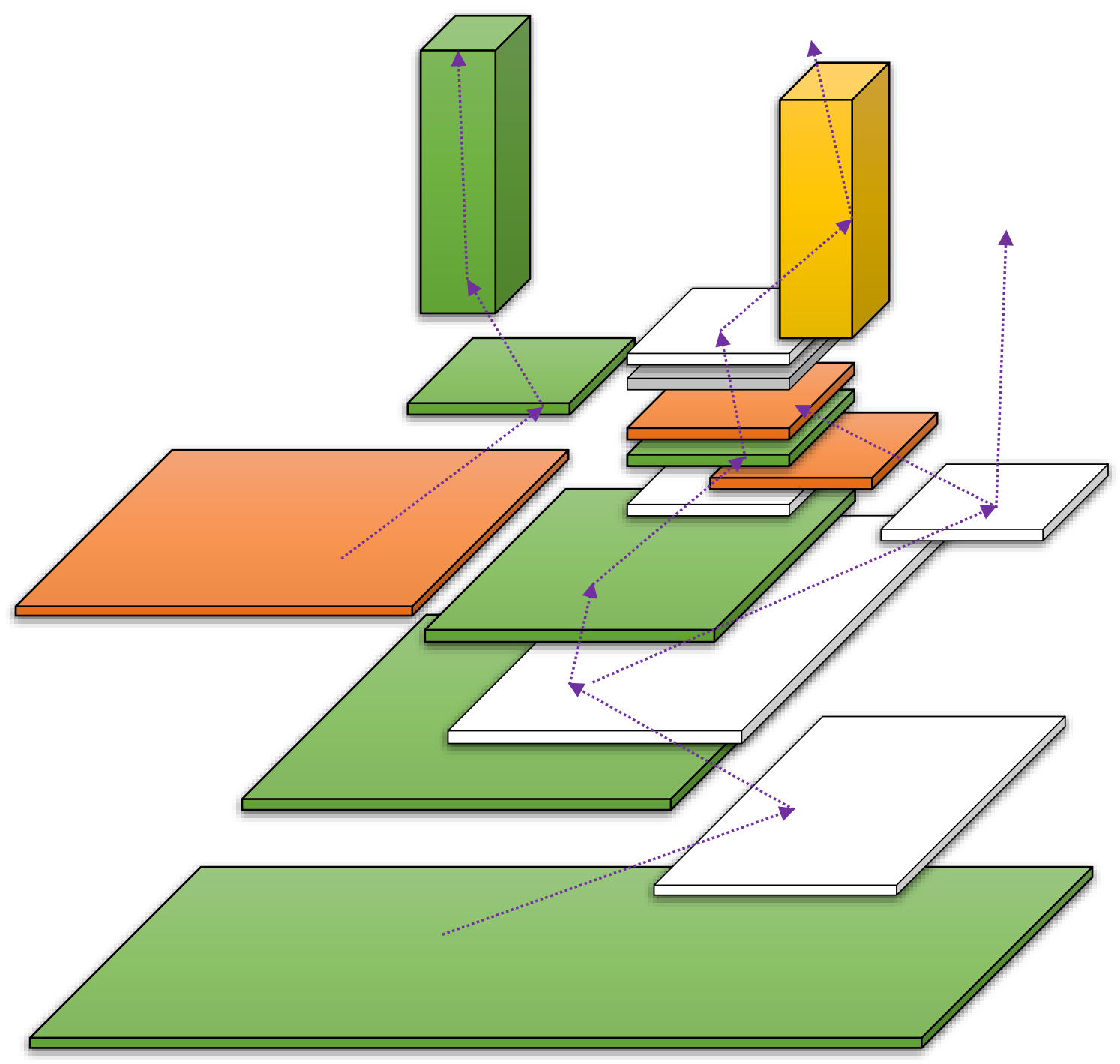

Figura 39. Dekomponimi i sipërfaqeve horizontale dhe vertikale e një tërësie komplekse hibride.

(Burimi): Bujar Bajçinovci. 2017. 


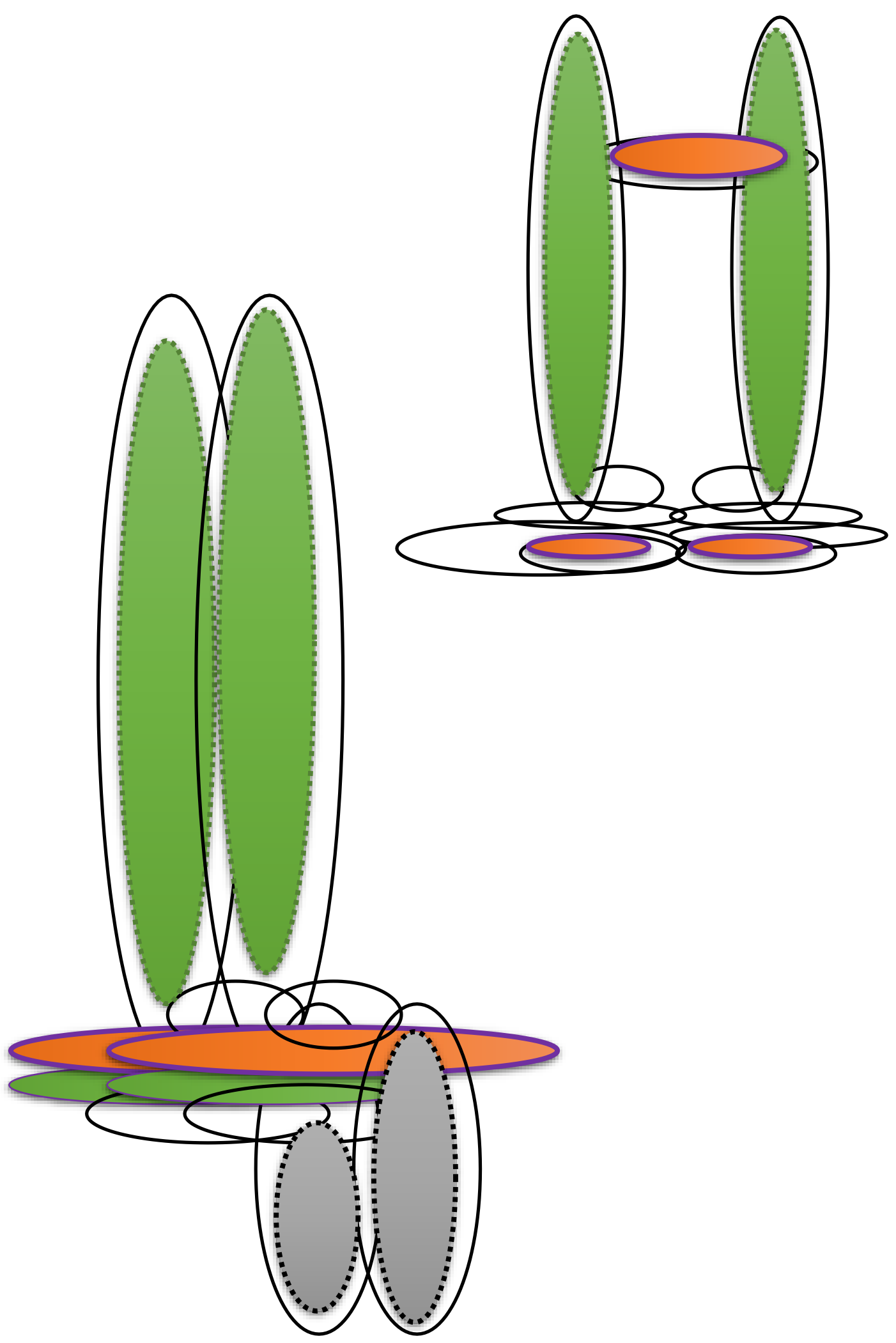

Figura 40. Variacionet. Zonat hibride multifunksionale. Dekomponimi i sipërfaqeve horizontale dhe vertikale e një tërësie

(Burimi): Bujar Bajçinovci. 2017. 


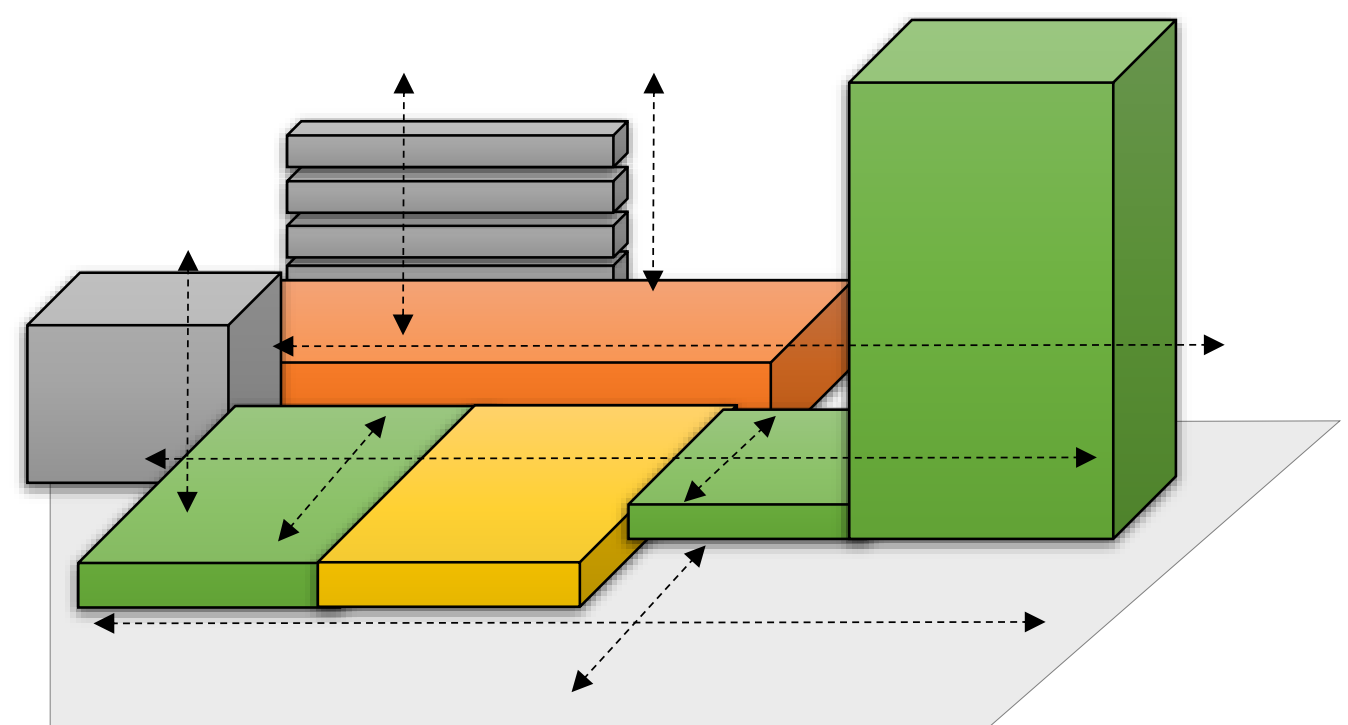

Figura 41. Dekomponimi i sipërfaqeve horizontale dhe vertikale e një tërësie (Burimi): Bujar Bajçinovci. 2017.

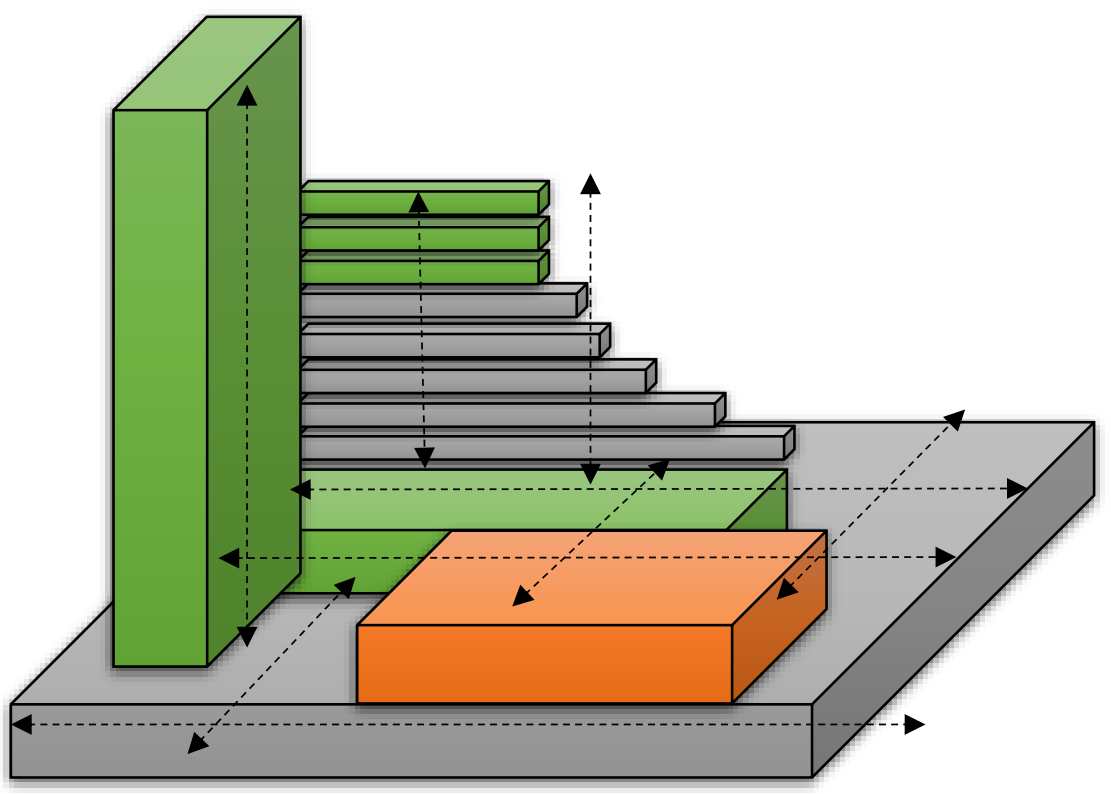

Figura 42. Dekomponimi i sipërfaqeve horizontale dhe vertikale e një tërësie (Burimi): Bujar Bajçinovci. 2017.

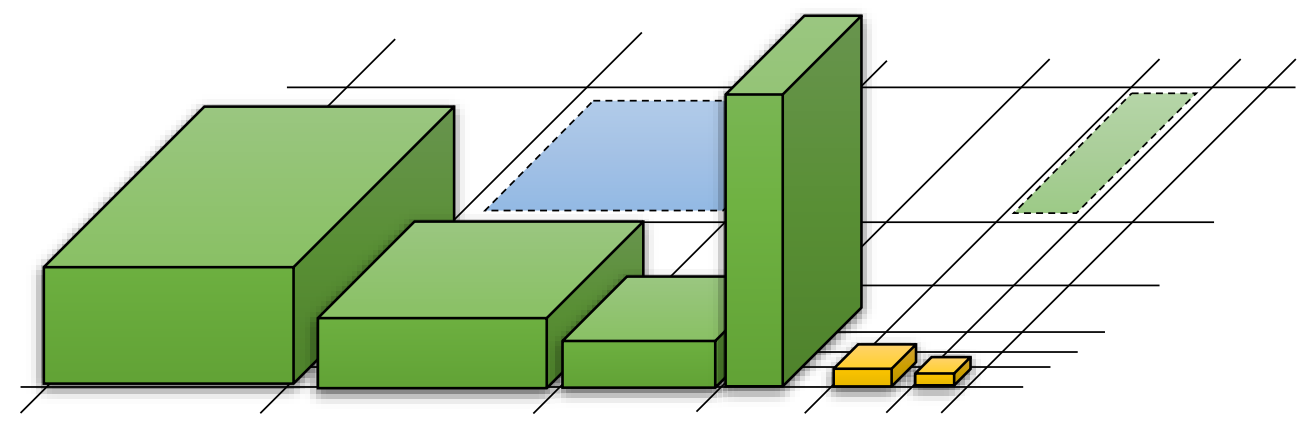

Figura 43. Variacionet. Zonat hibride multifunksionale. Dekomponimi i sipërfaqeve horizontale dhe vertikale e një tërësie (Burimi): Bujar Bajçinovci. 2017. 


\subsubsection{Ndërtesa hibride me funksione dhe qëllime komplekse, dinamike.}

Struktura fluide, dinamike, organike. Struktura me funksion dhe kontruksione hibride nga ekranet e kompjuterit në 3D filluan të ndërtohen, kush kishtë parashikuar që brenda disa dekada një hap kaq fundamental në arkitekturë do të rezultonete, më ndërtesa të cilat disi çvendosin mendësinë e parimeve gravitacionale apo ekzistencës gravitacionale? Konceptet arkitektonike arrinjë simbiozë dhe rezultojnë më një bashkim tërësor të funksioneve dhe elementeve të ndryshëm, duke sjellë paqartësi konstruktive në lidhje me stabilitetin e strukturave! Kjo shkrirje, kjo simbiozë dhe hibridizim gjeneron një nocion të ri të identitetit arkitektonik, karakteristika dhe veçori të ndryshme ekzistojnë në nivele të caktuara të cilat lidhen me njëra tjetrën, apo me hibridizimin e strukturave, formave dhe funksioneve, të cilat, si të mëvetshme e kanë origjinën diku tjetër (Bajçinovci, 2017).
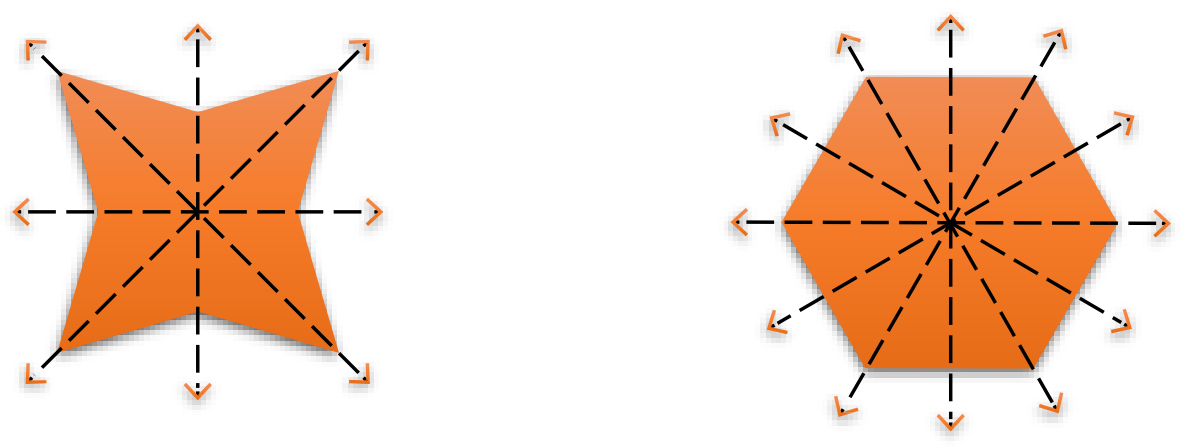

Figura 44. Variacionet, trajtat. Komponimi i sipërfaqeve horizontale të një tërësie. (Burimi): Bujar Bajçinovci. 2016.

Strukturat hibride nuk kanë një normë dhe një shkallë autentike të njohur, organizimi dhe kompozicioni i tyre është i drejtuar në koncepte multidimensionale, duke lejuar zgjerim funksionesh, duke mos u kufizuar në zgjërim apo shkurtim funksionësh. Dukuri, e cila rezulton me shkrirje funksionësh, strukturave, programeve të cilat derdhen në njëra tjetrën.

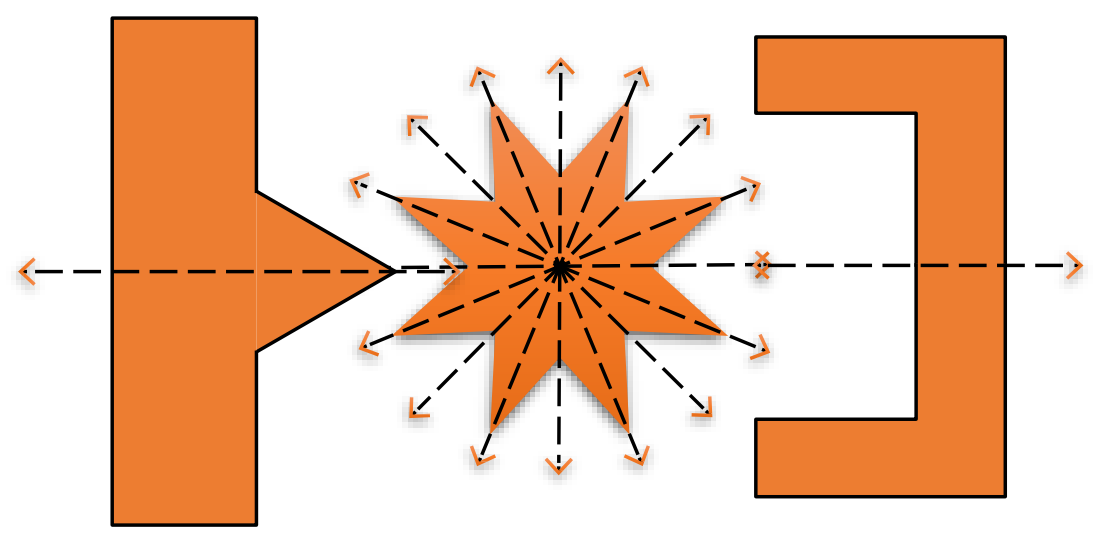

Figura 45. Variacionet, trajtat. Komponimi i sipërfaqeve horizontale të një tërësie. (Burimi): Bujar Bajçinovci. 2016. 


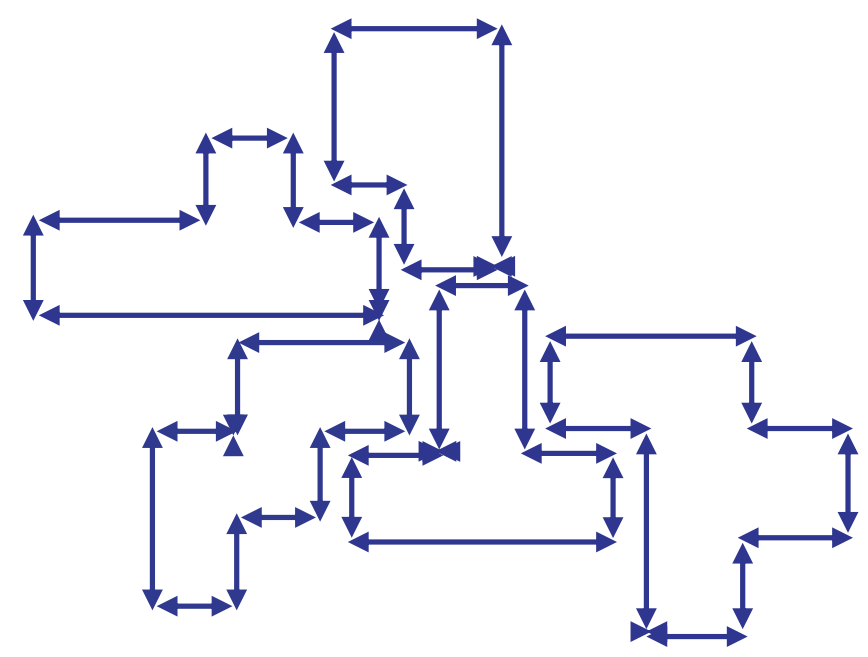

Figura 46. Variacionet, trajtat. Komponimi i sipërfaqeve horizontale të një tërësie. (Burimi): Bujar Bajçinovci. 2016.

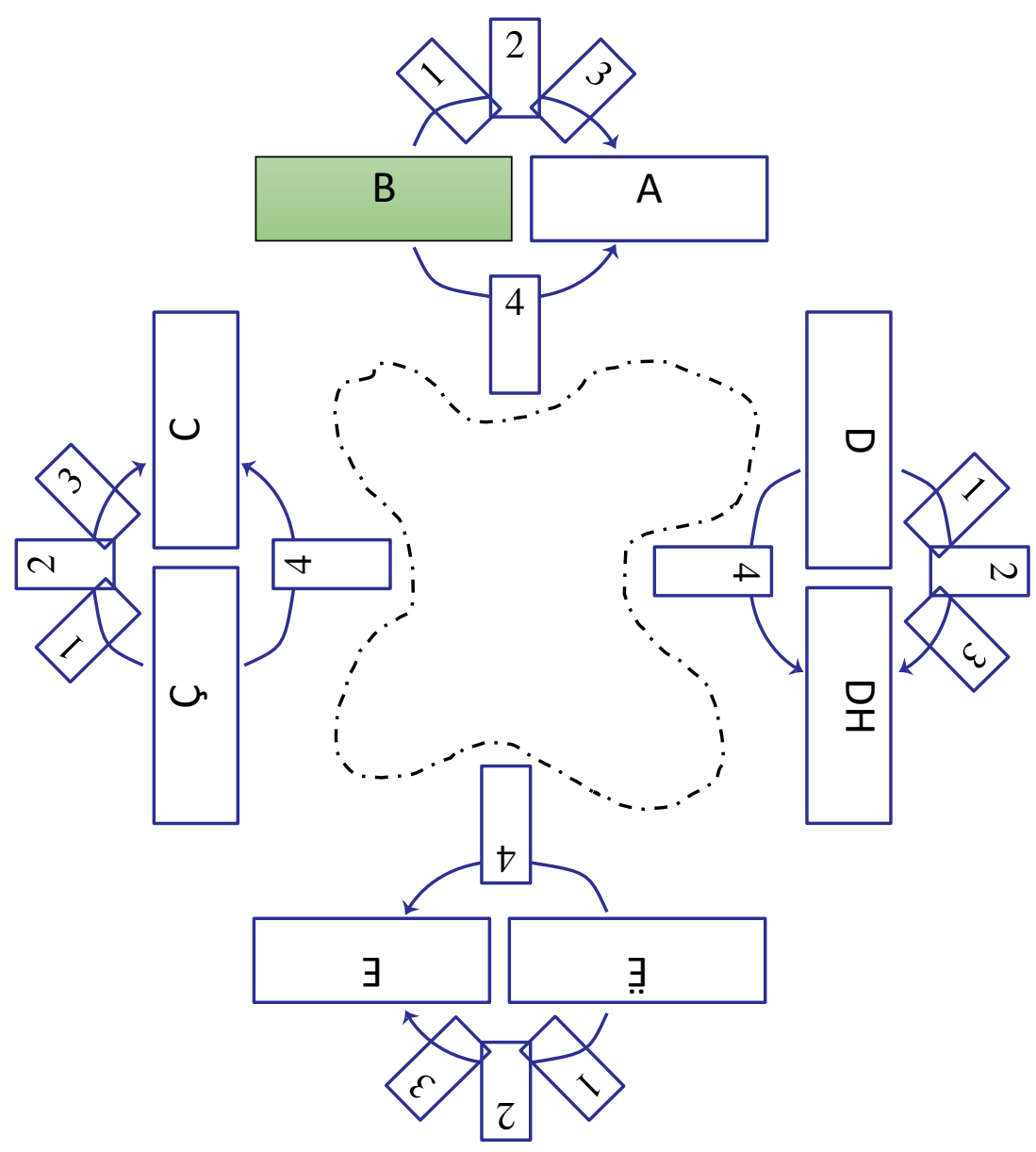

Figura 47. Variacionet, trajtat. Komponimi i sipërfaqeve horizontale të një tërësie. (Burimi): Bujar Bajçinovci. 2016. (Burimi): Bujar Bajçinovci. 2016. 


\subsubsection{Ndërtesa hibride - kompozicionet komplekse, adaptive dhe dinamike.}

Aktualisht, mund të argumentohet se ndërtesa hibride është realisht një "bllok urban" në vetvete, në të cilat hasim veprimtari të të kondensuara të cilat kontribuojnë në sferën publike të mjedisit, lagjes apo qytetit. Andaj ato paraqesin reperë apo pika interesi si nga aspekti vizual apo të ndonjë trajte me veçoritë apo atributet vertikale dhe horizontale. Si ndërtesë e tillë, hibride, ajo shtrihet në rrafshin horizontal dhe vertikal duke i lidhë urbanitët brenda dhe jashtë saj. Sot, vlerat, trendet e reja për qytetin, kërkojnë interpretime të reja të koncepteve arkitektonike. Arkitektura e ndërtesës hibride ripërcakton dhe shpreh simbiozë te re në mes arkitekturës dhe qytetit, në një mënyrë të veçantë. Në figurat si më poshtë, paraqitën mundësitë e kompozicioneve funksionale komplekse dhe dinamike. Dinamike, në kuptimin e fleksibilitetit ku zonat funksionale dhe elementet e strukturës mund të shtohen apo te hiqen sipas nevojes (Bajçinovci, 2017).
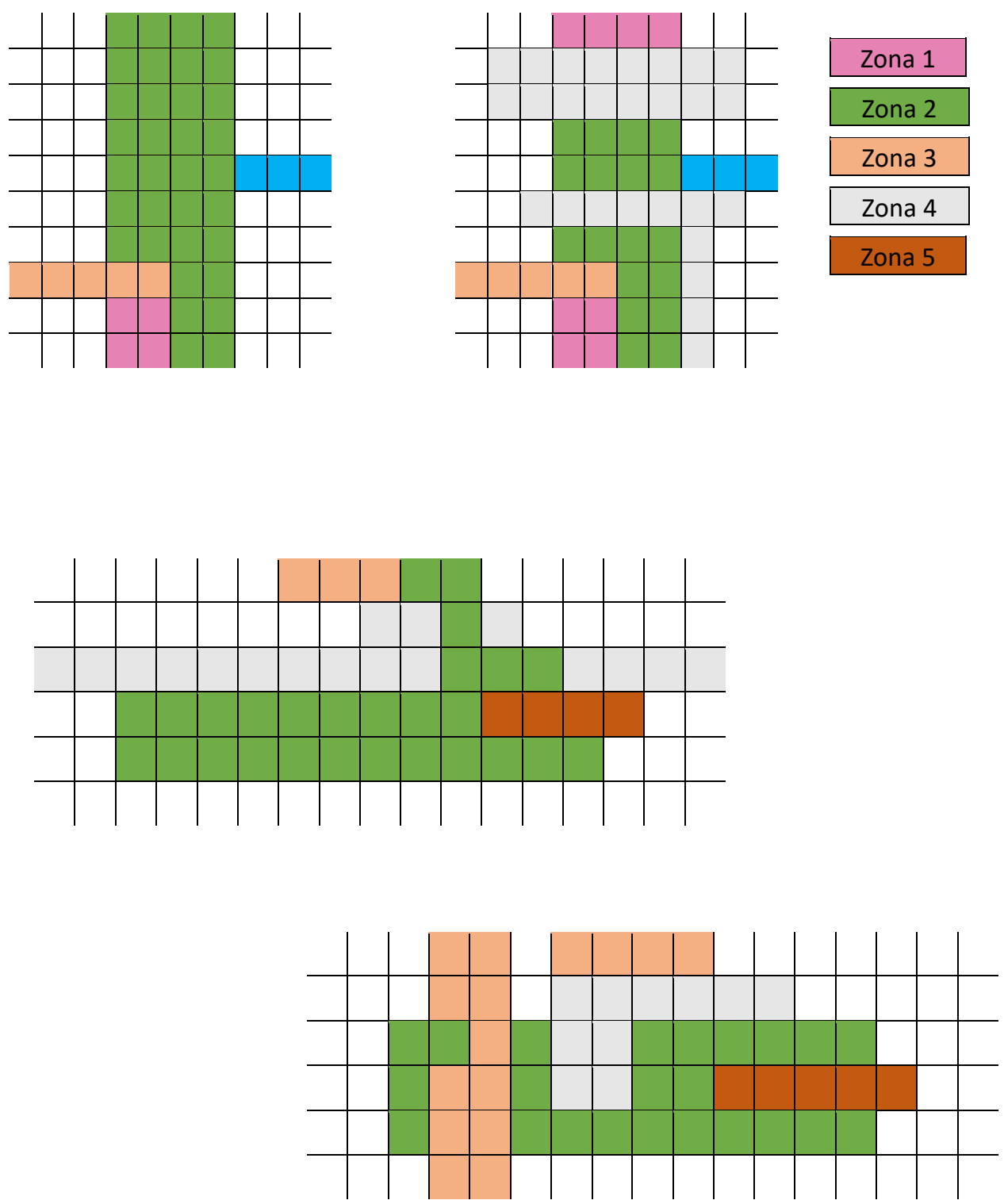

Figura 48. Variacionet, trajtat. Komponimi i sipërfaqeve horizontale. (Burimi): Bujar Bajçinovci. 2016. 

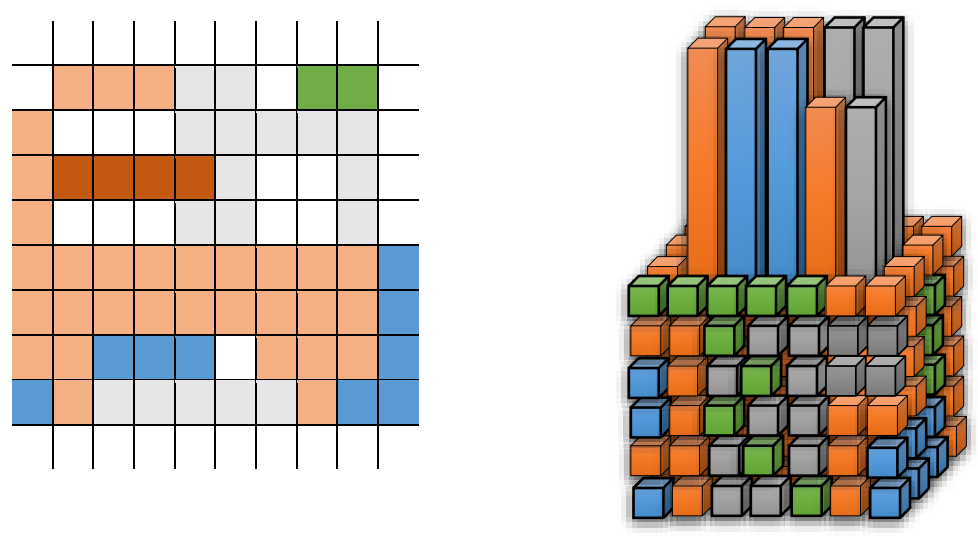

Figura 49. Komponimi i sipërfaqeve horizontale dhe vertikale e një tërësie në 3D. (Burimi): Bujar Bajçinovci. 2016.

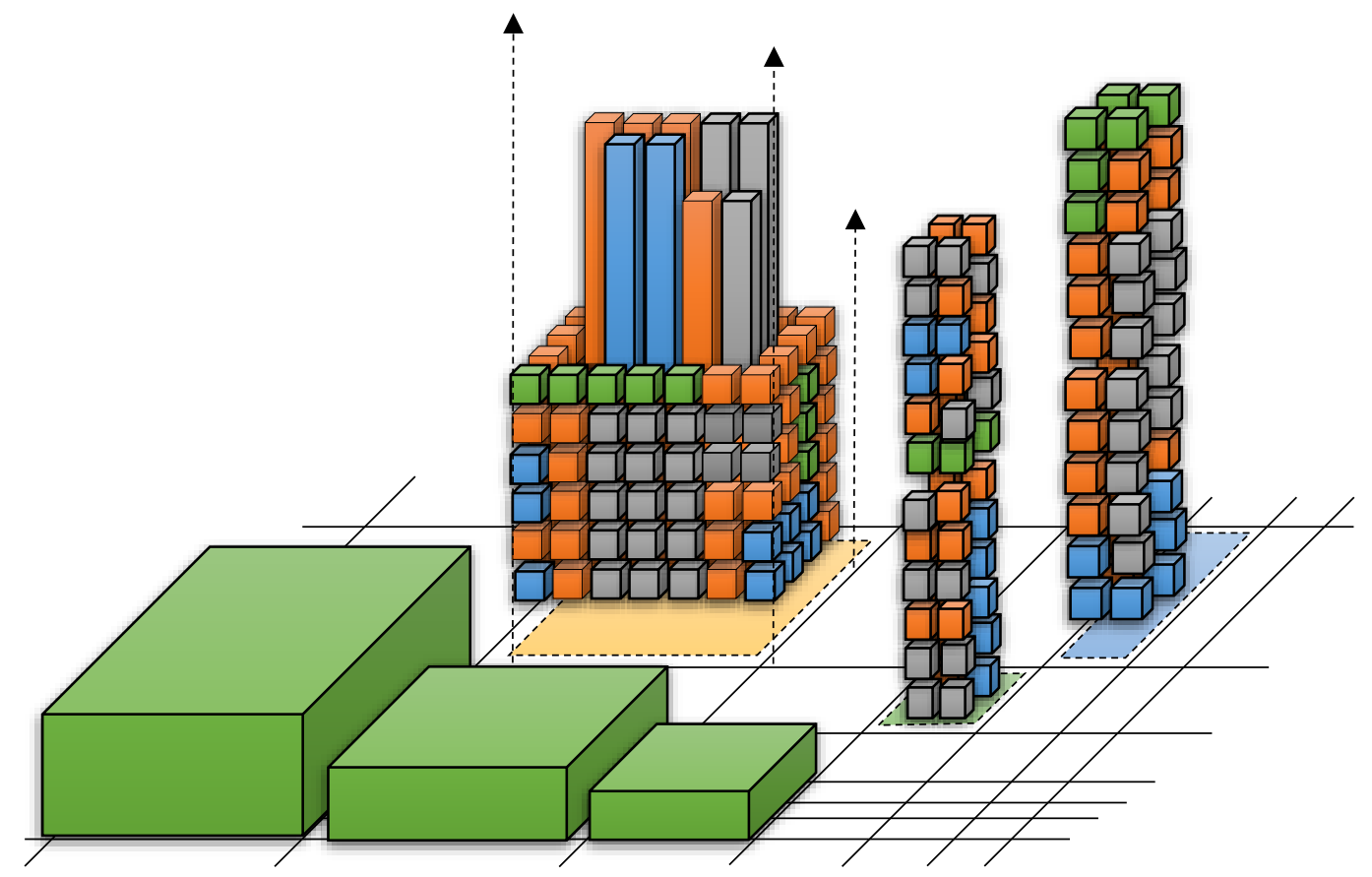

Figura 50. Komponimi i volumeneve në një tërësi hibride - 3D. (Burimi): Bujar Bajçinovci. 2016. 

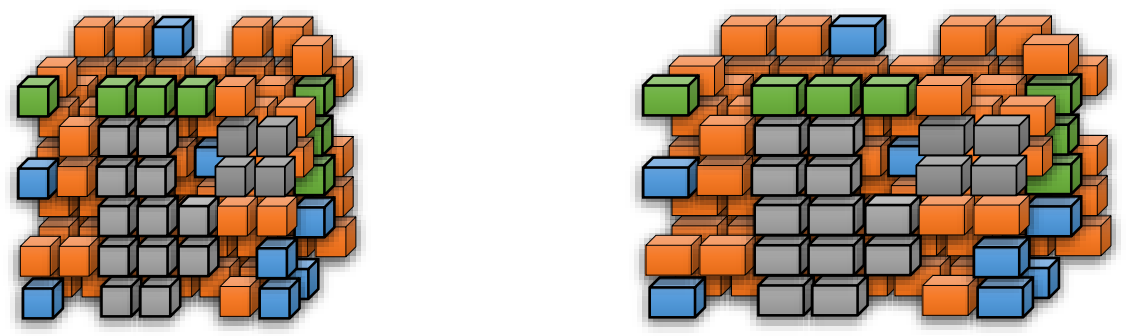

Figura 51. Komponimi i volumeneve në një tërësi hibride - 3D. (Burimi): Bujar Bajçinovci. 2016.
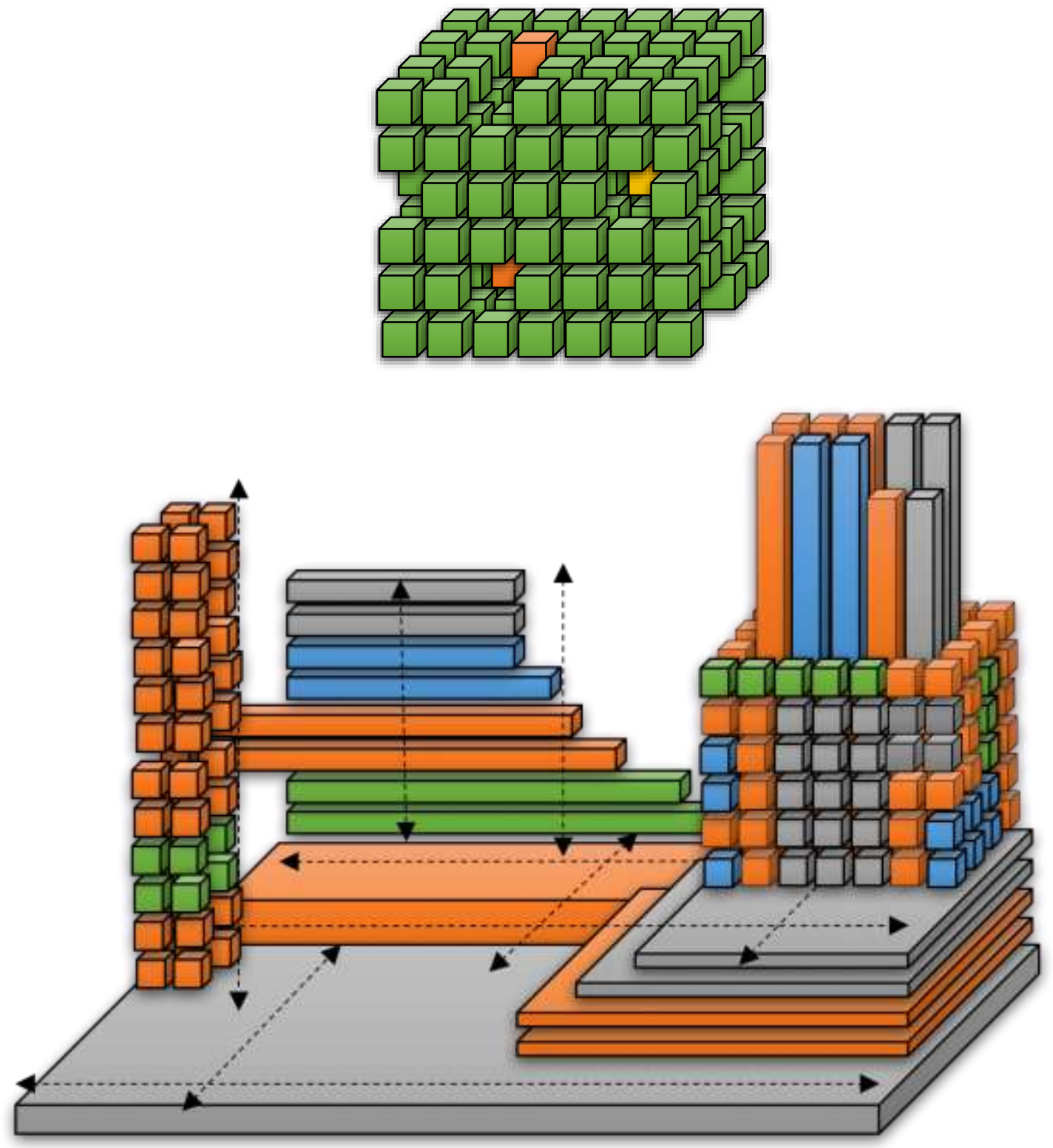

Figura 52. Komponimi i volumeneve në një tërësi hibride - 3D. (Burimi): Bujar Bajçinovci. 2016. 


\subsection{MATERIALET PËR SISTEMET KONSTRUKTIVE}

Përzgjedhja e materialeve për sistemin konstruktiv në parim kushtëzohet nga kërkesat funksionale teknologjike, ndikimi i emisioneve të ndryshme në elementet konstruktive (avujt, lagështia, acidet), nga rreziku i zjarrit në prodhim, mundësia e ndërtimit në atë lokacion, materiali për konstruksion është lehtë i disponueshëm, kostoja etj. Në përgjithësi për struktura të fermave dallojmë sisteme konstruktive të ndërtuara nga materialet:

1. Beton Arme

2. Çelikut

3. Drurit të Lameluar

\subsubsection{Strukturat konstruktive nga beton armea}

Ramët konstruktiv nga beton armea deri në një distancë prej 30.0 m', janë shumë ekonomikë. Mirëpo, mbi këto hapësira drite të sipërcituara këto lloj konsruksionesh fillojnë ta humbin rentabilitetin ekonomik për shkak të peshës. Në parim këto konstruksione punohen në vend, duke arritur kështu ngurtësinë e konstruksionit për pranim teknik. Aktualisht, në mënyrë që të bëhet kursimi në pahi për konstruksion, kohës së duhur për punim dhe arritjes së ngurtësisë së kërkuar, sot kjo tipologji e sistemit konstruktiv gjithnjë e më shpesh është duke u realizuar nga elementet e parafabrikuara, të beton armesë. Sipas trajtes së tyre të përgjithshme, ky lloj konstruksioni mund të realizohet si hallë e vetme, dy anijatshe, apo edhe tri anijatshe, që do të thotë se hallat mund të jenë fleksibile për nga formësimi arkitektonik (Bajçinovci, 2017).

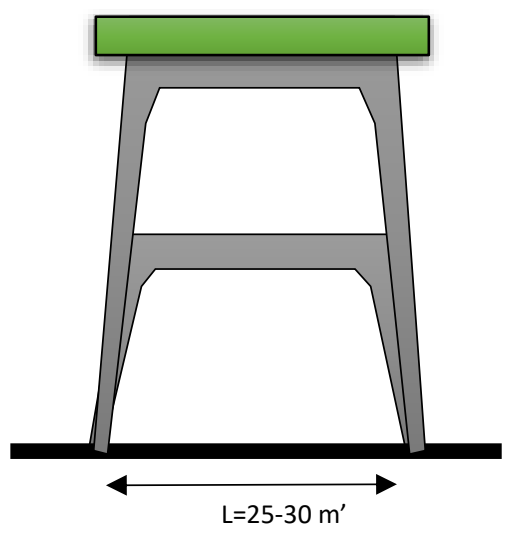

Figura 53. Struktura ram nga betonarmea (Burimi): Bujar Bajçinovci. 2017.

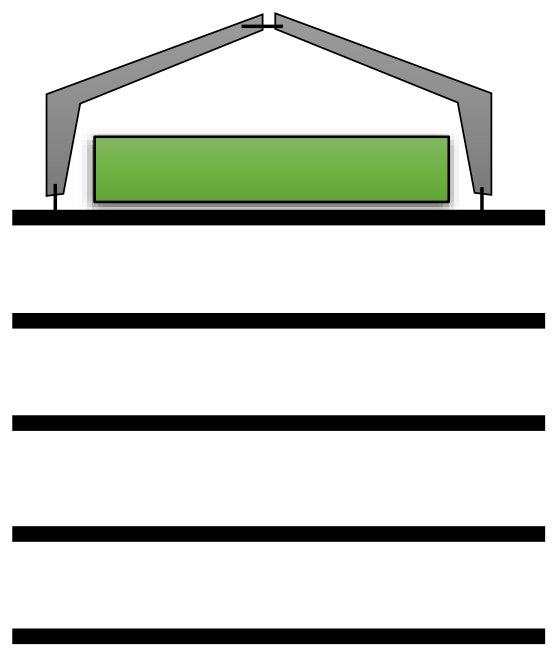




\subsubsection{Strukturat konstruktive nga çeliku}

Sistemi konstruktiv nga çeliku e gjenë përdorimin rentabil me distanca mbi 30.0 m', ku edhe janë sisteme shumë ekonomike. Në parim këto konstruksione punohen në uzinë, duke arritur kështu trajtën finale para liferimit të konstruksionit për pranim teknik. Po ashtu sipas trajtes së tyre të përgjithshme, ky lloj konstruksioni mund të realizohet si hallë e vetme, dy anijatshe, apo edhe tri anijatshe, që do të thotë se hallat mund të jenë fleksibile për nga formësimi arkitektonik. Pavarësisht nëse bëhet fjalë për një konstruksion të salduar, apo kapriatave në aspektin akademik duhet patjetër të dallojmë strukturën primare mbajtëse në një drejtim dhe atë sekondare në drejtimin tjetër, përmes së cilës vendoset struktura e kulmit apo struktura terciare (Bajçinovci, 2017).
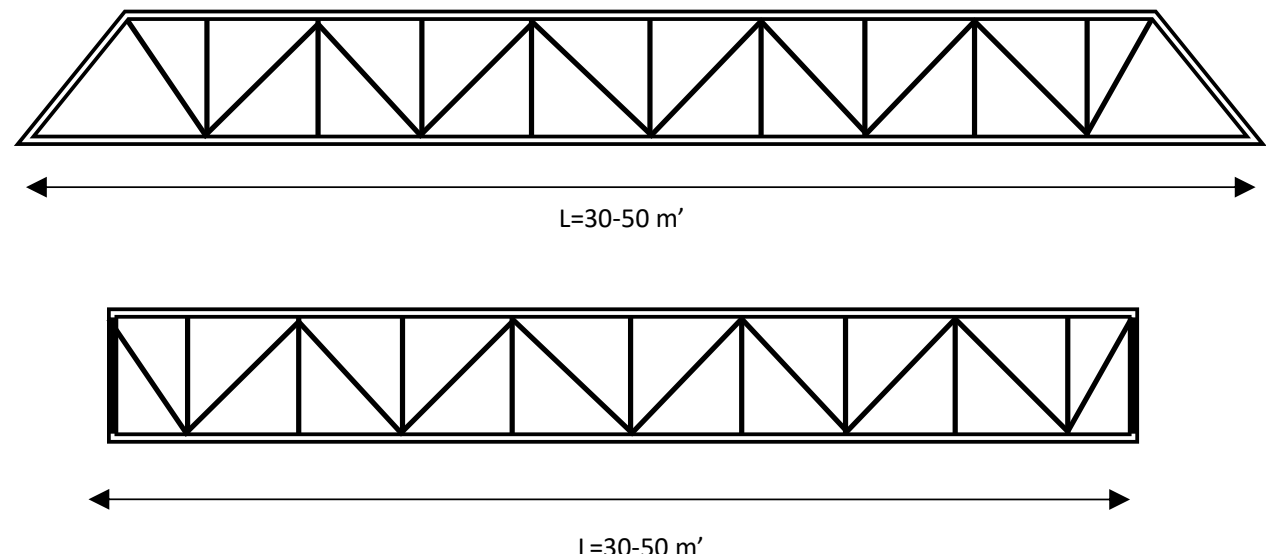

Figura 54. Mbajtësit linear në një drejtim - Kapriatat vijore (Burimi): Bujar Bajçinovci, 2017.

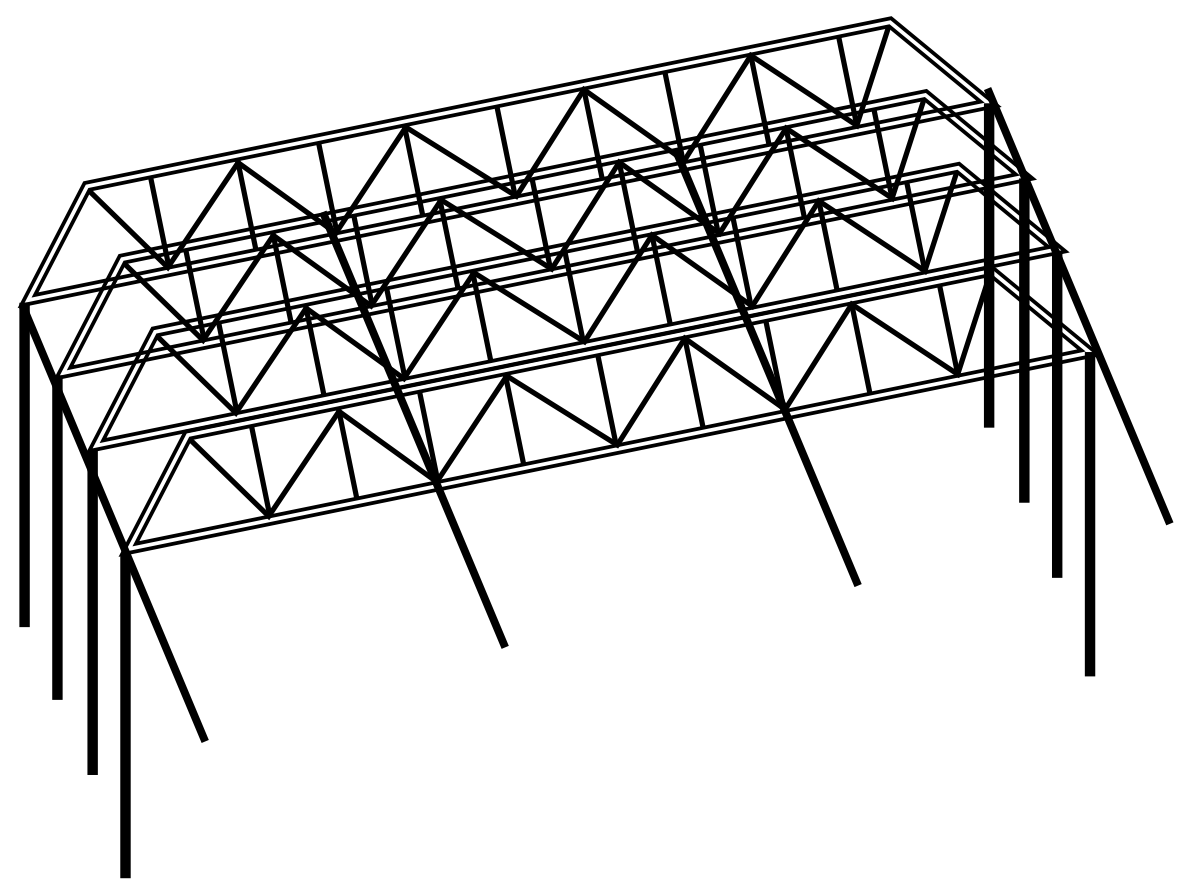

Figura 55. Struktura konstruktive me kapriata vijore (Burimi): Bujar Bajçinovci, 2017. 


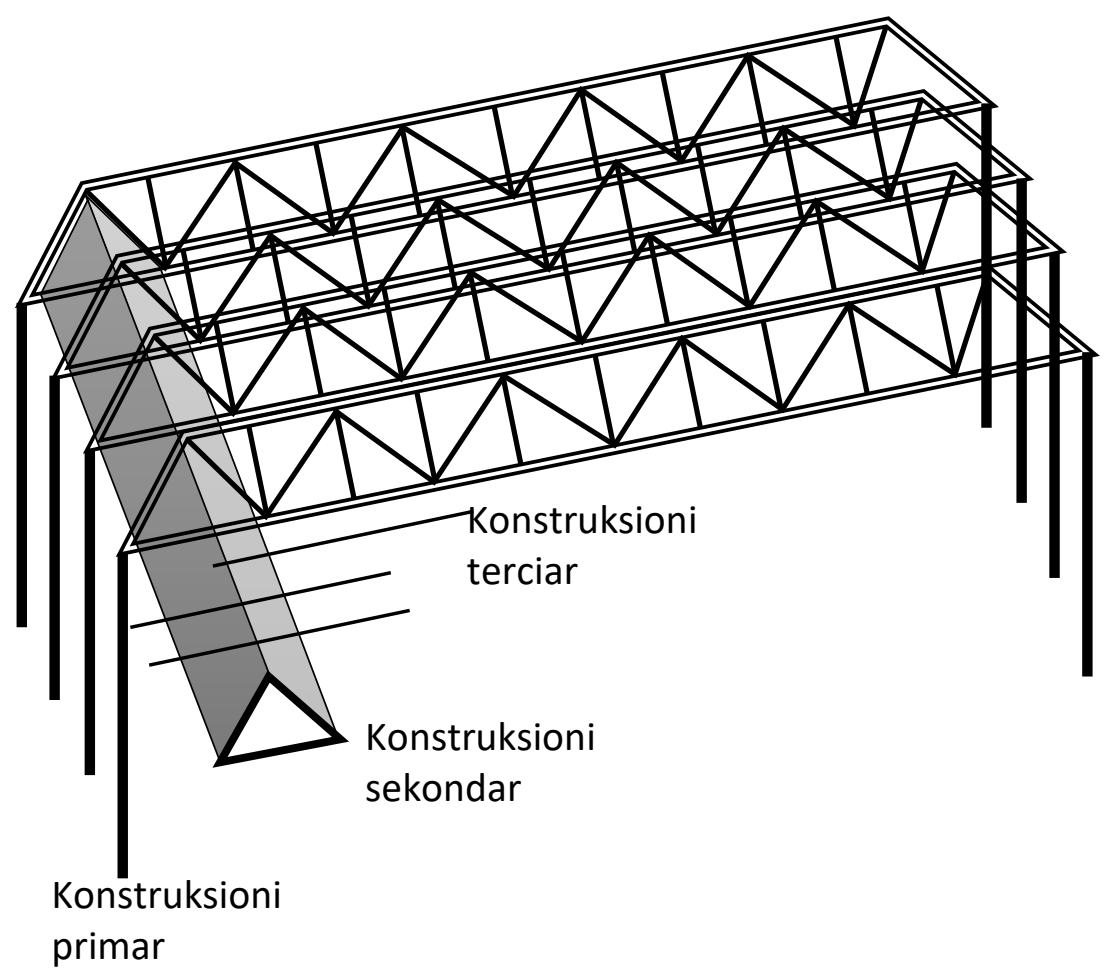

Figura 56. Struktura konstruktive me kapriata vijore (Burimi): Bujar Bajçinovci, 2017.

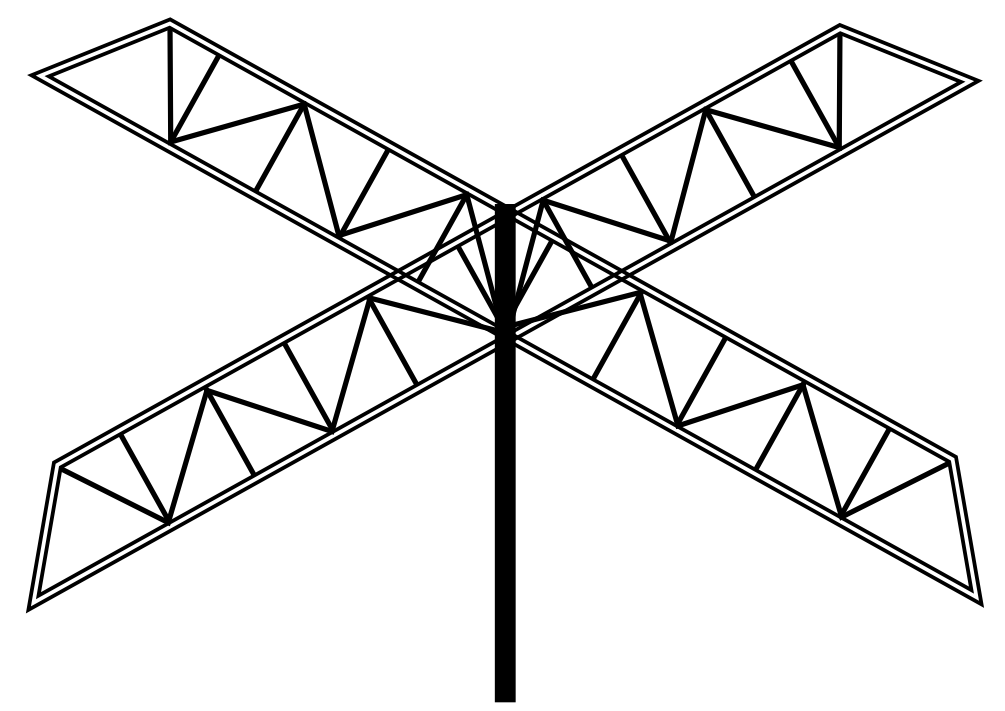

Figura 57. Struktura konstruktive me kapriata vijore në dy drejtime (Burimi): Bujar Bajçinovci, 2017.

Mbajtësit hapësinor linear apo kapriatat hapësinore lineare janë sisteme hapësinore mbajtëse për mbulimin e hapësirave të mëdha drite në hallat industriale, zakonisht na paraqiten me prerje terhore të trajtës trekëndëshë apo edhe drejtëkëndëshe një majë të 
kllapa hapësinore trekëndore për tejkalimin e gamës së madhe të sallave industriale, me mundësinë e realizimit të ndriçimit natyror të orientuar përmes fensterimit të mbajtësve hapësinor.
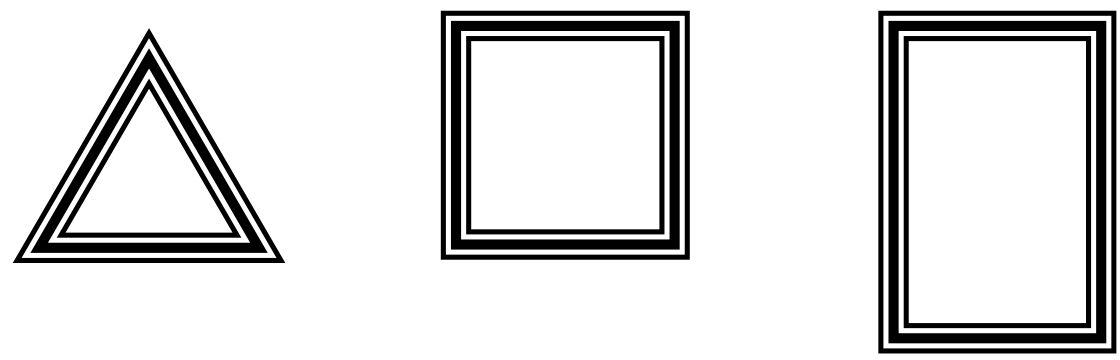

Figura 58. Prerjet terhore të mbajtësve hapësinor linear (Burimi): Bujar Bajçinovci, 2017.
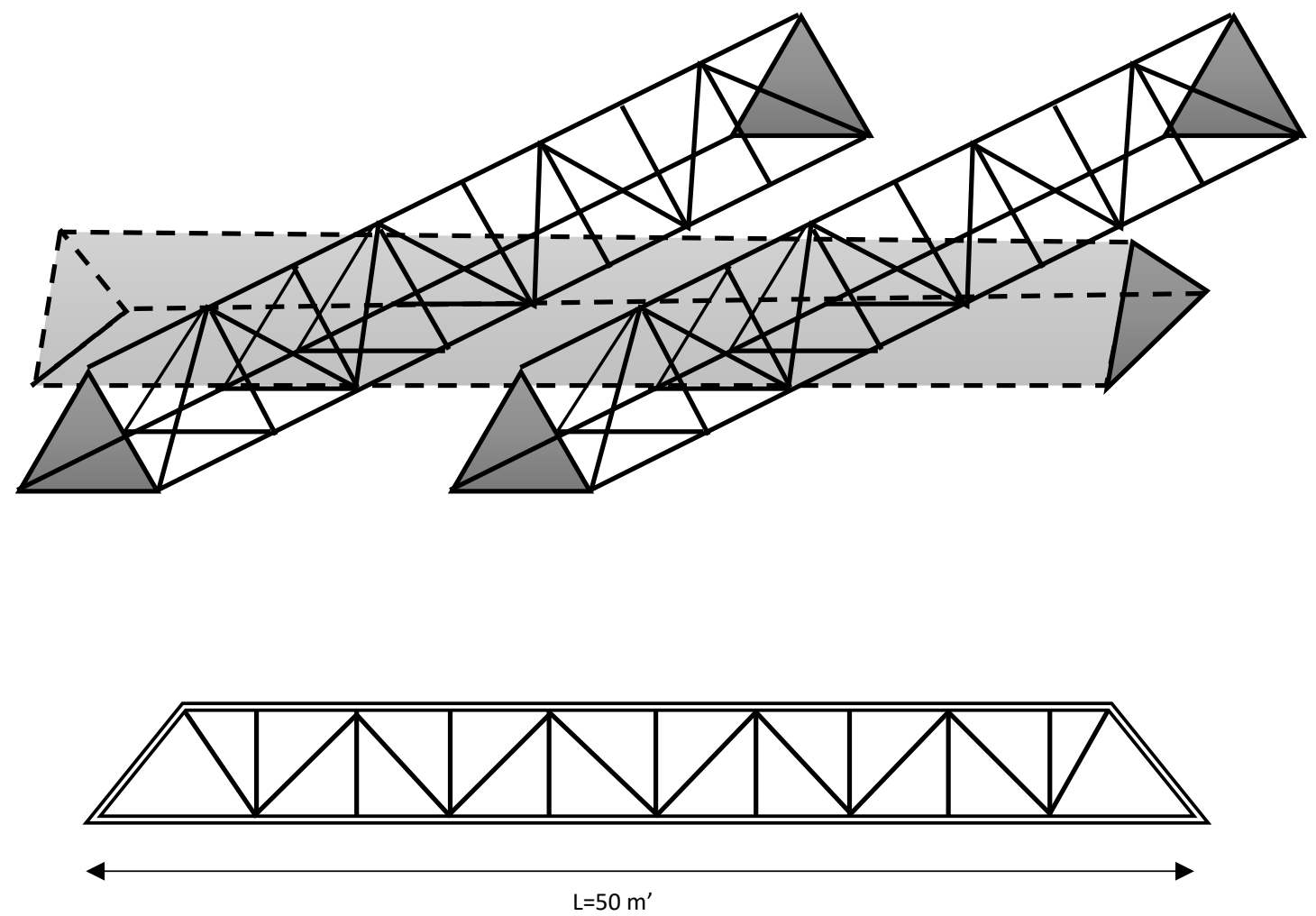

Figura 59. Mbajtësit hapësinor linear - kapriatat hapësinore lineare (Burimi): Bujar Bajçinovci, 2017.

Aplikimi i kapriatave hapësinore ka qenë relativisht i rrallë viteve të mëparshme për shkak të llogaritjes më komplekse të nyjeve të shumta, e sidomos në vendin tonë. Sisoqoft, aktualisht kjo lloj tipologjie e ndërtimit po gjen përdorim të shumtë për shkak të karakteristikave themelore, siç janë: 
1. Reduktim i ndjeshëm i lartësisë konstruktive të kërkuar, trarët dhe trarëzat janë të panevojshëm për shkak se sistemi është hapësinor;

2. Kursime të rëndësishme në çelik në krahasim me ndërtimet lineare;

3. Prodhim më i thjeshtë i strukturës, sepse përsëritë një seri elementesh identike të shufrave;

4. Ngarkesa shpërndahet në të gjithë rrjetin.

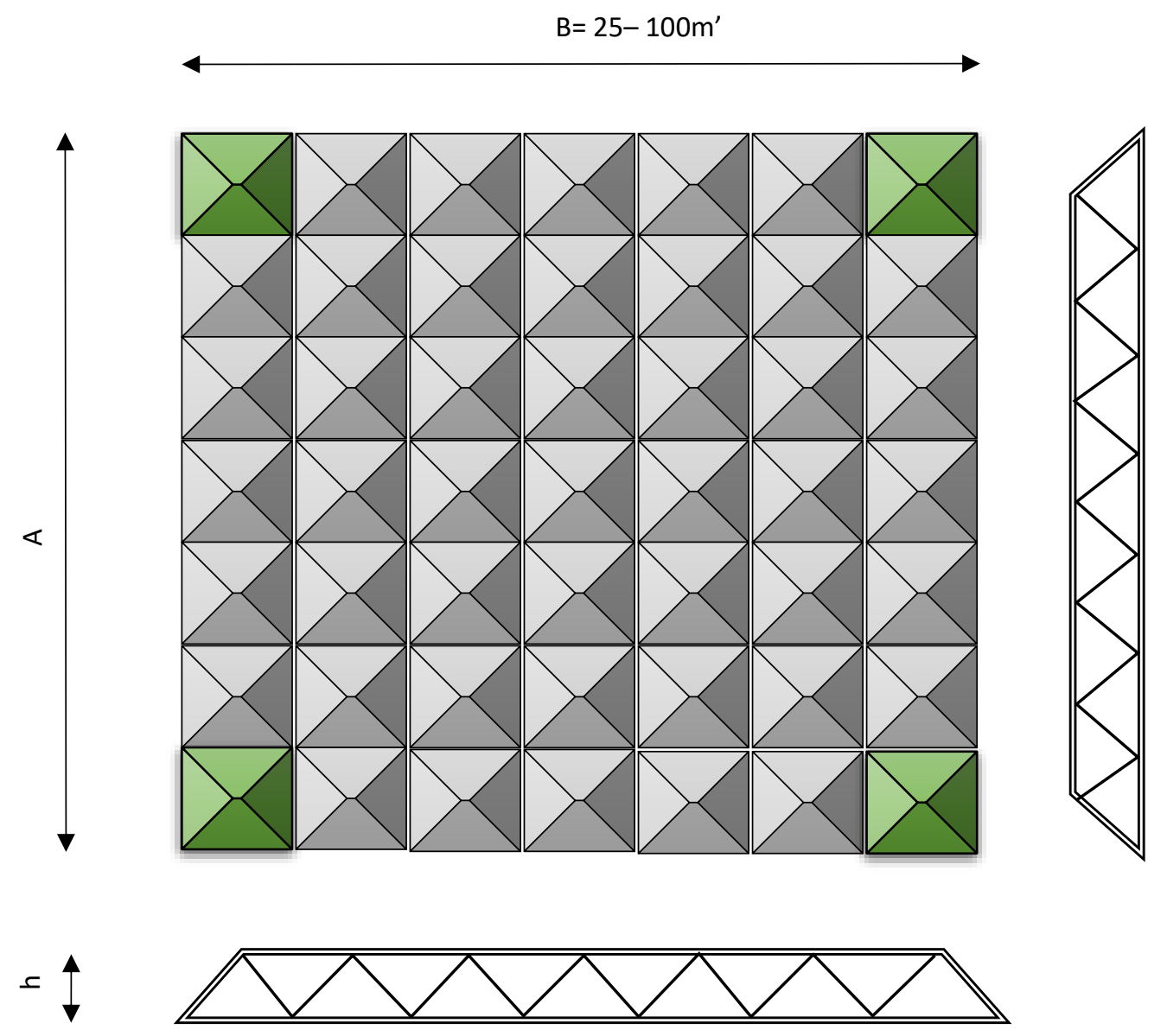

Figura 60. Mbajtësit hapësinor, struktura me mbulesë të madhe hapësirë drite (Burimi): Bujar Bajçinovci, 2017.

$$
\begin{gathered}
\frac{\mathrm{A}}{B} \cong \frac{1}{1,15} \text { apo mё sё miri } \frac{1}{1} \\
h \cong \frac{1}{20} B
\end{gathered}
$$




\subsubsection{Strukturat konstruktive nga druri i lameluar}

Strukturat prej druri të lameluar plotësojnë të gjitha kërkesat industriale të ndërtimit nga aspekti ekonomik, qëllimit dhe të qëndrueshmërisë. Përparësi të veçanta nga këto konstruksione janë: aftësi të lartë mbajtëse kurse kanë peshë të vogël vetanake, mundësi pothuajse të pakufizuara në formësimin dhe përballimin e hapësirave dritë të kërkuara nga projektimi i ndërtesave industriale.

Druri i laminuar është një material ndërtimi i përftuar nga elementë të hollë prej druri me trashësi të barabartë, të vendosura njëra mbi tjetrën, dhe të ngjitura me lloje të caktuara të ngjitësve. Trajtimi sipërfaqësor dhe mbrojtja e strukturave prej druri të lameluar mbron strukturën nga mikroorganizmat, moti, papastërtitë dhe reziku nga zjarri (Bajçinovci, 2017).
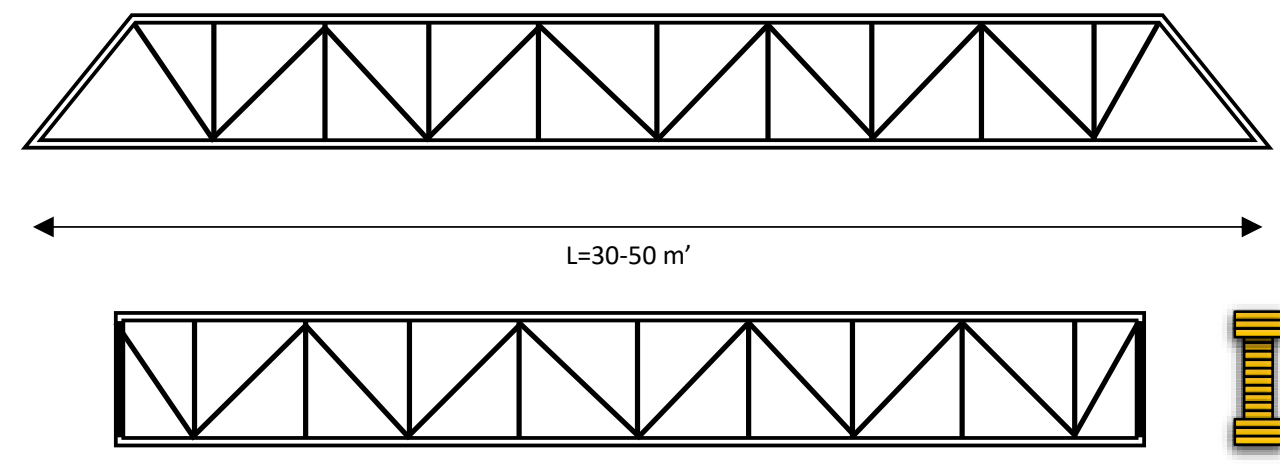

Figura 61. Mbajtësit linear në një drejtim nga druri i lameluar (Burimi): Bujar Bajçinovci, 2017.
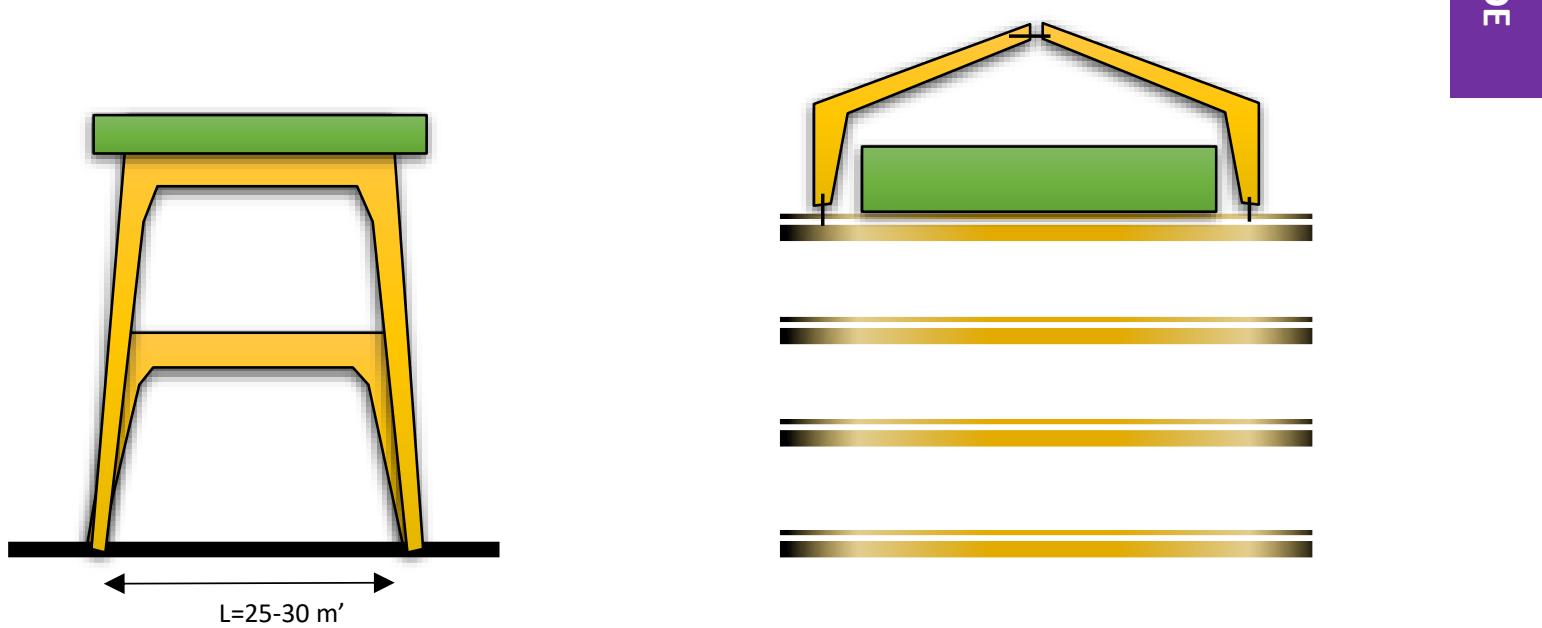

Figura 62. Mbajtësit ram nga druri i lameluar (Burimi): Bujar Bajçinovci, 2017. 


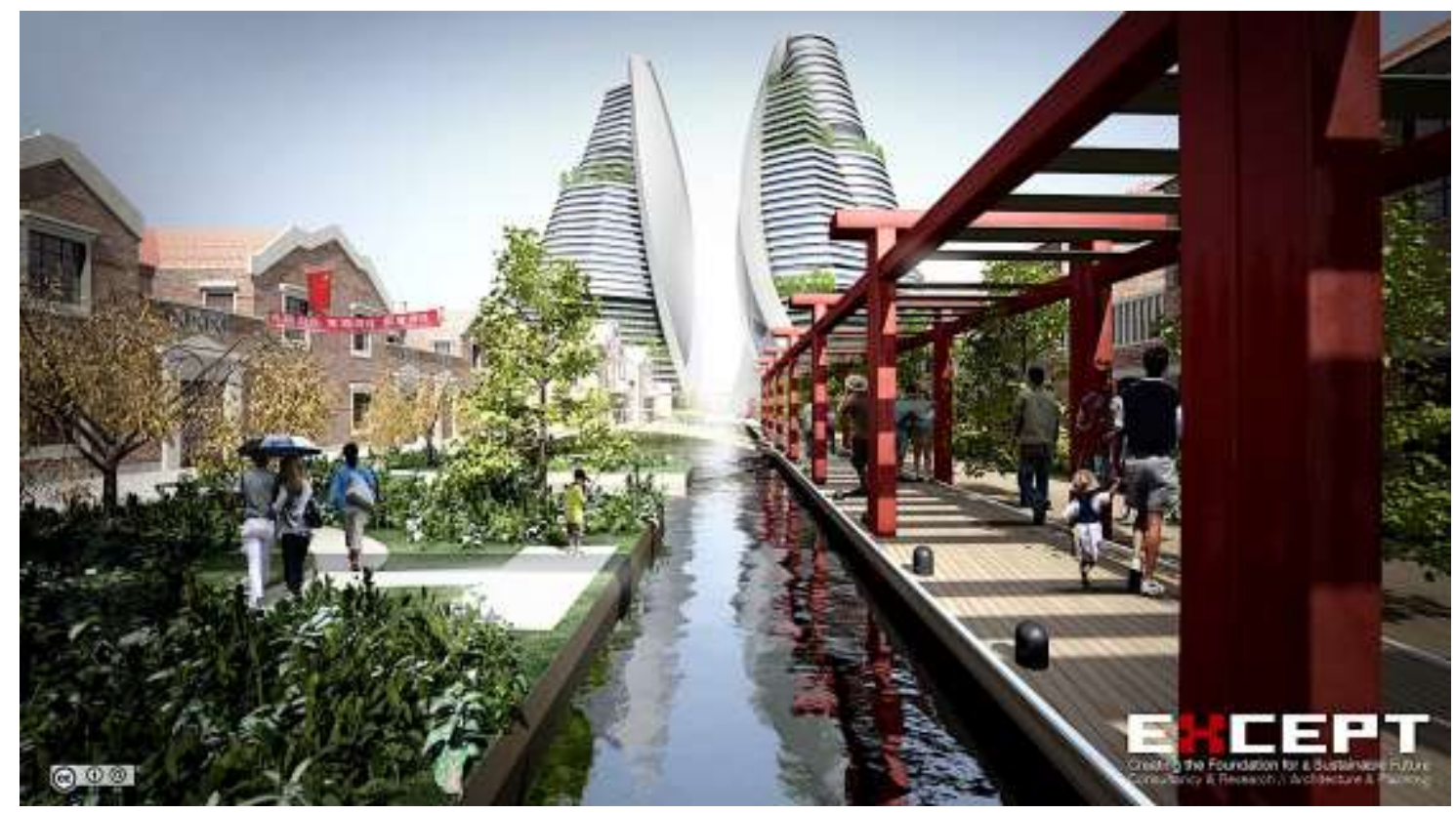

Figura 63. Food Gardens, Channels, Vertical Farms - Shanghai Sustainable Masterplan (Burimi): Except, 2010. (Flickr). E licensuar nga Creative Commons Attribution-ShareAlike 2.0 Generic

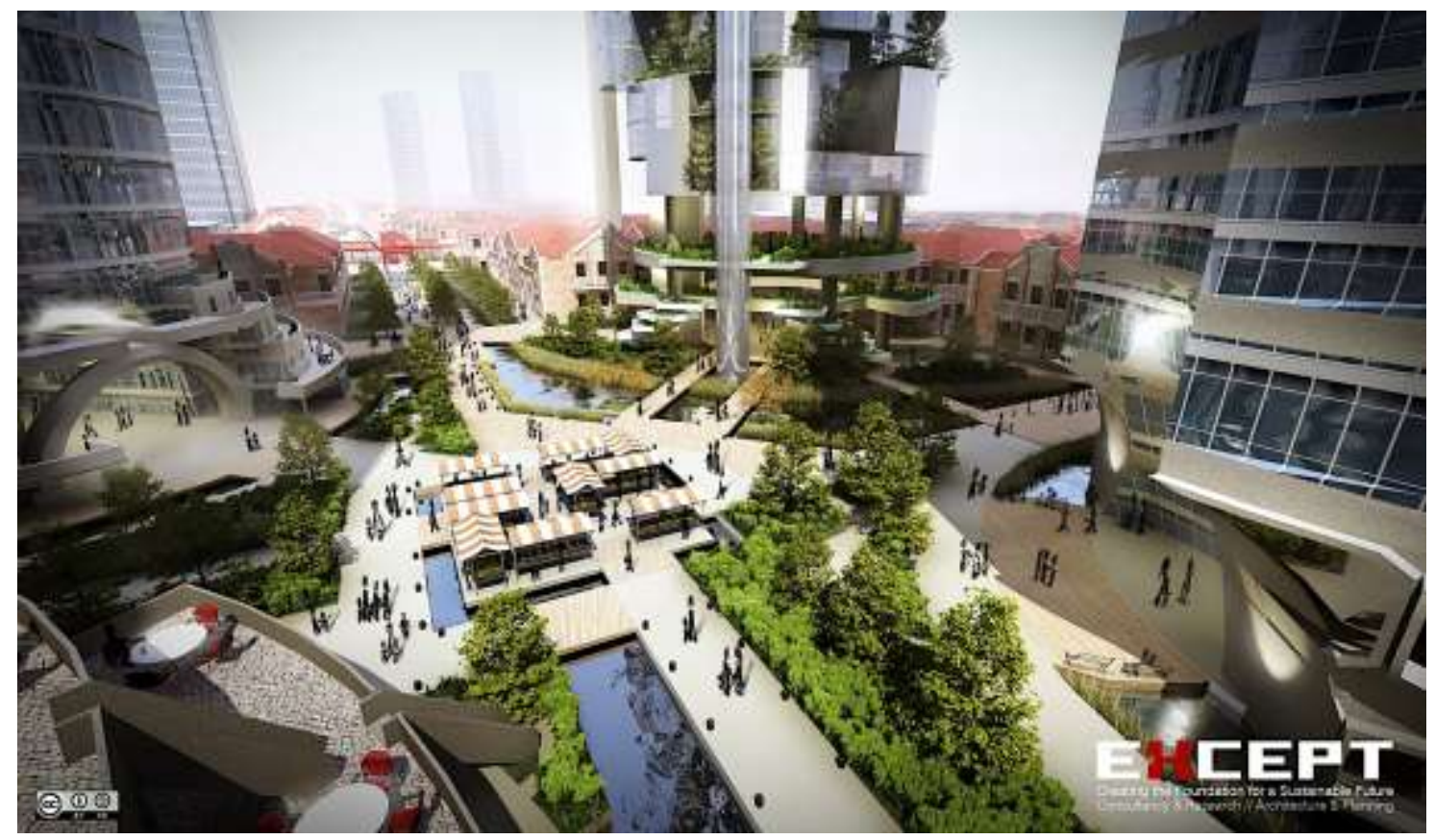

Figura 64. Vertical farms around couryard.

Shanghai Sustainable Masterplan - Central Courtyard.

(Burimi): Except, 2010. (Flickr). E licensuar nga Creative Commons Attribution-ShareAlike 2.0 Generic 


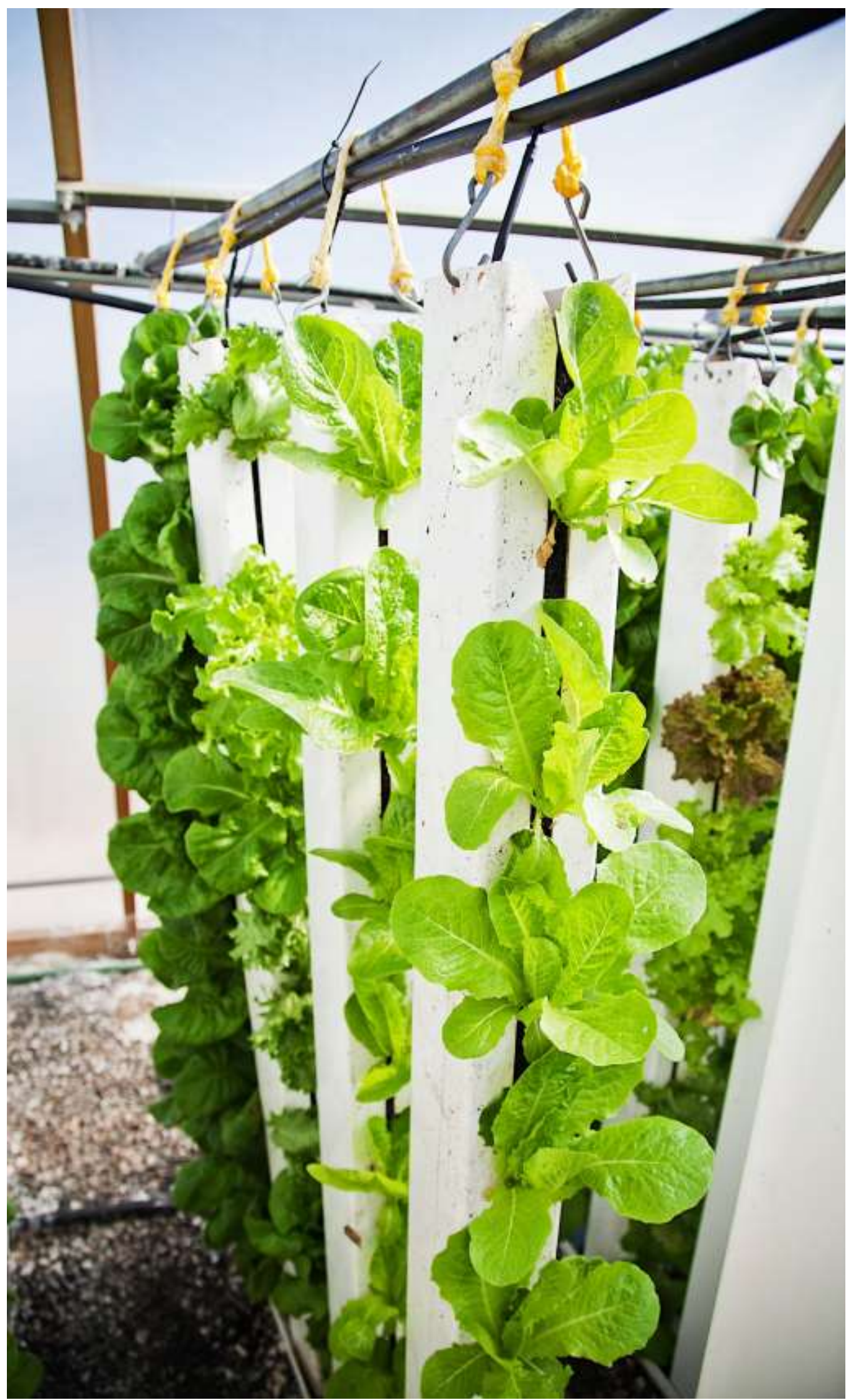

Figura 65. Kultivimi i sallates së gjelber, në farmat vertikale. (Burimi): Bright Agrotech, 2017. Wikimedia Commons. E licensuar nga Creative Commons AttributionShareAlike 4.0 International 


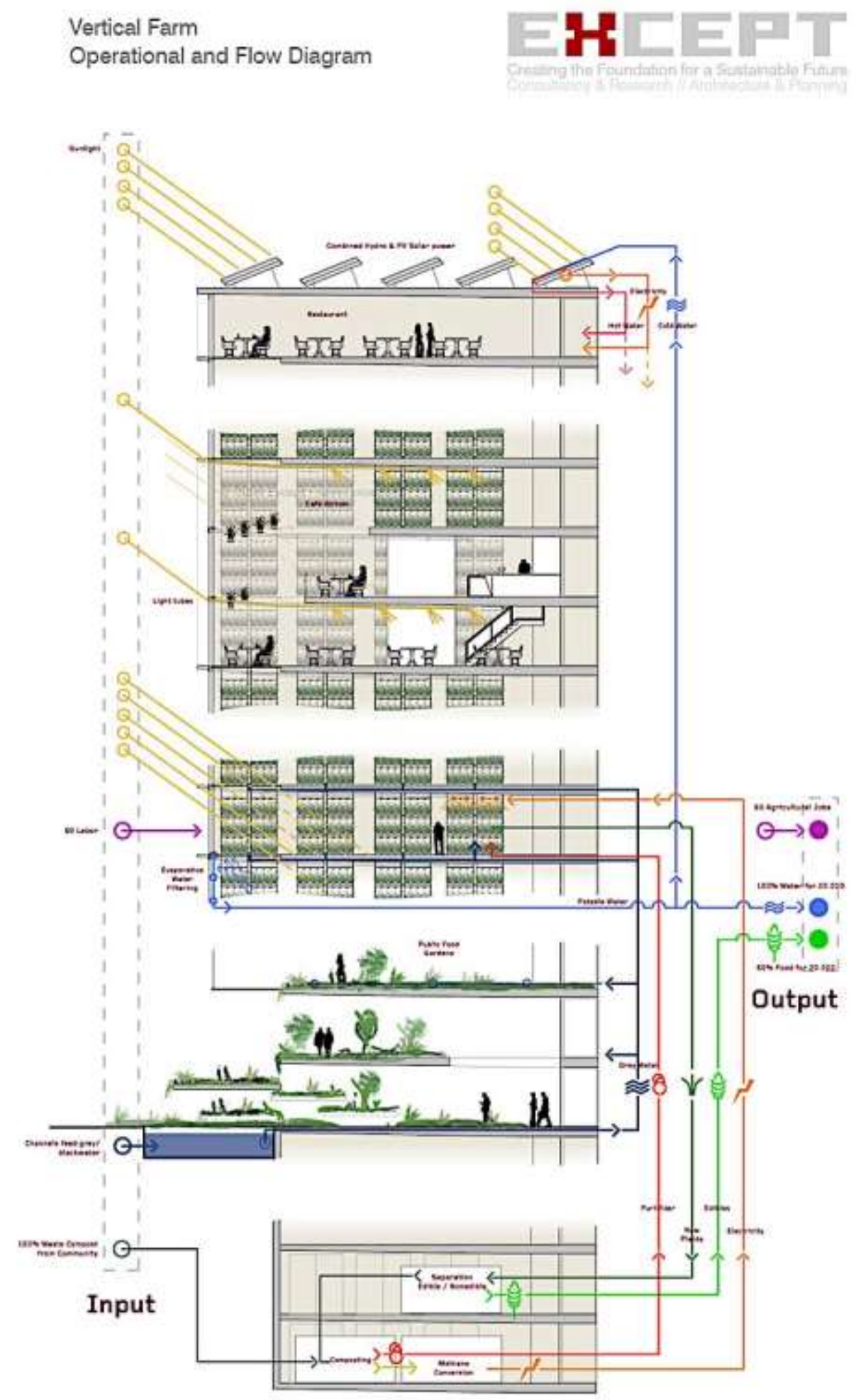

c) (1) (-)

www-except.nI

Figura 66. Vertical Farm operational and flow diagram

(Burimi): Except, 2010. (Flickr). E licensuar nga Creative Commons Attribution-ShareAlike 2.0 Generic 


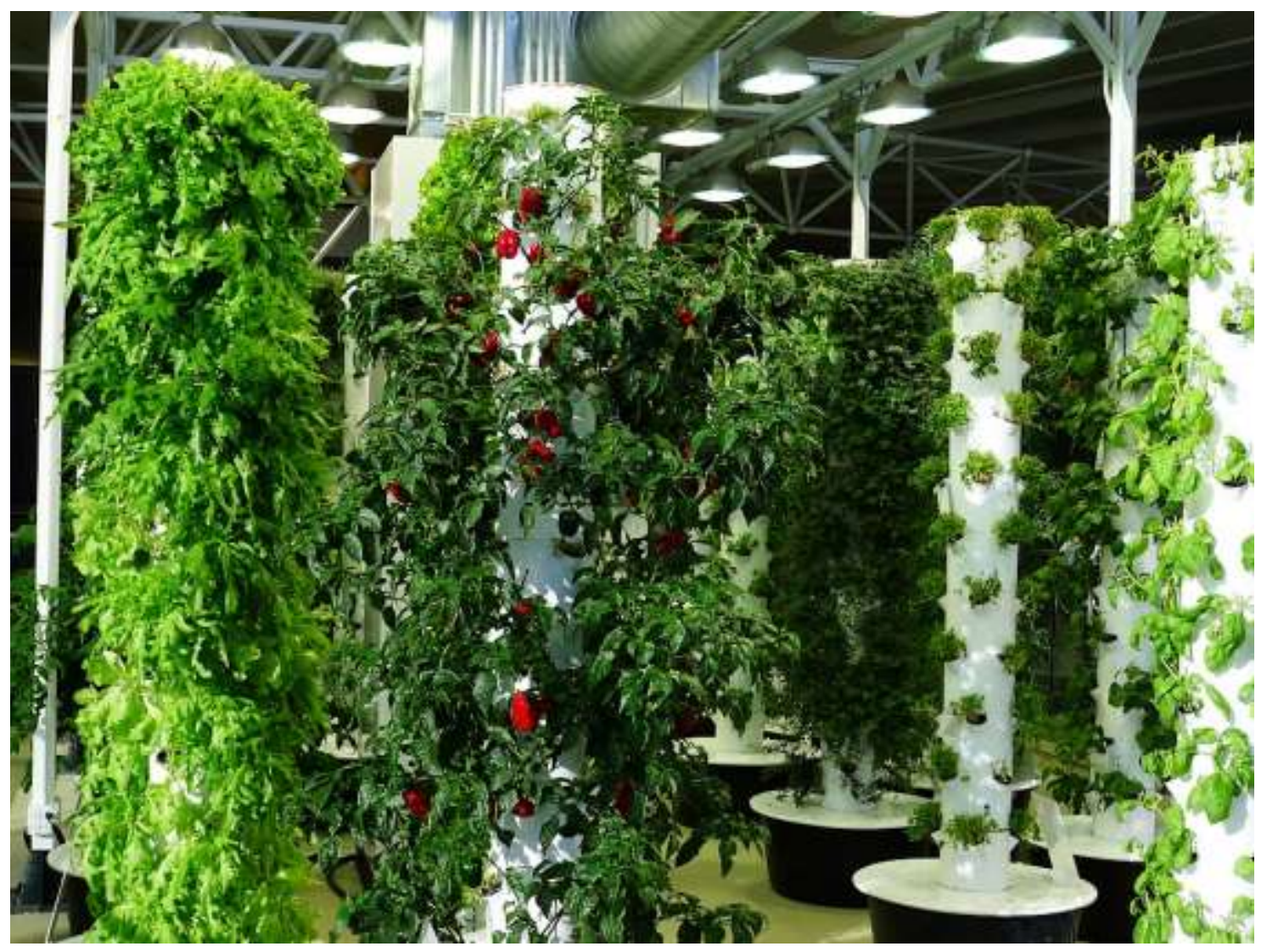

Figura 67. Chicago O'Hare Airport Vertical Farm

(Burimi):chipmunk_1, 2012. (Flickr). E licensuar nga Creative Commons Attribution-ShareAlike 2.0 Generic

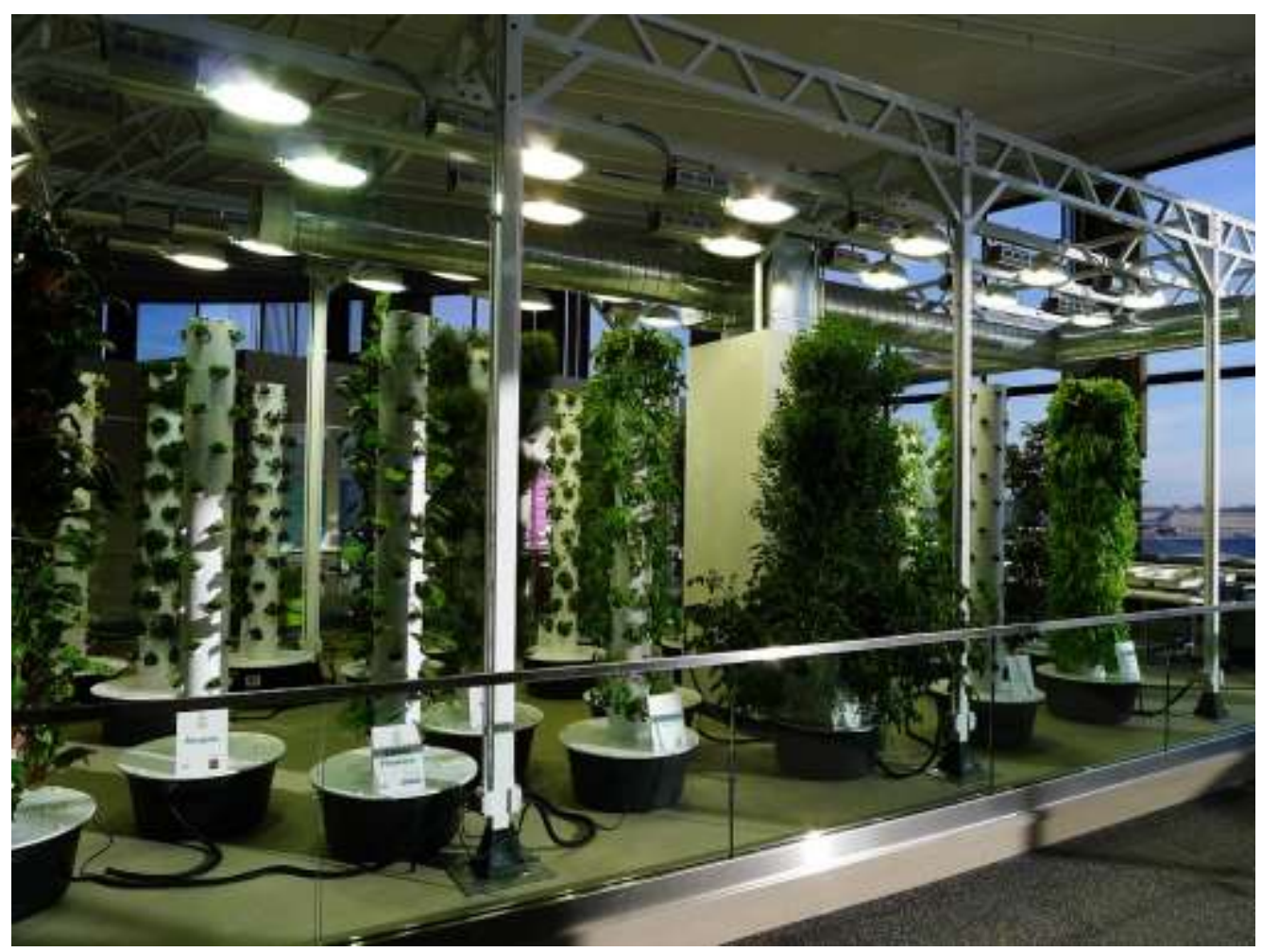

Figura 68. Chicago O'Hare Airport Vertical Farm

(Burimi):chipmunk_1, 2012. (Flickr). E licensuar nga Creative Commons Attribution-ShareAlike 2.0 Generic 


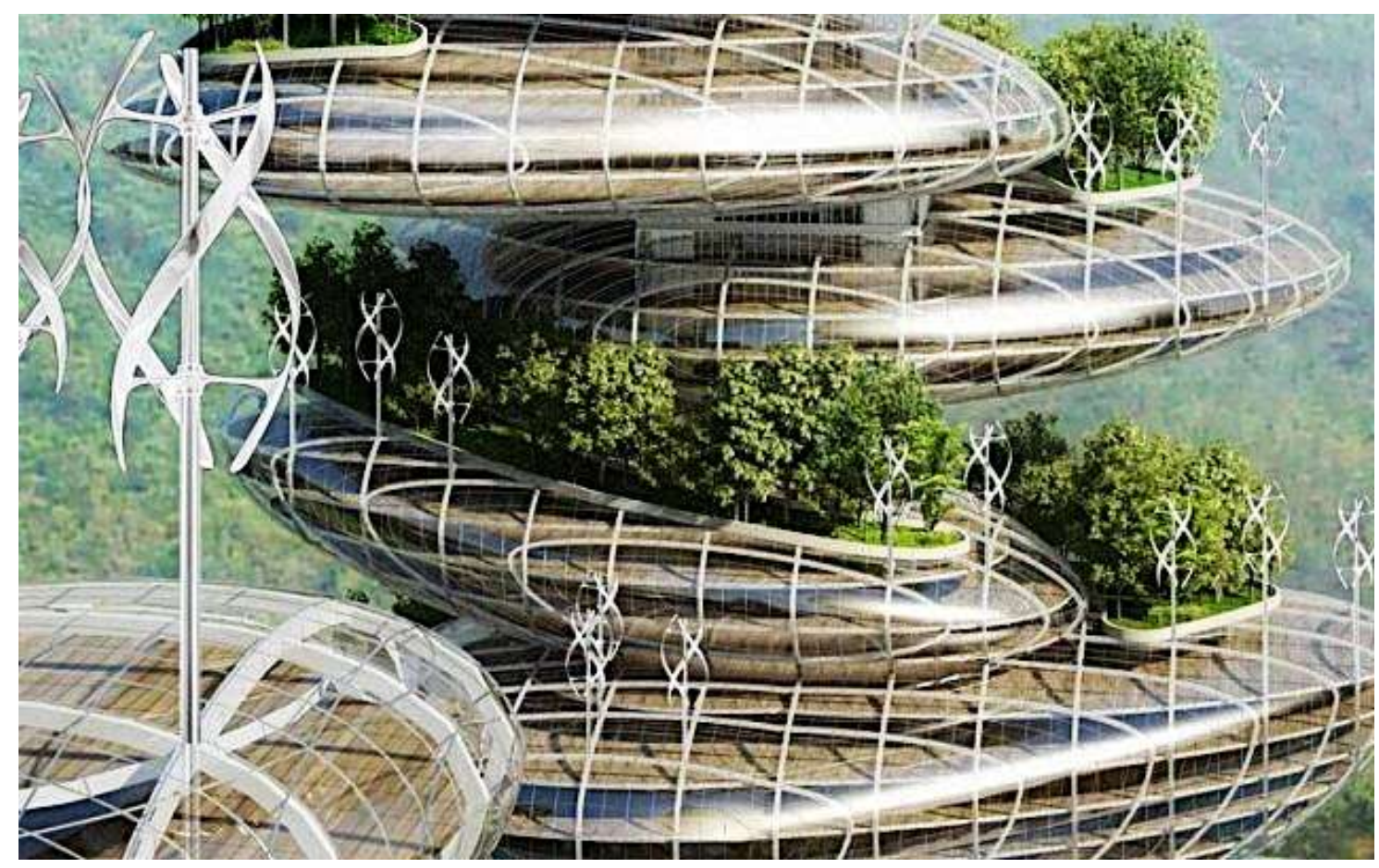

Figura 69. Kultivimi në fermat vertikale

(Burimi): Tutto Giardinaggio, 2016. (Flickr). E licensuar nga Creative Commons Attribution 2.0 Generic

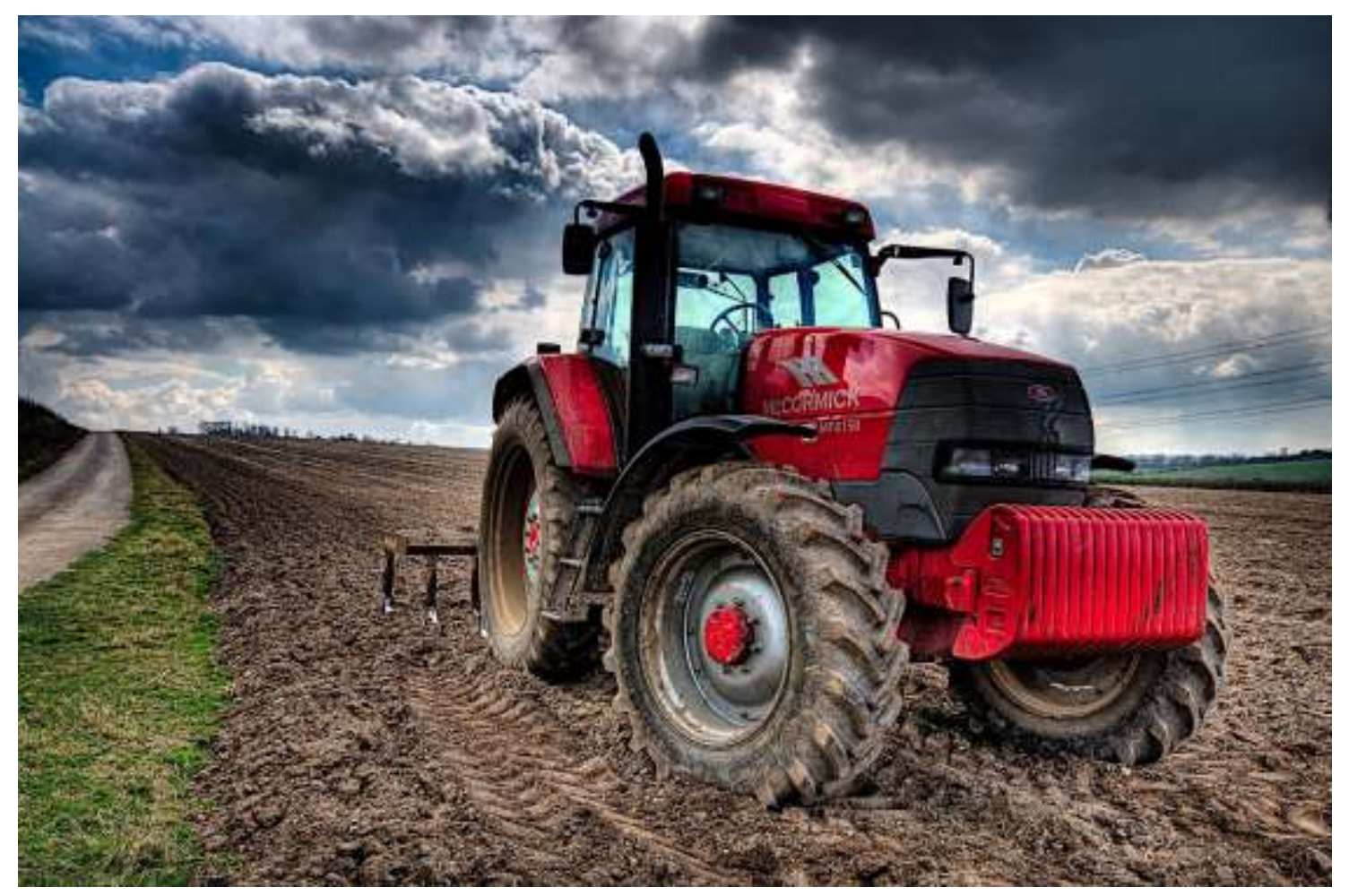

Figura 70. Valley Farm, West Wratting

(Burimi): Andrew Stawarz, 2008. (Flickr). E licensuar nga Creative Commons Attribution-NoDerivs 2.0 Generic 


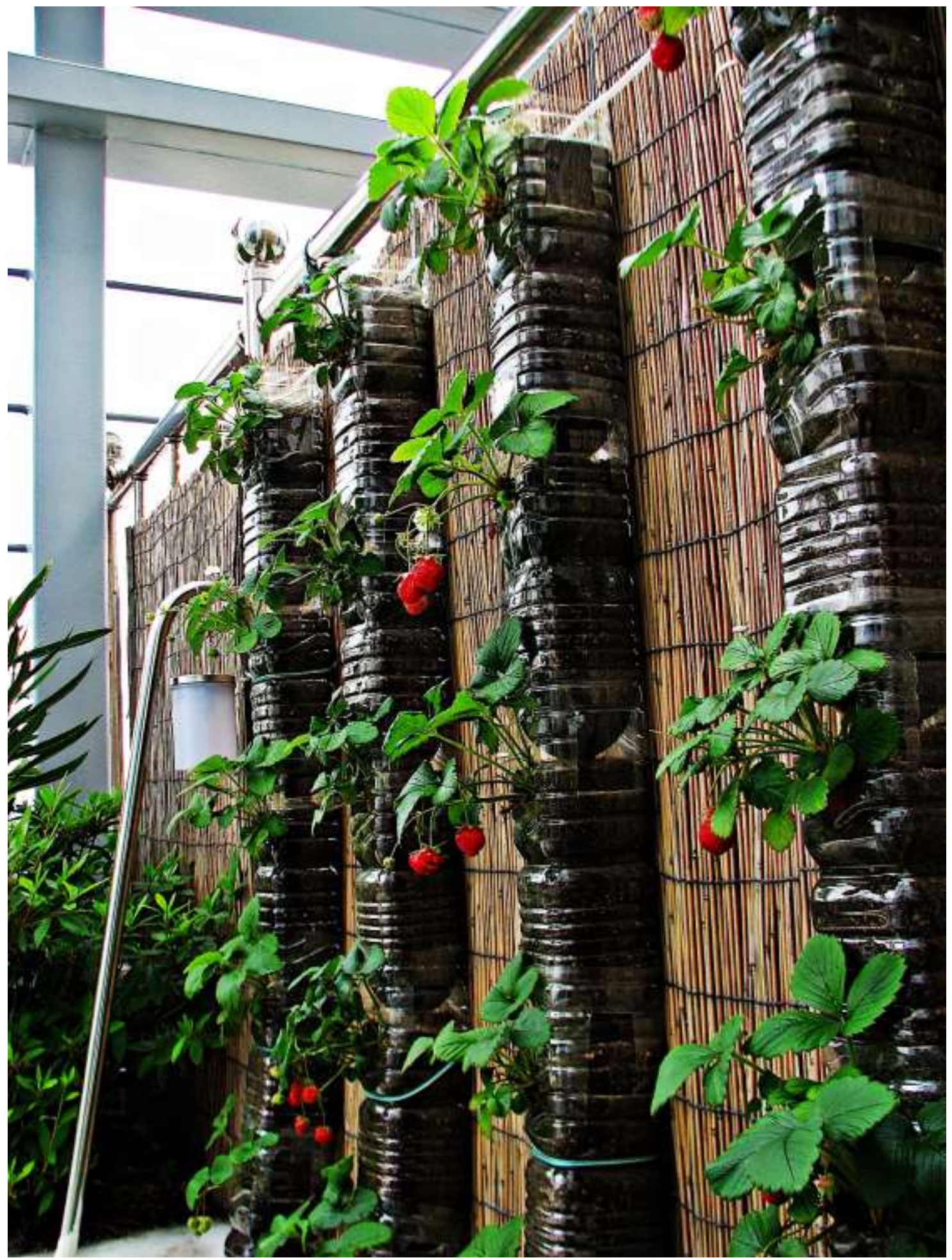

Figura 71. Kultivimi i dredhëzave fermat vertikale

(Burimi): jd_09. 2015. (Flickr). E licensuar nga Creative Commons Attribution 2.0 Generic 
KJO FAQE ËSHTË LËNË QËLLIMISHT E ZBRAZËT! 


\section{INDEKSI I FOTOGRAFIVE - TABELAVE}

\section{FOTOGRAFITË:}

Figura 1. Harta e komunave të Kosovës

(Burimi): RKS. Qeveria

Figura 2. Struktura e fermës sipas madhësisë-sipërfaqja(ha), 2014

(Burimi): ASK Regjistrimi i Bujqësisë 2014

Figura 3. Fermat vertikale, racionalizimi i tokes bujqësore (Burimi): Bujar Bajçinovci, 2017.

Figura 4. Projeksioni i popullates gjatë dekadave të ardhshme (Burimi): UN. Habitat: World Cities Report, 2016. UN, DESA.

UN. Habitat: Living Planet Report, 2015. Bujar Bajçinovci, 2017.

Figura 5. Projeksioni i popullates urbane dhe rurale gjatë dekadave të ardhshme (Burimi): UN. Habitat: World Cities Report, 2016. UN, DESA.

UN. Habitat: Living Planet Report, 2015. Bujar Bajçinovci, 2017.

Figura 6. Racionalizimi i tokës bujqësore në raport me rendimentet e pritura (Burimi): Bujar Bajçinovci, 2017.

Figura 7. Rrugëtimi jo i qendrueshëm i procesit prodhues tek fermat 'klasike' (Burimi): Bujar Bajçinovci, 2017.

Figura 8. Rrugëtimi i qendrueshëm i procesit prodhues tek fermat vertikale (Burimi): Bujar Bajçinovci, 2017.

Figura 9. Fermat Urbane

(Burimi): Bujar Bajçinovci, 2017.

Figura 10. Fermat Urbane etazhore (Burimi): Bujar Bajçinovci, 2017.

Figura 11. Fermat vertikale

(Burimi): Bujar Bajçinovci, 2017.

Figura 12. Sistem - "Aeroponics"

(Burimi): Birkby, J. (2016). Vertical Farming. NCAT. Rivizatuar: Bujar Bajcinovci, 2017. 
Figura 13. Sistem - "Hydroponics"

(Burimi): Birkby, J. (2016). Vertical Farming. NCAT. Rivizatuar: Bujar Bajcinovci, 2017.

Figura 14. Sistem - "Aquaponics"

(Burimi): Birkby, J. (2016). Vertical Farming. NCAT. Rivizatuar: Bujar Bajcinovci, 2017.

Figura 15. Tumë termitesh, struktura e brendshme organizative.

(Burimi): Bujar Bajçinovci. 2015.

Figura 16. Kultivimi i bimësisë në vertikale

(Burimi): Bujar Bajcinovci, 2017.

Figura 17. Struktura kompozicionale e një farme vertikale, hibridizimi i funksioneve (Burimi): Bujar Bajcinovci, 2017.

Figura 18. Prodhimi i produkteve bio (Burimi): Bujar Bajcinovci, 2017.

Figura 19. Modeli i lidhjes së hidrogjenit, në ujë (Burimi): Bujar Bajcinovci, 2017. EJTD Vol. 5, (2). 2017.

Figura 20-21. 3D modeli i ujit në gjendje të lëngshme dhe akulli (Burimi): P99am, 2010. E licensuar nga Creative Commons Attribution ShareAlike 3.0 Unported

Figura 22. Hibridizimi orbital, katër orbitalet SP3

(Burimi): Ifmelero, 2011. E licensuar nga Creative Commons Attribution ShareAlike 3.0 Unported

Figura 23. Neon orbitals

(Burimi): Kurzon, Dmacks, Mortadelo2005, 2006. E licensuar Public Domain

Figura 24. Orbitalet hibride

(Burimi): Averill, A.B. \& Eldredge, P. 2012. Principles of General Chemistry

Figura 25. Formimi i sp orbitaleve hibride

(Burimi): Averill, A.B; Eldredge, P. 2012. Principles of General Chemistry

Figura 26. Formimi i $\mathrm{sp}^{2}$ orbitaleve hibride

(Burimi): Averill, A.B; Eldredge, P. 2012. Principles of General Chemistry

Figura 27. Prishtina, Hibridizimi orbital, zonat pjesëmarrse (Burimi): Imagery (2016 DigitalGlobe, Google, CNES / Astrium, Map data @2016 Google

Figura 28. Struktura hibride organizative. (Burimi): Bujar Bajçinovci. 2016.

Figura 29. Garazha, 24 orë pune, gjatë 24 orëve (Burimi): Bujar Bajçinovci. 2016.

Figura 30. Qendra tregtare 12 orë pune, gjatë 24 orëve (Burimi): Bujar Bajçinovci. 2016. 
Figura 31. Administrata 8 orë pune, gjatë 24 orëve (Burimi): Bujar Bajçinovci. 2016.

Figura 32. Ferma vertikale 24 orë pune, 7 ditë në javë (Burimi): Bujar Bajçinovci. 2017.

Figura 33. Ndërtesa hibride multifunksionale 24/7 ditë në javë. (Burimi): Bujar Bajçinovci. 2016.

Figura 34. Struktura komplekse. Ndërtesa hibride multifunksionale 24/7 në javë. (Burimi): Bujar Bajçinovci. 2017.

Figura 35. Zonat hibride multifunksionale. (Burimi): Bujar Bajçinovci. 2017.

Figura 36. Zonat hibride multifunksionale. (Burimi): Bujar Bajçinovci. 2017.

Figura 37. Zonat hibride multifunksionale. (Burimi): Bujar Bajçinovci. 2017.

Figura 38. Variacionet. Zonat hibride multifunksionale. (Burimi): Bujar Bajçinovci. 2017.

Figura 39. Dekomponimi i sipërfaqeve horizontale dhe vertikale e një tërësie komplekse hibride.

(Burimi): Bujar Bajçinovci. 2017.

Figura 40. Variacionet. Zonat hibride multifunksionale. Dekomponimi i sipërfaqeve horizontale dhe vertikale e një tërësie

(Burimi): Bujar Bajçinovci. 2017.

Figura 41. Dekomponimi i sipërfaqeve horizontale dhe vertikale e një tërësie (Burimi): Bujar Bajçinovci. 2017.

Figura 42. Dekomponimi i sipërfaqeve horizontale dhe vertikale e një tërësie (Burimi): Bujar Bajçinovci. 2017.

Figura 43. Variacionet. Zonat hibride multifunksionale. Dekomponimi i sipërfaqeve horizontale dhe vertikale e një tërësie

(Burimi): Bujar Bajçinovci. 2017.

Figura 44. Variacionet, trajtat. Komponimi i sipërfaqeve horizontale të një tërësie. (Burimi): Bujar Bajçinovci. 2016.

Figura 45. Variacionet, trajtat. Komponimi i sipërfaqeve horizontale të një tërësie. (Burimi): Bujar Bajçinovci. 2016.

Figura 46. Variacionet, trajtat. Komponimi i sipërfaqeve horizontale të një tërësie. (Burimi): Bujar Bajçinovci. 2016. 
Figura 47. Variacionet, trajtat. Komponimi i sipërfaqeve horizontale të një tërësie. (Burimi): Bujar Bajçinovci. 2016. (Burimi): Bujar Bajçinovci. 2016.

Figura 48. Variacionet, trajtat. Komponimi i sipërfaqeve horizontale. (Burimi): Bujar Bajçinovci. 2016.

Figura 49. Komponimi i sipërfaqeve horizontale dhe vertikale e një tërësie në 3D. (Burimi): Bujar Bajçinovci. 2016.

Figura 50. Komponimi i volumeneve në një tërësi hibride - 3D. (Burimi): Bujar Bajçinovci. 2016.

Figura 51. Komponimi i volumeneve në një tërësi hibride - 3D. (Burimi): Bujar Bajçinovci. 2016.

Figura 52. Komponimi i volumeneve në një tërësi hibride - 3D. (Burimi): Bujar Bajçinovci. 2016.

Figura 53. Struktura ram nga betonarmea (Burimi): Bujar Bajçinovci. 2017.

Figura 54. Mbajtësit linear në një drejtim - Kapriatat vijore (Burimi): Bujar Bajçinovci, 2017.

Figura 55. Struktura konstruktive me kapriata vijore (Burimi): Bujar Bajçinovci, 2017.

Figura 56. Struktura konstruktive me kapriata vijore (Burimi): Bujar Bajçinovci, 2017.

Figura 57. Struktura konstruktive me kapriata vijore në dy drejtime (Burimi): Bujar Bajçinovci, 2017.

Figura 58. Prerjet terhore të mbajtësve hapësinor linear (Burimi): Bujar Bajçinovci, 2017.

Figura 59. Mbajtësit hapësinor linear - kapriatat hapësinore lineare (Burimi): Bujar Bajçinovci, 2017.

Figura 60. Mbajtësit hapësinor, struktura me mbulesë të madhe hapësirë drite (Burimi): Bujar Bajçinovci, 2017.

Figura 61. Mbajtësit linear në një drejtim nga druri i lameluar (Burimi): Bujar Bajçinovci, 2017.

Figura 62. Mbajtësit ram nga druri i lameluar (Burimi): Bujar Bajçinovci, 2017.

Figura 63. Food Gardens, Channels, Vertical Farms - Shanghai Sustainable Masterplan (Burimi): Except, 2010. (Flickr). E licensuar nga Creative Commons Attribution-ShareAlike 2.0 Generic 
Figura 64. Vertical farms around couryard.

Shanghai Sustainable Masterplan - Central Courtyard.

(Burimi): Except, 2010. (Flickr). E licensuar nga Creative Commons Attribution-ShareAlike 2.0 Generic

Figura 65. Kultivimi i sallates së gjelber, në farmat vertikale.

(Burimi): Bright Agrotech, 2017. Wikimedia Commons. E licensuar nga Creative Commons AttributionShareAlike 4.0 International

Figura 66. Vertical Farm operational and flow diagram

(Burimi): Except, 2010. (Flickr). E licensuar nga Creative Commons Attribution-ShareAlike 2.0 Generic

Figura 67. Chicago O'Hare Airport Vertical Farm

(Burimi):chipmunk_1, 2012. (Flickr). Elicensuar nga Creative Commons Attribution-ShareAlike 2.0 Generic

Figura 68. Chicago O'Hare Airport Vertical Farm

(Burimi):chipmunk_1, 2012. (Flickr). E licensuar nga Creative Commons Attribution-ShareAlike 2.0 Generic

Figura 69. Kultivimi në fermat vertikale

(Burimi): Tutto Giardinaggio, 2016. (Flickr). E licensuar nga Creative Commons Attribution 2.0 Generic

Figura 70. Valley Farm, West Wratting

(Burimi): Andrew Stawarz, 2008. (Flickr). E licensuar nga Creative Commons Attribution-NoDerivs

2.0 Generic

Figura 71. Kultivimi i dredhëzave fermat vertikale

(Burimi): jd_09. 2015. (Flickr). E licensuar nga Creative Commons Attribution 2.0 Generic 


\section{TABELAT:}

Tabela 1. Pjesëmarrja në \% e sektorit të energjisë dhe lëndëve të para në krijimin e BPV (Burimi): Muhamet Sadiku; "Sistemi ekonomik dhe zhvillimi i Kosovës", Riinvest, Prishtinë, 1997.

Tabela 2. Indikatorët e industrializimit / pjesëmarrja e industrisë në krijimin e BPV (Burimi): Aktivitetet dhe zhvillimi demokratik i Kosovës, Riinvest, 1997.

Tabela 3. Sipërfaqja e shfrytëzuar e tokës bujqësore 2015 (Burimi): Anketa e Ekonomive Shtepiake Bujqësore 2015, Departamenti për Vreshtari dhe Verëtari, përpunuar nga DAESB-MBPZHR.

Tabela 4. Indeksi vjetor i çmimeve të inputeve bujqësore $2010-2015(2010=100)$ (Burimi): ASK (Indeksi i çmimeve të inputeve dhe çmimet në bujqësi), përpunuar nga DAESB - MBPZHR

Tabela 5. Struktura e fermave sipas madhësisë, Nr. i Ekonomive Bujqësore në vitin 2014 (Burimi): ASK Regjistrimi i Bujqësisë 2014

Tabela 6. Industria ushqimore dhe agro bizneset për vitet 2011-2015 (Burimi): ASK - Departamenti i Statistikave Ekonomike

Tabela 7. Llogaritë ekonomitë për bujqësi me çmime aktuale, në mil. $€$ (Burimi): ASK, Llogaritë Ekonomike për Bujqësi, përpunuar nga DAESB-MBPZHR

Tabela 8. Sipërfaqja, prodhimtaria dhe rendimenti i drithërave, 2009-2015 (Burimi): ASK, Anketa e ekonomive shtëpiake bujqësore; ASK-Vlerësime të ekspertëve. Regjistrimi i Bujqësisë.

Tabela 9. Sipërfaqja me perime, 2009 - 2015 (Burimi): ASK, Anketa e ekonomive shtëpiake bujqësore; ASK-Vlerësime të ekspertëve. Regjistrimi i Bujqësisë.

Tabela 10. Sipërfaqja me pemë, 2009 - 2015 (Burimi): ASK, Anketa e ekonomive shtëpiake bujqësore; ASK-Vlerësime të ekspertëve. Regjistrimi i Bujqësisë.

Tabela 11. Bilanci i furnizimit për rrush tryeze, 2011 - 2015

(Burimi): ASK, , Statistikat e Tregtisë së Jashtme; Departamenti për Vreshtari dhe Verëtari - MBPZHR; kalkulime nga DAESB - MBPZHR

Tabela 12. Sipërfaqja, prodhimtaria dhe rendimenti i kulturave foragjere dhe drithërave të kositura të gjelbëra, 2009-2015

(Burimi): ASK, Anketa e ekonomive shtëpiake bujqësore; ASK-Vlerësime të ekspertëve. Regjistrimi i Bujqësisë.

Tabela 13. Sipërfaqja, prodhimtaria dhe rendimenti i kulturave industriale, 2014-2015 (Burimi): ASK - Regjistrimi i Bujqësisë 2014; Anketa e Ekonomive Bujqësore 2015 
Tabela 14. Fondi dhe struktura e gjedhëve, 2009-2015

(Burimi): ASK - Anketa e ekonomive shtëpiake bujqësore.

ASK-Vlerësime të ekspertëve . Regjistrimi i Bujqësisë ('14); Vlerësime DAESB ('09-'13).

Tabela 15. Bilanci i furnizimit, qumështi dhe produktet e qumështit të lopës, 2011-2015 (Burimi): ASK - Anketa e ekonomive shtëpiake bujqësore ('09,'12'13,'15 ); ASK-Vlerësime të ekspertëve; Regjistrimi i Bujqësisë ('14); ASK, Statistikat e Tregtisë së Jashtme; kalkulime nga DAESB - MBPZHR

Tabela 16. : Numri i shpezëve dhe vezëve 2009-2015, në 1000 krerë (Burimi): ASK - Anketa e ekonomive shtëpiake bujqësore ('09,'12'13,'15 ); ASK-Vlerësime të ekspertëve; Regjistrimi i Bujqësisë Vlerësime: DPBT ('09-'11), SHPUK ('12-'13), DAESB ('14-'15)

Tabela 17. Popullsia e botës sipas madhësisë të vendbanimeve, 2016 dhe 2030 (Burimi): UN. Habitat: World Cities Report, 2016. Bujar Bajçinovci, 2017.

Tabela 18. Qytetet sipas numrit të banorëve, 2016 dhe 2030 (Burimi): UN. Habitat: World Cities Report, 2016. Bujar Bajçinovci, 2017 
KJO FAQE ËSHTË LËNË QËLLIMISHT E ZBRAZËT! 


\section{LITERATURA}

1. Abel, C.(2004). Architecture,Technology and Process. Oxford, UK: Elsevier

2. ACRP, report 130. (2015). Guidebook for Airport Terminal Restroom Planning and Design. Federal Aviation Administration, (C) National Academy of Sciences. USA.

3. Alfeld, E, L. (1995). Urban dynamics-The first fifty years. System Dynamics ReviewVol. 11, no. 3: 199-217. John Wiley \& Sons, ltd.

4. Agjencia e Statistikave të Kosovës. Popullsia e Kosovës 2014. 2015.

5. Audi, R. (2011). Epistemology. London, UK. New York. USA : Routledge. Tailor \& Francis Group.

6. Asociacioni i Komunave të Kosovës. Deklaratë parimore: Planifikimi urban dhe rural. 2010.

7. ASK. (2017). Statistikat e transportit dhe telekomunikacionit TM $1-2016$. Ministria e Punëve të Brendshme

8. Asistenca evropiane $128976 / \mathrm{C} / \mathrm{SER} / \mathrm{KOS}$

9. Averill, A.B; Eldredge, P. (2012). Principles of General Chemistry

10. Batty, M., Torrens M.P. (2005). Modelling and prediction in a complex world. London, UK. Salt Lake City, USA : Elsevier.

11. Bajçinovci, B., Thaçi, K. (2016). Heritage and Artistic Boon: Valuing Prizren Castle. Journal of Science, Humanities and Arts. JOSHA. ISSN: 2364-0626. Vol. (3), Is. 5. 2016. DOI: 10.17160/josha.3.5.228

12. Bajçinovci, B., Jerliu, F. (2016). Integrated Design as an Evolutive Transdisciplinary Strategy. European Journal of Technology and Design, Vol. (13), Is. 3: pp. 90-98. 2016. DOI: 10.13187/ejtd.2016.13.90

13. Bajçinovci, B. (2016). Challenges of Architectural Design in relation to Environment and Air Pollution. A Case study: Prishtina's first public parking Garage. Journal of Science, Humanities and Arts. JOSHA. ISSN: 2364-0626. Vol. (3), Is. 7. 2016. DOI: 10.17160/josha.3.7.254

14. Bajçinovci, B. (2016). Hybrid Structures as a Symbiotic Bond of Art and science. Journal of Science, Humanities and Arts. JOSHA. ISSN: 2364-0626. Vol. (3), Is. 5. 2016. DOI: 10.17160/josha.3.5.233

15. Bajçinovci, B., Jerliu, F. (2016). Urban Resettlements and Environmental Engineering as a Context for Human Development. A Case Study: Hade. Journal of Applied Engineering Sciences, Vol. 6(19), Is. 2/2016, Art. No. 203, pp. 7-14. 2016. DOI: 10.1515/jaes-2016-0011

16. Bajçinovci, B. (2016). Architectural Conceptual Design - the Sustainable Shopping Malls Structures. European Journal of Technology and Design, Vol. (14), Is. 4: pp. 136-143. 2016. DOI: 10.13187/ejtd.2016.14.136

17. Bajçinovci, B., Jerliu, F. (2016). Achieving Energy Efficiency in Accordance with Bioclimatic Architecture Principles. Environmental and Climate Technologies. Vol. (18), pp. 54-63. 2016. DOI: 10.1515/rtuect-2016-0013 
18. Bajçinovci, B., Thaçi, K., B. Q. Bajçinovci (2016). Architectural Reflection on Italo Calvino's Invisible Cities. Journal of Science, Humanities and Arts. JOSHA. Vol. (4), Is. 1. 2017. DOI: 10.17160/josha.4.1.261

19. Bajçinovci, B., Jerliu, F. (2016). Complexity of Iterative Model - Architectural Integrated Design as an Evolutive Transdisciplinary Strategy. Case Study: A City Without a River. Journal of Science, Humanities and Arts. JOSHA. ISSN: 2364-0626. Vol. (4), Is. 1. 2017. DOI: 10.17160/josha.4.1.264

20. Bajçinovci, B. (2017). Ecological Factors Regarding to the Site Selection and Architectural Design of Parking Garages. European Journal of Technology and Design, Vol. (5), Is. 1. 2017. DOI: 10.13187/ejtd.2017.1

21. Bajçinovci, B., Jerliu, F. (2016). The Concept of "Modelarium" and its Impact on Creativity and Artistic Education. Review of Artistic Education, Vol. (14), Is. 1. 2017. DOI: 10.1515/rae-2017-0030

22. Bajçinovci, B., Jerliu, F. (2017). Impact on pollution and Urban liveability Abandoned Quarries. Pollution Research, Vol. (36), Is.1: 23-28.

23. Bajçinovci, B., Bajçinovci, U., B. Q. Bajçinovci. (2017). Aloft Metabolism: A Juncture of Architecture Future Design. European Journal of Technology and Design, Vol. (5), Is. 1: 14-19. DOI: 10.13187/ejtd.2017.1.14

24. Bajçinovci, B. (2017). Sustainable Architectural Design - Principles - in the Albanian Language. JOSHA, Journal of Science, Humanities and Arts. Volume: 4 Issue: 3, Freiburg Germany. DOI: 10.17160/josha.4.3.306

25. Bajçinovci, B. (2017). Airports - Planning and Design- in the Albanian Language. JOSHA, Journal of Science, Humanities and Arts. Volume: 4 Issue: 3, Freiburg Germany. DOI: 10.17160/josha.4.3.309

26. Bajçinovci, B. (2017). Commercial Hybrid Buildings - Planning and Design- in the Albanian Language. JOSHA, Journal of Science, Humanities and Arts. Volume: 4 Issue: 3, Freiburg Germany. DOI: 10.17160/josha.4.3.307

27. Bajçinovci, B. (2017). Hotels - Design Principles - in the Albanian Language. JOSHA, Journal of Science, Humanities and Arts. Volume: 4 Issue: 3, Freiburg Germany. DOI: 10.17160/josha.4.3.312

28. Bajçinovci, B. (2017). Industrial Complexes - part 1, Planning and Design - in the Albanian Language. Unpublished, part of the Project: Industrial Complexes - Planning and Design - in the Albanian Language.

ResearchGate, DOI: 10.13140/RG.2.2.23049.13923, DOI: 10.13140/RG.2.2.29969.74082, DOI: 10.13140/RG.2.2.33639.75686 DOI: 10.13140/RG.2.2.14293.52965, DOI: 10.13140/RG.2.2.27805.41441

29. Bajçinovci, B. (2017). Industrial Complexes - part 2, Planning and Design - in the Albanian Language. Unpublished, part of the Project: Industrial Complexes - in the Albanian Language. ResearchGate, DOI: 10.13140/RG.2.2.15086.10564

30. Bajçinovci, B. (2017). Variegated Dynamic Functions as a Blend of Architectural Design and Contemporary Integrated Conceptualization. European Journal of Technology and Design, Vol. (5), Is. 2. 2017. DOI: 10.13187/ejtd.2017.2.46

31. Banka evropiane për rindërtim dhe zhvillim. Strategji për Kosovën. 2013.

32. Birkby, J. (2016). Vertical Farming. NCAT. A program of the National Center for Appropriate Technology.

33. CAA. (2006). An Architect's Guide to Designing for Sustainability. Edgware. UK:Commonwealth Association of Architects. 
34. Commission. EACI. Brussels, Belgium:Executive Agency for Competitiveness and Innovation. 6.

35. Clayton, S., Opotow, S.(2003). Identity and the Natural Environment, The Psychological Significance of Nature. London, UK : MIT Press.

36. Corbusier, L. (1989). Towards a new architecture. Oxford: Butterworth Architecture.

37. Degen, M. M.(2008). Sensing Cities. Rgeneration public life in Barcelona and Manchester. London, UK. New York. USA : Routledge. Tailor \& Francis Group.

38. Dhankhar, S. S. (2010). Environmental Studies. CSS HAU. Hisar.Dept. Agrometeorology: Agricultural University. 28.

39. Drejt zonës evropiane të sigurisë rrugore: orientimi i politikave për siguri rrugore 2011-2020 . COM82010, 389 final, 20.7.2010.

40. Downton, P. (2009). Architecture and Cities for a Changing Climate. Colligwood, Australia:Springer.CSIRO Publishing.

41. Ed. C, Gallo., M, Sala., A.M.M, Sayigh. (Eds). (1988). Architecture: Comfort and Energy. Elsevier.

42. Ed. Banister D.(Eds).(2005). Transport and Urban Development. London.UK: Taylor \& Francis. E \& FN Spon, an imprint of Chapman \& Hall.

43. Ed. Clayton, S., Opotow, S. (Eds).(2003). Identity and the Natural Environment, The Psychological Significance of Nature. London: MIT Press.

44. Ed. Quatman. W., Dhar, R.(Eds).(2003). The Architect's Guide to Design-Build Services. American Institute of Architects. New Jersey \& Canada: John Wiley \& Sons. Inc.

45. Ed. S. William et al..(Eds).(2005). Understanding the Global Dimensions of Health. New York, NY: Springer.

46. Ed. Wilson, A.(Eds).(2001). Greening Federal Facilities., Brattleboro, Vermont: U.S. Department of Energy.

47. EU. (2004). Architect's Council of Europe. Architecture and Quality of Life, Bruxelles, Belgium: EU.

48. Evans S. D.; Schmalensee, R.(2007). Catalyst Code: The Strategies Behind the World's Most Dynamic Companies, Harvard: Harvard Business School Press.

49. Forrester, J. 1969. Urban Dynamics. Pegasus Communications, Inc.

50. Forrester, J. 1979. World Dynamics. Productivity Pr, 2 ed.

51. Gallo, C., sala, M., Sayigh. M.(Eds).(1998). Architecture : Comfort and Energy. Oxford, UK : Elsevier.

52. Hadorn, H. G. et al.(2008). The Handbook of Transdisciplinary Research. Zurich.Switzerland : Springer.

53. Hadrović, Ahmet. (2008). Bioclimatic Architecture: Searching for the Path to Haven. Booksurge Publishing: Amazon. com.

54. Highmore, B. T.(2010)Ordinary Lives: Studies in the Everyday.London, UK. New York. USA : Routledge. Tailor \& Francis Group.

55. Ibrahim, R., Fruchter,. R., Sharif, R. (2007, November). International Journal of Architectural Research. Framework for a cross-border transdisciplinary design studio education., 100(03).

56. I. Krasniqi, G. Latifi. (1982). Teknika e tensioneve te larta. FET, Universiteti i Prishtinës.

57. Kargon, R.,Molella, A.(2008).Invented Edens. Invented-Cities of the Twentieth Century. Cambridge, Massachusetts : Massachusetts Institute of Technology. 
58. Krasniqi, Fejzullah. Selimaj, R., Malsiu, I.(2004). Instalimet Makinerike. Universiteti i Prishtinës.

59. Krasniqi, Fejzullah.(2000). Ngrohja dhe klimatizimi-II. Universiteti i Prishtinës.

60. Kwok G.A. et al.(2007). Environmental strategies for schematic design. Oxford. UK : Elsevier.

61. Lawson B.(2005). How Designers Think. Oxford. UK :Elsevier.

62. Lebel J.(2003). Health, An Ecosystem Aproach. Canada : IDRC.

63. Lee, G., Sacks, R., and Eastman, C. M. (2006). Specifying parametric building object behavior (BOB)for a building information modeling system. Automation in Construction, 15(6), pp.758-776.

64. LEED. (2011). U.S. Green Building Council, standard certificates : USA.

65. Mallgrave, F. H.(2010). The Architect's Brain : Neuroscience, Creativity, and Architecture. Chichester, West Sussex, UK : Wiley Blackwell, Wiley \& Sons,

66. Margolis, L., M., Robinson, A.(2007). Living Systems : InnovatIve MaterIals and technologIes for landscape archItecture. Berlin, Germany:Birkhäuser Verlag AG.

67. Mega, P. V.(2010). Sustainable Cities for the Third Millennium: The Odyssey of Urban Excellence. New York, Dordrecht, Heidelberg, London : Springer.

68. Meijer, F., Visscher, H., Sheridan L.(2002). Building regulations in Europe. I. Nederlands :Delft Uni. pp. 6-188.

69. Ministria e Energjisë dhe e Minierave, (2008). Raport

70. MMPH. Raport për gjendjen e ajrit. 2012.

71. OECD (2010), Cities and Climate Change. Paris, France :OECD Publishing.

72. OGC, CABE,.(2002). Improving Standards of Design: in the Procurement of Public Buildings. London,UK:OGC. 24.

73. OPR. (2007). ASHRAE.Energy Efficiency and Environmental Sustainability. ASHRAE Standard 90.1-2004. Atlanta, USA :ASHRAE.

74. Orr W. D. (2002). The Nature of Design. Oxford, UK :Oxford Uni. Press.

75. Plani Global i dekadës së strategjisë së sigurisë rrugore 2011-2020, e shpallur nga Asambleja e Përgjithshme e Kombeve të Bashkuara me 2.3.2010

76. Piotrowski, A.(2011). Archirecture of Thought. Minneapolis, USA : University of Minnesota Press.

77. Projekti PUP, Prishtinë. (1987). Projeksioni Prishtinës 2000.

78. Pushka, A. (2004). "Statistikat vitale të kohës më të re", ESK. Prishtinë.

79. Politika evropiane e transportit per 2010: Koha te vendosim . COM(2001) 370 final, 12.10. 2001.

80. Programi evropian për siguri rrugore - Përgjysmimi i numrit të viktimave nga aksidentet rrugore deri me 2010 ne Bashkimin Evropian: Pergjegjesi e perbashket. COM (2003) 311 final, 2.6. 2003.

81. RKS. Qeveria. Strategjia Sektoriale dhe Transportit Multimodal 2015-2025 dhe Plan i veprimit 5 vjeqar. 2015.

82. RKS. Qeveria. Ministria e Infrastrukturës. 2015, v1.6. Strategjia e Sigurisë Rrugore dhe Plani i Veprimit në Kosovë

83. Road Transport, 2012. European Union. Luxembourg: Publications Office of the European Union, 2012.

84. Samuelsson, L. (2008). The moral status of nature. Umeå,Sweden : Umeå University.

85. Shedroff, N.(2009). Design Is the Problem, The Future of Design Must be Sustainable. Brooklyn, NY. USA : Rosenfeld Media. 
86. Statistikat dhe analizat e aksidenteve të komunikacionit në periudhën 2013 2014, Drejtoria e Komunikacionit, Policia e Kosovës

87. Smuts, J. (1927). Holism and Evolution. London, UK: McMillan and Co Limited.

88. UN. Habitat: World Cities Report, 2016.

89. UN, DESA. UN. Habitat: Living Planet Report, 2015

90. WHO, World Health Organization. (2009). Global status report on road safety, time for action. Printed in Switzerland.

\section{(อ Prof.Ass.Dr. Bujar Bajçinovci 2017}

